\title{
THE RISE AND FALL OF RELIGIOUS FREEDOM IN GONSTITUTIONAL DISCOURSE
}

\section{STEVEN D. SMITH†}

The thesis of this Article can be succinctly stated: our constitutional commitment to religious freedom contains a fatal internal flaw-a propensity toward self-cancellation. This internal flaw has manifested itself in our recent constitutional history. The intelligent constitutional commitment to religious freedom that once existed in this country has deteriorated, ${ }^{1}$ and this deterioration is due, in significant measure, not to a decline in religiosity in either the general or the legal culture, but rather to the self-negating quality of the commitment itself.

This self-negating propensity stems from the paradoxical relationship between religious freedom's historical justification and its current interpretation. The principal historical justification for our constitutional commitment to religious freedom was a religious rationale. $^{2}$ The justification relied upon religious premises and worked within a religious world view. ${ }^{3}$ Moreover, quite apart from its historical significance, the religious justification is also the most satisfying, and perhaps the only adequate justification for a special constitutional commitment to religious liberty. Today, however, religious freedom, at least as it has come to be understood, forbids governmental reliance upon religious justifications as a basis for public policies or decisions. ${ }^{4}$ Therein lies the paradox-our constitutional commitment to religious freedom undermines its own foundation; it cancels itself out by precluding government from recognizing and acting upon the principal justification supporting that commitment.

If correct, the thesis that religious liberty is self-negating will explain a good deal. It is by now notorious that legal doctrines and

† Professor of Law, University of Colorado. I thank Janet Burton, Rick Collins, Cole Durham, Fred Gedicks, Jim Gordon, Julian Johnson, Bill Marshall, Oscar Miller, Chris Mueller, Bob Nagel, Gene Nichol, and Kevin Reitz for valuable comments on earlier drafts of this Article. Parts of the Article were presented in the Austin W. Scott, Jr. Lecture at the University of Colorado. I received numerous helpful comments, questions, and objections from persons who attended the lecture.

${ }^{1}$ See infra part $\mathrm{V}$.

2 See infra part I.A.

${ }^{3}$ See infra part I.B.

${ }^{4}$ See infra part III.A. 
judicial decisions in the area of religious freedom are in serious disarray. In perhaps no other area of constitutional law have confusion and inconsistency achieved such undisputed sovereignty. ${ }^{5}$ This Article suggests that the internal, self-negating quality of our commitment to religious freedom renders us incapable of interpreting and applying that commitment in a coherent fashion.

In addition to doctrinal confusion, the law in this area has lately exhibited a marked insensitivity to the value of what it is ostensibly designed to protect-the freedom of citizens to believe and practice their religion. This insensitivity is especially evident in recent decisions under the Free Exercise Clause, but it is manifest in other areas as well. ${ }^{6}$ It would be easy to blame this relaxation of protection on a growing secularism that marginalizes religious belief and practice. But that easy explanation is inconsistent with survey and sociological evidence indicating that religious belief has not declined in this country. ${ }^{7}$ I will argue that the waning of our constitutional commitment to religious liberty need not be explained by any deterioration in religious commitment. Rather, the phenomenon results from the self-canceling character of the commitment itself.

Thus, the thesis of this Article has considerable explanatory value-if, that is, the thesis is not implausible. But that is an important reservation. Legal disputes raising issues of religious freedom are as numerous today as ever, and they often elicit judicial pronouncements paying respect to the importance of religious freedom in our constitutional scheme. These pronouncements may seem to contradict the contention that our commitment to religious freedom has dwindled.

I can offer no quick answer to this objection, but its force can perhaps be blunted by a preliminary clarification of what I will argue. My contention that there is at present no intelligent constitutional commitment to religious freedom should not be

${ }^{5}$ See, e.g., Carl H. Esbeck, The Lemon Test: Should It Be Retained, Reformulated or Rejected?, 4 Notre Dame J.L. ETHICs \& PUB. Pol'y 513, 543 (1990) ("It is hard to think of a contemporary legal doctrine that is as besieged from all quarters as [current Establishment Clause doctrine]." ); Stanley Ingber, Religion or Ideology: $A$ Needed Clarification of the Religion Clouses, 41 STAN. L. REV. 233, 233 (1989) (observing that "few areas of constitutional law lie in greater confusion"). For further discussion of the prevailing incoherence, see infra part V.A.

${ }^{6}$ For a gloomy assessment of recent developments, see Douglas Laycock, The Remnants of Free Exercise, 1990 SUP. CT. REV. 1 and infra part V.B.

${ }^{7}$ See infra part II.B. 
understood to assert more than it actually claims. For example, in denying that there is an "intelligent" constitutional commitment to religious freedom, I acknowledge that there may be a commitment that is merely traditional or instinctual, ${ }^{8}$ but that is not based on consciously understood and currently believable grounds. In addition, a constitutional commitment to religious freedom is not the same as actual religious freedom; either might exist without the other. ${ }^{9}$ Hence, in arguing that there is no intelligent constitutional commitment to religious freedom I do not deny that a considerable measure of actual religious freedom continues to exist in this country.

Furthermore, I am speaking about a specific constitutional commitment to religious freedom. It is possible that there is a commitment to other kinds of freedom-general personal autonomy, perhaps, or freedom of belief-and that religious conduct or belief may sometimes fall within these other categories. ${ }^{10}$ One might hold, for example, that a person is free to be a pantheist simply because pantheism is a belief and citizens have a constitutional right to believe whatever they choose. The fact that pantheism is a religious belief would be irrelevant to this claim. I do not deny the existence of constitutional commitments to various kinds of freedoms that may sometimes happen to protect religious beliefs or practices. I contend only that there was once an intelligent constitutional commitment to religious freedom specifically, and that this commitment has seriously deteriorated.

That deterioration is due in part, I will argue, to the conceptual paradox that has caused our constitutional commitment to religious freedom to cancel itself out. This contention also warrants preliminary clarification. First, I will focus on one intellectual strand in a complex historical and cultural tapestry. The strand I

${ }^{8}$ This statement is not meant to disparage an instinctual commitment to religious freedom. An instinctual commitment may be better than none at all. One might even argue that a purely instinctual commitment is more secure than a conscious and rational one, although the analysis presented in this Article, particularly in part IV.H., questions that proposition.

${ }^{9}$ For example, a legal community might have a commitment to religious freedom yet lack the will or the resources to carry out that commitment. Conversely, a legal community might have no commitment to religious freedom, but for other reasons (perhaps because the community is generally indifferent to religion or adheres to a policy of general laissez faire) religious freedom might nonetheless flourish.

${ }^{10}$ See generally William P. Marshall, Solving the Free Exercise Dilemma: Free Exercise as Expression, 67 MINN. L. REV. 545 (1983) (arguing for protection of free exercise rights through the Free Speech Clause). 
have chosen to examine is a central one, but I do not mean to imply that it represents the whole picture. Second, even with respect to the intellectual strand I am considering, I do not mean to suggest there is anything compulsory or logically inescapable about the conceptual paradox. We-the constitutional community, including especially the Supreme Court and those who criticize or prescribe to it-might have avoided the paradox by thinking more carefully about the meaning of religious freedom. Specifically, we might have avoided the paradox by declining to adopt an interpretation holding that governmental reliance upon religious justifications is incompatible with a commitment to religious freedom. It is even possible that we still can dissolve the paradox and escape the malaise that currently afflicts constitutional musings on the matter of religious freedom (although at the moment I see little reason for optimism on this score). The paradox, in short, describes the course our thinking about religious freedom has taken, not a course that our thinking was or is compelled to take.

Part I discusses the religious justification and argues for the central importance of that justification in generating a commitment to religious freedom in the founding period. Part II describes the disappearance of the religious justification from contemporary constitutional discourse. It also considers and rejects the view that would explain this disappearance by an assumption that secularization has deprived the religious justification's premises of their plausibility. Part III offers a better explanation: the religious justification has been rendered inadmissible in public discussion by the prevailing interpretation of what religious freedom means. In this way, our commitment to religious freedom has nullified its own historical justification.

Part IV considers possible nonreligious replacements for the religious justification. It concludes that the most common nonreligious rationales for religious freedom are vulnerable to serious objections and, thus, are probably inadequate to sustain a strong constitutional commitment. Part V examines the consequences of this failure of justification, arguing that it has produced massive incoherence in religion clause jurisprudence and a withdrawal of judicial protection for religious freedom. 


\section{THE RISE OF RELIGIOUS FREEDOM}

Thomas Jefferson's description of "the constitutional freedom of religion" as "the most inalienable and sacred of all human rights" ${ }^{11}$ reflects, more or less accurately, an understanding that has prevailed during much of our history. ${ }^{12}$ That understanding generates a serious problem: what is the justification for affording special constitutional protection to religious freedom? Our constitutional scheme, of course, is vitally concerned with human freedom generally. ${ }^{13}$ However, most aspects of that freedom receive only generic protection through provisions designed to ensure, for example, democratic government and due process of law. Yet a few freedoms have historically been singled out and elevated to special constitutional status. Religious freedom has been one of these. ${ }^{14}$ The question is, why? How did religion, as opposed to other candidates for special protection, such as economic interests, come to achieve distinct recognition as a centerpiece in our constitutional system ? $^{15}$

11 Thomas Jefferson, Freedom of Religion at the University of Virginia, in THE COMPLETE JeFFERSON 957, 958 (Saul K. Padover ed., 1969).

${ }^{12}$ Mary Ann Glendon asserts that Americans generally rank religious freedom as the most important of our constitutional rights, ahead of freedom of speech, but that the legal academy and the "knowledge class" do not give it the same priority. See Mary Ann Glendon, Law, Communities, and the Religious Freedom Provisions of the Constitution, Address to the Bicentennial Conference on the Religion Clauses (May $30,1991)$ (transcript on file with author).

${ }^{13}$ The Preamble to the Constitution states that one of its major purposes is to "secure the Blessings of Liberty to ourselves and our Posterity." U.S. CoNST. pmbl.

14 See ARLIN M. ADAMS \& CharLes J. EMmERICH, A Nation DEDICATED to RELigious LiberTy: THE CONSTITUTIONAL HeRTTAge OF THE RELIGION ClaUSES 91 (1990) ("[T]he Founders granted religion a special status in the Constitution. This status derived from a conviction that religious exercise, as opposed to other personal and social forces, needed and deserved unique treatment."); LAURENCE H. TRIBE, AMERICAN CONSTITUTIONAL LAW $\$ 14-7$, at 1189 (2d ed. 1988) ("The Framers ... clearly envisioned religion as something special; they enacted that vision into law by guaranteeing the free exercise of religion but not, say, of philosophy or science."); $f f$. Paul J. Weber, Concluding Reflections, in EQUAL SEPARATION: UNDERSTANDING THE RELIGION ClAUSES OF THE FIRST AMENDMENT 149, 150 (Paul J. Weber ed., 1990) [hereinafter EQUAL SEPARATION] (suggesting that "the freedom to exercise one's religion is an independent, substantive right under the Constitution and ... this religious liberty can justly be called 'the first freedom'").

${ }^{15}$ For a discussion of the special place of religion as opposed to economic interests in the constitutional scheme, see Michael E. Smith, The Special Place of Religion in the Constitution, 1983 Sup. CT. REv. 83, 83-84. 


\section{A. The Religious Justification}

As a historical matter, the answer to that question has often taken the form of a religious justification. ${ }^{16}$ In current discourse, however, this explanation is less familiar, and may even seem counterintuitive. Consequently, it will be useful to spell out the religious justification before considering its role in our constitutional history.

The religious justification has been stated in various ways and with varying degrees of elaboration. The essential argument can be presented in the form of two claims: the priority claim and the voluntariness claim. The priority claim asserts that "religious goods" - that is, the distinctive goods, benefits, or blessings toward which religious beliefs and practices are directed-are more valuable or more important than most or perhaps all other human goods. The idea is expressed in The Bible: "For what is a man profited if he gains the whole world, and loses his own soul?"17 The priority claim can also be made in more deontological terms: religious duties take precedence over other duties, including nonreligious legal or social duties.

The voluntariness claim asserts that religious goods or duties by their nature entail freedom of choice. ${ }^{18}$ It is futile, at least from a religious perspective, to force a person to profess a religious creed or conform to a religious practice because compulsory faith lacks religious efficacy. Compelled religion, the voluntariness claim

${ }^{16}$ Although I use the singular here to refer to the religious justification that is the subject of this Article, there are other arguments justifying religious freedom that are religious in nature. For example, Madison's Memorial and Remonstrance contains several arguments that are religious in character. See James Madison, Memorial and Remonstrance Against Religious Assessments, reprinted in THE SUPREME COURT ON CHURCH AND STATE 18, 18-23 (Robert S. Alley ed., 1988); infra notes 46-48.

17 Matthew 16:26.

${ }^{18}$ Freedom, in this context, means freedom from external governmental coercion. Religious believers have historically disagreed about whether the will is free and whether humans can contribute through their own choices to their salvation. See David C. Williams \& Susan H. Williams, Volitionalism and Religious Liberty, 76 CORNELL L. REV. 769, 852-74 (1991). These theological disagreements have not prevented believers of various sorts from agreeing on the inefficacy, or even the impossibility, of religious belief and practice compelled by government. 
insists, is a contradiction in terms; ${ }^{19}$ in Roger Williams's pungent expression, "forced worship stinks in God's nostrils." 20

Taken together, but only when taken together, these claims can support a constitutional commitment to religious freedom. If religious goods or duties take precedence over other goods or duties, as the priority claim asserts, then the state should not interfere with religion in the interest of other matters that are necessarily less weighty. Taken by itself, however, the priority claim calls upon government to respect religion, but not necessarily religious freedom. On the contrary, if religion is the source of supremely important goods or duties, then it might seem that a government concerned for the welfare of its citizens should require them to accept such goods or to perform such duties. ${ }^{21}$ After all, governments commonly oblige citizens with compulsory education laws, mandatory social security withholding, seat belt requirements, and substance abuse prohibitions, at least in part on the ground that such compulsion is good even for those citizens who fail to appreciate the wisdom in these measures. Why should government impose these mundane benefits on its citizens and at the same time neglect their incomparably greater interest in the salvation of their souls? It is the voluntariness claim with its insistence upon the futility of compulsory religion that justifies a public commitment not just to religion, but to religious freedom.

Just as the religious justification for religious freedom cannot rest on the priority claim alone, however, neither can it rely solely on the voluntariness claim. To be sure, compulsory religion may be futile and even self-contradictory. This realization should discourage government from interfering with citizens' religious beliefs and practices in order to secure religious benefits for these citizens. ${ }^{22}$

19 This argument was a central theme in John Locke's A Letter Concerning Toleration, which strongly influenced the thinking of many Americans, including Jefferson and Madison. See Lance Banning, James Madison, the Statute for Religious Freedom, and the Crisis of Republican Convictions, in THE VIRGINIA STATUTE FOR RELIGIOUS FREEDOM: ITS EVOLUTION AND CONSEQUENCES IN AMERICAN HISTORY 109, 118 (Merrill D. Peterson \& Robert C. Vaughan eds., 1988) [hereinafter VIRGINIA STATUTE].

${ }^{20}$ PATRICIA U. BONOMI, UNDER THE COPE OF HEAVEN: RELIGION, SOCIETY, AND POLITICS IN COLONIAL AMERICA 35 (1986) (quoting Roger Williams).

${ }^{21}$ Augustine argued to this effect. See Letter CLXXIII from Augustine to Donatus (A.D. 416), in CHRISTIAN Social TEACHINGS 79-83 (George W. Forell ed., 1966).

22 Government might, however, compel outward adherence to religion not in order to benefit the persons so compelled, but rather to protect the faith of weak believers who might be disturbed or shaken by the deviations of others. Aquinas justified religious coercion in this way. See JOHN T. NOONAN, JR., THE BELIEVER AND 
But the discussion need not end there. For one thing, government may have nonreligious reasons for regulating practices that happen to be religious. Government may prohibit the use of peyote, for example, not because of any religious objection to the ceremonies in which peyote is essential, but rather because peyote happens to be on a list physically harmful drugs. ${ }^{23}$ If government has nonreligious reasons for regulating religious practices, the voluntariness claim gives no reason for restraint. Only the priority claim provides such a reason.

In sum, the priority and voluntariness claims together form a cogent justification for extending special legal protection to religious freedom. The priority claim suggests that government should respect religion and avoid subordinating religious goods and duties in favor of secular concerns. The voluntariness claim suggests that the way in which government should respect religion is by securing religious freedom.

Of course, this justification will be effective only if government finds the priority and voluntariness claims persuasive. But that observation raises difficult questions: Are these claims persuasive? Are they even the kind of claims that government is competent to accept or reject?

\section{B. The Centrality of the Religious Justification in the Founding Period}

It seems obvious today that the religious justification for religious freedom is at least controversial. An agnostic, for example, is not likely to agree that distinctively spiritual or religious goods and duties are supremely important; he may regard such ostensible goods and duties as illusory or even contemptible. ${ }^{24}$ For present purposes, however, the critical point is that although the religious justification is not universally persuasive, that justification carried considerable weight with Americans of the founding generation. ${ }^{25}$

THE POWERS THAT ARE 36-41 (1987) (reprinting and discussing pertinent portions of Summa Theologica).

${ }^{23}$ See Employment Div., Dep't of Human Resources v. Smith, 494 U.S. 872 (1990). This decision is discussed infra part V.B.

${ }^{24}$ See JAMES TURNER, WITHOUT GOD, WITHOUT CREED: THE ORIGINS OF UNBELIEF IN AMERICA 203-25 (1985) (explaining the nineteenth-century agnostics' view that religious belief was immoral).

${ }^{25}$ Cf. PAUL G. KAUPER, RELIGION AND THE Constitution 22-23 (1964) (explaining the classical Christian belief, which motivated American dedication to religious 
Its influence is hardly surprising given the pervasively religious world view then prevailing. Although historians disagree about whether the establishment of the Republic, and in particular the adoption of constitutional protections for religious freedom, should be viewed primarily as the products of religious or secular thinking, ${ }^{26}$ one can safely make two generalizations about Americans of the founding period. First, the founding generation was deeply and pervasively influenced by Protestant thought and practice. ${ }^{27}$ The religious justification for religious freedom has deep roots in Protestant thought, with its emphasis upon the distinction between the "two kingdoms." Second, even those Americans like Jefferson, who departed from Protestant orthodoxy under the influence of the Enlightenment and who were accordingly sometimes regarded by their more pious contemporaries as "infidels" or even

freedom in the founding period, that "faith is not to be achieved by coercive power but by the working of the spirit of God").

${ }^{26}$ Bernard Bailyn's classic account of the American founding stresses its secular qualities and gives little emphasis to religious elements and influences. See BERNARD BAILYN, THE IDEOLOGICAL ORIGINS OF THE AMERICAN REVOLUTION (1967). For a more recent essay arguing that the Founders were in essence "secular humanists," see John M. Murrin, Religion and Politics in America from the First Settlements to the Civil War, in RELIGION AND AMERICAN POLITICS FROM THE COLONIAL PERIOD TO THE 1980s, at 19, 30-33 (Mark A. Noll ed., 1990) [hereinafter RELIGION AND AMERICAN PoLmics]. For studies underscoring the religious character of the founding, see ELLIS SANDOZ, A Government of LaWs: POLITICAL THEORY, Religion, and THE AMERICAN FOUNDING (1990); Ruth $\mathrm{H}$. Bloch, Religion and Ideological Change in the American Revolution, in RELIGION AND AMERICAN POLITICS, supra, at 44. For a historical study that attempts to split the difference, see William L. Miller, The Moral Project of the American Founders, in ARTICLES OF FATTH, ARTICLES OF PEACE: THE RELIGIOUS LIBERTY Clauses AND THE AMERICAN PUBLIC PHLLSOPHY 17 (James D. Hunter \& Os Guinness eds., 1990) [hereinafter ARTICLES OF FAITH].

${ }^{27}$ See, e.g., Thomas J. CuRRY, THE FIRST FREEDOMS: CHURCH AND STATE IN AMERICA TO THE PASSAGE OF THE FIRST AMENDMENT 219 (1986) (noting that in the founding period, "Protestant Christianity thoroughly permeated civil and political life").

${ }^{28}$ The "two kingdoms" are church and civil government:

Luther and Calvin both argued that God had instituted two kingdoms on earth, one spiritual to be administered by the church, and the other temporal to be ruled by a civil sovereign. This dualism was incorporated into the theologies of certain Protestant sects of the late Reformation . . . . In the view of [these sects], unity or alignment of the church with civil government unavoidably corrupted the church and stained the religious conscience of its believers. The only solution that would preserve the religious integrity of the church and its believers was separation of their religious activities of devotion and worship from the political activities of government.

Frederick M. Gedicks, The Religious, the Secular, and the Antithetical, 20 CAP. U. L. REV. 113, 117-18 (1991). 
"atheists," 29 viewed the world in strongly religious terms. ${ }^{30}$ In sum, "in eighteenth-century America-in city, village, and countryside-the idiom of religion penetrated all discourse, underlay all thought, marked all observances, gave meaning to every public and private crisis." 31

In view of this broadly religious framework, it is not surprising that the religious justification for religious freedom had great force in the colonial and founding periods. The argument was eloquently advanced by ministers and religious leaders such as Roger Williams, William Penn, John Leland, and Isaac Backus. ${ }^{32}$ Although conceding this much, however, one common position holds that more "enlightened" and politically powerful advocates of religious freedom such as Madison and Jefferson acted upon a secular rationale. ${ }^{33}$

29 James Turner observes that "[w]hat the orthodox called 'atheism' usually amounted to nothing but a Deistic denial of revealed religion .... If one disregards the expatriate Barlow just before 1800, America does not seem to have harbored a single individual before the nineteenth century who disbelieved in God." TURNER, supra note 24, at 44 .

${ }^{30}$ For a useful discussion of the essentially Christian foundations of Jeffersonian thought, see DANIEL J. BOORSTIN, THE LOST WORLD OF THOMAS JEFFERSON 27-56, 151-66, 243-48 (1948).

31 BONOMI, supra note 20, at 3. Moreover, contrary to the view that religiosity declined in the colonies as the early Puritan approach to life lost its initial vigor, Bonomi sees an "increasing interpenetration of religion and politics" as the eighteenth century progressed. Id. at 8-9. Another writer adds:

[W] may be able to understand [eighteenth-century American] political thought better if we start where they nearly always did, with religion. Men of the late eighteenth century, whether they were Calvinists or Arminians, deists or atheists, seldom thought about any branch of human affairs without referring consciously to some general beliefs about the nature of the universe and man's place in it, and about human nature itself. In this sense Jefferson and Paine were as religious as any New England Congregationalist. The denials and defiances of Enlightenment skeptics and materialists are denials and defiances of religious doctrine, usually religious in their own intent.

HENRY F. MAY, THE ENLIGHTENMENT IN AMERICA at xiii-xiv (1976).

32 For useful overviews, see ADAMS \& EMMERICH, supra note 14, at 21-31, and Michael W. McConnell, The Origins and Historical Understanding of Free Exercise of Religion, 103 HARV. L. REv. 1409, 1437-43, 1445-46 (1990). For a discussion of Isaac Backus's views and his influence in the achievement of religious freedom, see Williams \& Williams, supra note 18 , at 870-74.

${ }^{33}$ See, e.g., Edwin S. Gaustad, Colonial Religion and Liberty of Conscience, in VIRGINIA STATUTE, supra note 19, at 23; Murrin, supra note 26, at 33; John Witte, Jr., The Theology and Politics of the First Amendment Religion Clauses: A Bicentennial Essay, 40 EMORY L.J. 489, 491-97 (1991). 
This view may reflect the interpretation offered in Mark DeWolfe Howe's classic The Garden and the Wilderness. ${ }^{34}$ Howe discussed two competing and historically prominent rationales for religious freedom. One rationale, which Howe associated with Roger Williams, was concerned with protecting the church against the corruptions of politics; Howe called this the "theological" or "evangelical" rationale for church-state separation. ${ }^{35}$ But Howe assumed that "enlightened" statesmen, such as Madison and Jefferson, were primarily seeking to protect politics from intrusions by the church. These statesmen favored religious freedom on the basis of a "political" rationale. ${ }^{36}$ To be sure, a major purpose of Howe's study was to restore the theological justification to its proper place. Thus, he argued that the theological rationale for religious freedom was as influential during the founding period as the political rationale, ${ }^{37}$ and that by refusing to acknowledge that theological theme the modern Supreme Court had produced bad history and bad legal analysis. ${ }^{38}$ Nonetheless, Howe's attribution of a "political" rationale to the more politically influential proponents of religious freedom may seem to support an interpretation that sees the religious justification as secondary in the achievement of a constitutional commitment to religious freedom.

Howe's interpretation is apt to mislead, however, if it is understood as depicting our constitutional religious freedom to be the result of two competing rationales, one religious and one secular. ${ }^{39}$ This understanding reflects a problem described by

${ }^{34}$ MARK D. HOWE, THE GARDEN AND THE WILDERNESS: RELIGION AND GOVERNMENT IN AMERICAN CONSTITUTIONAL HISTORY (1965). Though perhaps not all critics would be quite so generous, the status of Howe's work is reflected in the judgment of one constitutional scholar, expressed more than twenty years after the book was published: "[Howe's study] remains by far the best piece of scholarship in the field of church and state." Tom Gerety, Legal Gardening: Mark DeWolfe Howe on Church and State: A Retrospective Essay, 38 STAN. L. REv. 595, 596 (1986).

${ }^{35}$ See Howe, supra note 34 , at 6-10.

${ }^{36}$ See id. at 1-2, 6-7.

${ }^{37}$ Howe's overall interpretation stressed that "men of the eighteenth century who demanded a constitutional proscription of laws relating to religion did so because of the deep conviction that the realm of spirit lay beyond the reach of government." Id. at 17-18.

${ }^{38}$ See id. at 4-19. Howe contended that "[b]y superficial and purposive interpretations of the past, the Court has dishonored the arts of the historian and degraded the talents of the lawyer." Id. at 4.

${ }^{39}$ It is not clear that Howe meant his thesis to be understood in this way. His purpose was not to challenge the modern understanding, which views the Jeffersonian rationale as "secular." Even so, he noted that the secular quality of Jefferson's thinking had "possibly [been] exaggerated." Id. at 2. 
Howe himself as "the unnoted change in the meaning of familiar words and the consequent transformation of controlling concepts." 40 Ruth Bloch has observed that "[a] connection between what we normally distinguish as religious or secular was embedded in the very meaning of Revolutionary language itself." ${ }^{\text {41 }}$ Thus, the contrast between the Williams and the Jeffersonian positions is more accurately described as a difference in kinds or styles of religious thinking, not as a conflict between "religious" and "secular" thought in the contemporary sense of those terms. The "religious" style was specifically biblical and evangelical in character; the "secular" style, grounded in "natural religion," was more generic and philosophical in its religious orientation. But both rationales were centrally dependent upon religious, indeed theistic, assumptions.

This religious quality is discernible in the post-Revolution controversy in Virginia that provoked Madison's famous Memorial and Remonstrance and produced both the defeat of the Assessments Bill for subsidizing Christian ministers and the adoption of Jefferson's Virginia Act for Religious Freedom. ${ }^{42}$ Arguments for freedom of religion were expressed in countless citizen petitionsthe assessments controversy generated thousands. Rhys Isaac groups these petitions into two categories. One kind, reflecting the thinking and rhetoric of the Separatist Baptists, argued that the Holy Ghost was sufficient to maintain and direct the church without governmental assistance and that state-supported religion was contrary to "the spirit of the Gospel. ${ }^{n 43}$ The other type, exhibiting a Presbyterian viewpoint, "confin[ed] themselves largely to rational, secular arguments and to the language of natural religion, rather than employing a rhetoric that invoked Scriptural revelation and the powers of divine grace." 44

Isaac's description of these arguments as "rational" and "secular" must be understood in the historical context which he is discussing.

${ }^{40} \mathrm{Id}$. at 154 .

${ }^{41}$ Bloch, supra note 26, at 51; seg also Harry S. Stout, Rhetoric and Reality in The Early Republic: The Case of the Federalist Clergy, in RELIGION AND AMERICAN POLITICS, supra note 26 , at 62,65 ("Differences that would radically divide 'secular humanists' and 'evangelicals' . . . were, in 1787, still more potential than real.").

42 On the historical significance of the Virginia Act, see infra text accompanying note 183 .

${ }^{43}$ Rhys Isaac, "The Rage of Malice of the Old Serpent Devil": The Dissenters and the Making and Remaking of the Virginia Statute for Religious Freedom, in VIRGINIA STATUTE, supra note 19 , at $139,150-51$.

${ }^{44} \mathrm{Id}$. at 150 . 
By contrast to the Baptist petitions, which were filled with biblical language and appeals to the Christian creed, the Presbyterian petitions may indeed have seemed "secular." To modern eyes, however, these arguments look distinctly religious. Madison's Memorial and Remonstrance, which Isaac views as an expression of the "Presbyterian" or "secular" position, ${ }^{45}$ clearly articulated the religious justification for religious freedom. Madison's primary argument asserted:

It is the duty of every man to render to the Creator such homage, and such only, as he believes to be acceptable to him. This duty is precedent both in order of time and degree of obligation, to the claims of Civil Society. Before any man can be considered as a member of Civil Society, he must be considered as a subject of the Governor of the Universe: And if a member of Civil Society, who enters into any subordinate Association, must always do it with a reservation of his duty to the general authority; much more must every man who becomes a member of any particular Civil Society, do it with a saving of his allegiance to the Universal Sovereign. We maintain therefore that in matters of Religion, no man's right is abridged by the institution of Civil Society, and that Religion is wholly exempt from its cognizance. ${ }^{46}$

In this argument, Madison used the language of social contract and obligation to assert the priority of religious duties over other duties. If our obligation to the Creator precedes our assumption of the obligations imposed by civil society, then the latter obligations are subject or subordinate to our religious duties. In the first sentence of the preceding quotation Madison also expressly asserted that religion is essentially voluntary in nature. ${ }^{47}$ Thus, Madison forcefully advanced both the priority and voluntariness claims as part of a religious justification for religious freedom. ${ }^{48}$

45 See id. at 149-50.

${ }^{46}$ Madison, supra note 16, at 18-19 (emphasis added).

47 The voluntariness claim is also explicit in Madison's assertion that "we hold it for a fundamental and undeniable truth, "that Religion or the duty which we owe to our Creator and the Manner of discharging it, can be directed only by reason and conviction, not by force or violence." Id. at 18 .

${ }^{48}$ The religious justification occupied first position in the Memorial and Remonstrance and was the principal argument for the claim that freedom of religion is an "unalienable" right. However, Madison also advanced a variety of other arguments. Some of these assumed or built upon the religious justification. Several others, which did not necessarily rest upon that assumption, were nonetheless religious in character. For example, Madison argued that the use of religion "as an engine of Civil policy" amounted to "an unhallowed perversion of the means of salvation." Id. at 20. He also contended that state support is bad for the church, producing "pride and indolence in the Clergy; ignorance and servility in the laity; in 
The religious justification offered by Madison echoed similar arguments that Jefferson had advanced in the Virginia legislature. ${ }^{49} \mathrm{~A}$ religious argument was likewise put forward-albeit without comparable elaboration-in Jefferson's Virginia Act for Religious Freedom. The Act's preamble began with the declaration that "Almighty God hath created the mind free," and it proceeded to assert that any form of compelled religion represents "a departure from the plan of the Holy Author of our religion." 50 Thus, the religious justification for religious freedom occupied a central place in the arguments not only of ministers and religious leaders, but also of political leaders such as Madison and Jefferson. ${ }^{51}$

In emphasizing the importance of the religious justification, I do not suggest that the achievement of religious freedom in the United States was a simple affair in which the Founders reflected upon the priority and the essentially voluntary character of religion, discovered that Christian beliefs required religious freedom, and then promptly acted upon this discovery by adopting the First Amendment and similar provisions at the state level. History is never that neat. In the first place, religious arguments obviously did not all run in one direction; opponents of religious freedom could offer religious arguments for their position. ${ }^{52}$ In addition, proponents of religious freedom naturally did not place their entire reliance

both, superstition, bigotry, and persecution." Id. at 21. Further, Madison argued that the effect of an established church would be to discourage immigration by persons not belonging to that church, and that this would be unfortunate because " $[t]$ he first wish of those who enjoy this precious gift [of Christianity], ought to be that it may be imparted to the whole race of mankind." Id. at 23.

${ }^{49}$ See Thomas E. Buckley, The Political Theology of Thomas Jefferson, in VIRGINIA STATUTE, supra note 19 , at $75,85-86$.

50 Virginia Act for Religious Freedom, VA. CoDE ANN. § 57-1 (Michie 1986), reprinted in VIRGINIA STATUTE, supra note 19, at xvii. For a helpful discussion of the religious premises and values underlying both the Virginia Act for Religious Freedom and other Jeffersonian legislation, see Daniel L. Dreisbach, Thomas Jefferson and Bills Number 82-86 of the Revision of the Laws of Virginia, 1776-1786: New Light on the Jeffersonian Model of Church-State Relations, 69 N.C. L. REv. 159 (1990).

${ }^{51}$ See Buckley, supra note 49, at 77 (asserting that Jefferson "argued for separation of church and state based on the nature of religion itself, and founded a public policy for the United States on a theology"); see also David Little, Religion and Civil Virtue in America: Jefferson's Statute Reconsidered, in VIRGINIA STATUTE, supra note 19, at 237, 249-51 (discussing important similarities between Madison's and Jefferson's arguments for religious freedom and those of Roger Williams, and their common basis in Christian tradition).

52 See, e.g., John T. Noonan, Jr., "Quota of Imps," in VIRGINIA STATUTE, supra note 19 , at 171, 182-83 (describing arguments of Chief Justice Theophilus Parsons of Massachusetts favoring religious establishment in that state). 
upon a single argument. The religious justification discussed here did occupy a central place in their thinking, but they offered other arguments as well (many of which were also religious in character). ${ }^{53}$

Although the articulation during the founding period of diverse arguments for religious freedom is entirely natural and in no way inconsistent with the present argument, one alternative rationale deserves special notice because in modern constitutional discourse it is sometimes viewed as the historical justification for religious freedom. According to this interpretation, the Framers opted for religious freedom as a way of avoiding the civil turmoil that religion might otherwise bring about, as had been shown by the religious wars in Europe and by the civil wars that divided England in the seventeenth century. ${ }^{54}$ Michael Smith relates that this civil peace rationale is probably the most commonly articulated justification for religious freedom in modern legal discourse. ${ }^{55}$ If correct, this interpretation might suggest that the religious justification was merely peripheral or incidental in the achievement of religious freedom.

Yet while the civil peace rationale probably influenced the founding generation, the contention that it was the historical rationale, or even the primary rationale, seems anachronistic; it likely reflects what in the view of some modern interpreters should have been the Framers' primary rationale, but not what Americans of that period actually regarded as their principal ground for religious freedom. For example, Jefferson recited a number of rationales for religious freedom in the Virginia Act for Religious Freedom, but did not mention the civil peace rationale in an explicit form. ${ }^{56}$ And although he did advance the civil peace rationale for religious freedom in his Notes on Virginia, ${ }^{57}$ other arguments

53 See supra note 48.

${ }^{54}$ See WALTER BERNS, THE FIRST AMENDMENT AND THE FUTURE OF AMERICAN DEMOCRACY 9-10, 27-30 (1976); JOHN C. MURRAY, WE HOLd These TruTHS 56-60 (1960). For a recent student note arguing for this position, see Laura Zwicker, Note, The Politics of Toleration: The Establishment Clause and the Act of Toleration Examined, 66 IND. L.J. 773 (1991).

55 See Smith, supra note 15, at 96; see also Gerard V. Bradley, The No Religious Test Clause and the Constitution of Religious Liberty: A Machine that Has Gone of Itself, 37 CASE W. RES. L. REV. 674, 736-37 (1987).

56 See Virginia Act for Religious Freedom, VA. CODE ANN. \$ 57-1 (Michie 1986), reprinted in VIRGINIA STATUTE, supra note 19, at xvii.

57 See THOMAS JEFFERSON, Notes ON VIRGINIA, in The Life AND SELECTED WRTINGS OF THOMAS JEFFERSON 187 (Adrienne Koch \& William Peden eds., 1944). 
asserting a religious justification, ${ }^{58}$ a libertarian justification, ${ }^{59}$ and a sort of governmental fallibilism-marketplace justification ${ }^{60}$ received both priority of place and greater space in the discussion. Likewise, Madison, in his Memorial and Remonstrance, asserted the civil peace rationale, but that argument was hardly primary; it appeared in the eleventh of fifteen paragraphs offering a variety of justifications for religious freedom. ${ }^{61}$ By contrast, the religious justification was not only the first of Madison's arguments, but also served as the predicate to a number of others.

The marginal role of the civil peace rationale may in part have been the result of its essentially prudential character. Americans of the founding generation were more attracted to arguments that supported natural and inalienable rights, not mere pragmatic policies. ${ }^{62}$ The religious justification could serve that purpose, ${ }^{63}$ but the more practical civil peace rationale could not.

Even more importantly, the civil peace rationale may not have seemed very persuasive to Americans of the founding period. Indeed, to many it may have seemed perversely wrongheaded. At that time the common assumption was that civil peace and social stability were enhanced by the maintenance of a uniform religionan arrangement that religious freedom threatened to upset:

For more than fourteen hundred years ... it was a universal assumption that the stability of the social order and the safety of the state demanded the religious solidarity of all the people in one church. Every responsible thinker, every ecclesiastic, every ruler

Jefferson observed that the experiment with disestablishment in New York and Pennsylvania had led to the flourishing of religion "sufficient to preserve peace and order," and that in those states "harmony is unparalleled, and can be ascribed to nothing but their unbounded tolerance." Id. at 276-77.

58 "The rights of conscience we never submitted, we could not submit. We are answerable for them to our God." Id. at 275.

59 "The legitimate powers of government extend to such acts only as are injurious to others. But it does me no injury for my neighbor to say there are twenty gods, or no God. It neither picks my pocket nor breaks my leg." Id.

${ }^{60} \mathrm{See}$ id. at 275-76.

61 See Madison, supra note 16, at 22.

62 See LeO PFEFFER, CHURCH, StATE, AND FREEDom 101 (1953).

63 The value of the religious justification is suggested in Jefferson's observation: "And can the liberties of a nation be thought secure when we have removed their only firm basis, a conviction in the minds of the people that these liberties are the gift of God?" JEFFERSON, supra note 57, at 278. Cf. Harold J. Berman, Religious Freedom and the Challenge of the Modern State, in ARTICLES OF FAITH, supra note 26, at 40, 53 (describing "Adams's and Madison's conception that religious freedom can only be secure if it is undergirded by religious faith"). 
and statesman who gave the matter any attention, held to this as an axiom. There was no political or social philosophy which did not build upon this assumption. . . [A]ll, with no exceptions other than certain disreputable and "subversive" heretics, believed firmly that religious solidarity in the one recognized church was essential to social and political stability. ${ }^{64}$

This "universal assumption" was perhaps not universally held in this country, but it was common. During the colonial period "it was a 'self-evident' truth that church and state must labor side by side" and " $[t]$ he majority ... knew that society prospered, the state advanced, and the gospel was made secure only as sacred and secular realms coalesced." 65 The seventeenth-century experience with religious toleration in Maryland supported this view. ${ }^{66}$ Marylanders eventually retreated from religious toleration and established the Anglican church because "they had experienced directly the bitter conflict that religious choice could foster. ${ }^{\mathbf{6 7}}$

Against this received wisdom, even "enlightened" statesmen such as Madison and Jefferson looked upon religious freedom as "a great experiment. ${ }^{n 68}$ Hence, it is not surprising that their arguments for religious freedom did not emphasize the experimental and highly controversial civil peace rationale, but instead stressed that religious freedom was actually required by the very religious beliefs that most Americans shared.

There is an important qualification of the thesis here presented. The discussion has focused upon intellectual justifications for

${ }^{64}$ SIDNEY E. MEAD, THE LIVELY EXPERIMENT: THE SHAPING OF CHRISTIANITY IN AMERICA 60 (1963) (quoting Winfred E. Garrison, Characteristics of American Organized Religion, 256 ANNALS AM. ACAD. POL. \& SOC. SCI. 14, 16-17 (1948)).

${ }^{65}$ Gaustad, supra note 33, at 23-24; see also BONOMI, supra note 20 , at 14 ("Only through ... [an established church], so the [colonial] leaders believed, might the colonists ward off the evils of religious strife ...."). For a similar argument by Yale president Timothy Dwight in the post-First Amendment period, see 4 TIMOTHY DWIGHT, Letter V: Vindication of the Establishment of the Public Worship of God by Law, in TRAVELS IN NEW ENGLAND AND NEW YORR 283, 284-85 (Barbara M. Solomon ed., 2d ed. 1969).

${ }^{66}$ For an overview of the disarray that attended Maryland's experiment, see BONOMI, supra note 20, at 21-24.

67 Murrin, supra note 26, at 21.

${ }^{68} \mathrm{MEAD}$, supra note 64, at 59. James Madison later wrote that "the prevailing opinion in Europe, England not excepted, has been that Religion could not be preserved without the support of Government nor Government be supported without an established religion." Letter from James Madison to Reverend Jasper Adams (1832), in CHURCH AND STATE IN AMERICAN HISTORY 77 (John F. Wilson ed., 1965). Consequently, "[i]t remained for North America to bring the great \& interesting subject to a fair, and finally to a decisive test." Id. 
religious freedom; its attention has been on the realm of ideas. But the clash of ideas always occurs in a social context. For example, the founding generation's evolving commitment to disestablishment was surely enhanced by the fact of religious pluralism-a condition that may have effectively removed even the possibility of any particular religion achieving exclusive official recognition on the national level. ${ }^{69}$ Thus, as with any significant political development, it will remain debatable whether the adoption of constitutional guarantees for religious freedom resulted more from intellectual forces or from less rational political and social causes. For present purposes, however, it is enough to observe that even if the social fact of religious pluralism created the possibility of and the impetus for religious freedom, the adoption of that position as a centerpiece of the new constitutional order was not achieved, and likely could not have been achieved, without the articulation of a principled intellectual rationale. And in the late eighteenth century, the religious justification provided that rationale. ${ }^{70}$

${ }^{69}$ See John F. Wilson, Religion, Government, and Power in the New American Nation, in RELIGION AND AMERICAN POLITICS, supra note 26, at 77; see also Bradley, supra note 55 , at 721-27 (discussing the impact of pluralism on the founding generation's commitment to disestablishment). For a criticism of the view that the commitment to religious freedom reflected merely a pragmatic response to a religiously pluralistic society, see David Little, The Reformed Tradition and the First Amendment, in THE FIRST FREEDOM: RELIGION AND THE BILl OF RIGHTS 17 (James E. Wood, Jr. ed., 1990).

${ }^{70}$ Although the religious justification is evident in the Virginia debates and in arguments for religious liberty generally, that justification is not conspicuous in the rather tepid congressional discussions of the Establishment and Free Exercise Clauses. Its absence likely reflects the fact that those clauses were initially viewed primarily as federalism measures; legislators did not regard themselves as resolving issues of religious freedom on the merits, but rather as assigning the resolution of such issues to the states. See Wilson, supra note 69, at 78-83. And of course some states were not yet prepared to adopt a general commitment to religious freedom. See Noonan, supra note 52, at 171 (describing post-First Amendment practices of Massachusetts establishment). But cf. Winthrop S. Hudson, "Liberty, Both Civil and Religious," in THE LIVELY EXPERIMENT CONTINUED 71, 81-84 (Jerald C. Brauer ed., 1987) (arguing that citizens of Massachusetts were committed to religious liberty, and on religious grounds, but did not perceive an inconsistency between religious liberty and moderate establishment practices). The most one can say, therefore, is that the religious justification gave central support to the commitment to religious freedom where that commitment was in fact made-for example, in Virginia. 


\section{THE MODERN TRANSFORMATION}

"[T] he First Amendment did not settle the question of religion and government in America," Jon Butler observes. "Instead, it opened a long dialogue-sometimes a heated argument-that has lasted now for almost two centuries."71 Yet although the dialogue has endured, the terms in which the debate is carried on have been visibly transformed.

\section{A. In Absentia: The Vanishing of the Religious Justification}

A striking feature distinguishing the founding generation's discussions of religious freedom from similar discussions in the twentieth century is that the religious justification, so prominent in the earlier period, has largely vanished from the modern debates. To be sure, vestiges or reminders of that justification still appear from time to time. In Zorach v. Clauson, ${ }^{72}$ Justice Douglas declared that " $[w]$ e are a religious people whose institutions presuppose a Supreme Being." 73 In academic legal literature, scholars still on occasion allude to the religious justification. ${ }^{74}$

These instances are notable, however, both for their rarity and for their relative timidity. Justice Douglas's statement is ambiguous; it can easily be understood as a sociological or historical proposition rather than as a statement of religious faith. In any event, Douglas's rhetoric in Zorach represented an idiosyncratic strand in modern judicial opinions. Justice Douglas has been " $[t]$ he only Justice to assert a religious justification at all explicitly."75 And although scholars sometimes allude to the religious justification in their historical discussions, ${ }^{76}$ they rarely if ever offer the same argument

71 Jon Butler, AWASh in a SEa of Farth: Christianizing the AMERICAN PeOple 258 (1990).

72343 U.S. 306 (1952).

$73 \mathrm{Id}$. at 313.

${ }^{74}$ See, e.g., McConnell, supra note 32, at 1496-99 (discussing the meaning of the religious justification in the founding period); $c f$. Ingber, supra note 5, at 285-87, 292, 332 (presenting an argument similar to the view expressed by Madison in Memorial and Remonstrance, not for the purpose of justifying religious freedom, but rather to define religion and to distinguish religious from non-religious claims).

${ }^{75}$ Smith, supra note 15, at 104; see also Harold J. Berman, Religion and Law: The First Amendment in Historical Perspective, 35 EMORY L.J. 777, 779 (1986) (noting that in contrast to earlier periods, "in the twentieth century the interpretation of [the religion] clauses has been based almost entirely on a political, and not on a religious concept ${ }^{n}$ ).

${ }^{76}$ See George Anastaplo, Church and State: Explorations, 19 LOY. U. CHI. L.J. 61, 191 (1987); McConnell, supra note 32, at 1496-99; Williams \& Williams, supra note 18, 
for contemporary use. Perhaps the closest instance, as I shall argue later, turns out to be quite different in character; it can more accurately be understood as a plea for public agnosticism than as a faithful modern rendering of the religious justification. ${ }^{77}$

In short, one simply does not encounter in contemporary judicial opinions or law review articles anything like Jefferson's positive, unembarrassed declaration that religious liberty is essential because "almighty God hath created the mind free" or because any infringement upon religious freedom is a "departure from the plan of the Holy Author of our religion. ${ }^{\text {78 }}$ The religious justification for religious freedom has lost its status in current constitutional discourse. In view of the significance of that justification in producing the initial commitment to religious liberty, its virtual disappearance from contemporary discourse calls for explanation.

Two kinds of explanations present themselves. First, in the current intellectual climate, the religious justification may simply be implausible-it may rest upon assumptions that no longer seem tenable. The process of secularization may have deprived the religious justification of its power to persuade. Second, the religious justification may still be plausible, but for other reasons it may be regarded as inadmissible in academic and legal debate. This possibility is less straightforward than the implausibility explanation, but the notion that an argument can be relevant and even persuasive yet at the same time inadmissible should hardly seem foreign to lawyers. For example, facts that everyone considers to be relevant are routinely excluded from consideration at trial by the rules of evidence. ${ }^{79}$ Other discourses have similar admissibility restrictions. In certain social contexts, everyone understands there

at 853-58. Even in that context, the religious justification is often filtered out. Howe noted that "[i]t is hard for the present generation of emancipated Americans to conceive the possibility that the framers of the Constitution were willing to incorporate some theological presuppositions in the framework of federal government." HowE, supra note 34 , at 8.

77 See infra part III.B.

${ }^{78}$ Virginia Act for Religious Freedom, VA. CODE ANN. \$ 57-1 (Michie 1986), reprinted in VIRGINIA STATUTE, supra note 19, at Xvii.

79 Evidentiary restrictions are formal and explicit; other constraints are unwritten but no less real. Asked by an appellate court to explain a troublesome precedent, for instance, a lawyer is likely to offer a "legal" account rather than a psychological or political explanation. The lawyer and the judges might be legal realists who believe that a psychological or political explanation is in fact more illuminating, but in the context of appellate argument it is inadmissible to assert that a previous judge made a particular decision because she had an authoritarian personality or was a Carter appointee. 
are some kinds of statements-"My, but you've been putting on weight!" or "This conversation is really tedious, isn't it?"-that simply are not made, even if (or especially if) they are obviously true. It is possible that the religious justification is excluded from current legal and academic debate by analogous admissibility restrictions. ${ }^{80}$ Both possibilities-that the religious justification is implausible and that it is inadmissible-deserve examination.

\section{B. The Secularization Hypothesis: Is the Religious Justification Plausible Today?}

The suggestion that the religious justification is implausible is closely correlated with what might be called the secularization hypothesis. This hypothesis perceives in modern history a process of steady secularization, with a concomitant decline in religious belief. ${ }^{81}$ This diagnosis, if accurate, could provide a fully adequate explanation for the disappearance of the religious justification from constitutional discourse: it would be entirely natural that with the loss of religious belief judges and scholars would cease to rely on arguments that are dependent on such beliefs.

The secularization hypothesis has recently been challenged, however, by sociologists, historians, and public opinion researchers. $^{82}$ In a perceptive essay, Martin Marty argues that from the time of the exploration of the American continent onward, the

${ }^{80}$ See David M. Smolin, The Judeo-Christian Tradition and Self-Censorship in Legal Discourse, 13 U. DAYTON L. REV. 345, 345-47 (1988) (describing as "self-censorship" the common assumption that theistic and Judeo-Christian beliefs cannot properly be invoked in support of legal arguments).

81 One commentator contends that "[s]ecularization has continued apace in the intervening two centuries [since the adoption of the First Amendment], and the struggle for predominance between a fundamentally religious and a fundamentally secular worldview is long since over in western intellectual, political and legal thought." Stephen Pepper, Taking the Free Exercise Clause Seriously, 1986 B.Y.U. L. REv. 299, 306-07; see also Leo Pfeffer, Issues that Divide: The Triumph of Secular Humanism, 19 J. CHURCH \& ST. 203, 211 (1977) (arguing that the now rapid movement towards secularization is certain to continue").

82 See Ronald J. McAllister, Religion in the Public Arena: A Paradox of Secularization, $30 \mathrm{~J}$. CHURCH \& ST. 15, 16 (1988) (noting that evidence fails to support the "traditional view" which holds that "the forces of secularization are unidirectional, disbarring religion and enervating religious values"); see also Everett C. Ladd, Secular and Religious America, in UNSECULAR AMERICA 14, 14 (Richard J. Neuhaus ed., 1986) [hereinafter UNSECULAR AMERICA] ( ${ }^{*} \mathrm{~A}$ quarter century ago there was something approaching consensus . . . that America had entered a period in which religion was in a permanent state of weakness or decline. Today, few scholars feel sure that this is so, and some feel quite the opposite."). 
anticipation of imminent secularization has been perennial, and perennially disappointed. ${ }^{83}$ William Lee Miller adds:

The successive waves of American intelligentsia keep expecting religion to have vanished; or they write as though it has already done so, and then are continually surprised that it has not .... [T]hey say, about religious affirmations, "nobody believes that anymore." One is reminded of the statement that Yogi Berra is said to have made about a well-known restaurant: "Nobody goes there anymore. It's too crowded. ${ }^{84}$

Given these divergent assessments, one may wonder how convincing is the evidence for the secularization hypothesis. Perhaps the strongest argument favoring the theory stems from a negative inference. If religious belief remains strong and pervasive, one would expect to find abundant public manifestations of that belief. Such manifestations were, after all, pervasive in the colonial and founding periods. ${ }^{85}$ In some social domains, however, this evidence is conspicuously absent today. For example, a foreign observer who studied American movies and network television might naturally conclude that religion had wholly lost its significance in American life. ${ }^{86}$

The evidence supporting this negative inference is mixed, however, at best. Although genuine religion may have largely disappeared from movies, television, and the public school classroom, ${ }^{87}$ church attendance is reportedly as high as ever, ${ }^{88}$ and politicians

${ }^{83}$ See Martin E. Marty, The Sacred and Secular in American History, in TRANSFORMING FAITH: THE SACRED AND SECULAR IN MODERN AMERIGAN HISTORY 1 (M.L. Bradbury \& James B. Gilbert eds., 1989) [hereinafter TRANSFORMING FAITH]. Marty cautions against interpretations that divide the sacred from the secular, arguing that we have a "religio-secular, operative-passional, sacro-secular life and society." Id. at 8.

84 Miller, supra note 26, at 36-37.

${ }^{85}$ See supra text accompanying note 31 .

${ }^{86}$ Cf. Frederick M. Gedicks \& Roger Hendrix, Democracy, Autonomy, and Values: Some Thoughts on Religion and Law in Modern America, 60 S. CAL. L. REV. 1579, 1581 (1987) (" $[$ O $]$ ne looks in vain for a television family that attends services, even if only on Christmas or Easter (or Rosh Hashanah or Yom Kippur). Such depictions of religious devotion passed from the cultural scene long ago."); see also ADAMS \& EMMERICH, supra note 14 , at 49 ("In modern advertising media, religion is invariably excluded so as not to offend potential consumers, hence reinforcing the irrelevance of spiritual values to public life.").

${ }^{87}$ Religion's disappearance from the public schools provides equivocal evidence of the status of religious beliefs in the culture, of course, because that disappearance was to a significant extent the product of judicial decree.

${ }^{88} \mathrm{Se} e$ ANDREW M. GREELEY, RELIGIOUS CHANGE IN AMERICA 42-56 (James A. Davis \& John Modell eds., 1989). 
still find it natural and apparently profitable to employ religious symbols and rhetoric. ${ }^{89}$ Nevertheless, even to the extent it is factually well-founded this negative argument is inconclusive because there is another possible interpretation of the evidence, which can be called the privatization hypothesis. This position holds that religious belief is still pervasive, but that believers have come to view their religious faith as a private matter not properly invoked in public discussion. ${ }^{90}$ In this vein, Thomas Luckmann contends that what has changed in modern society is the "location" of religion. ${ }^{91} \mathrm{He}$ acknowledges that "religion is not disappearing from modern society and ... it is anything but shrinking." ${ }^{92}$ Yet the pervading theme in modern religion is "privatization": individuals view religion not as a force that may properly influence public policies, but rather as an aid with individual concerns such as "selfrealization,' personal autonomy, and self-expression. ${ }^{93}$

Either the secularization or the privatization explanation might account for the relative dearth, at least in some social contexts, of public manifestations of religious belief. On the first interpretation, the lack of these manifestations reveals an actual loss of belief; in

${ }^{89}$ See Norman Dorsen, The Religion Clauses and Nonbelievers, 27 WM. \& MARY L. REv. 863, 864-65 (1986) (describing and criticizing the use of religious rhetoric and imagery by Ronald Reagan, Jesse Jackson, and Jimmy Carter); $c f$. Gedicks \&. Hendrix, supra note 86 , at $1596 \mathrm{n.78}$ (noting that "churches and other religious organizations are heavily engaged in movements relating to arms control, abortion restrictions, suppression of pornography, American policy in Central America, disinvestment and anti-apartheid in South Africa, . . . immigration policy, and so-called morals legislation such as anti-prostitution and anti-sodomy laws"). For useful overviews of the influence of religion on American politics, see ROBERT B. FOWLER, RELIGION AND POLTICS IN AMERICA (1985), and A. JAMES REICHLEY, RELIGION IN AMERICAN PUBLIC LIFE 168-339 (1985).

${ }^{90}$ See Frederick M. Gedicks, Some Political Implications of Religious Belief, 4 NoTRE DAME J.L. ETHICS \& PUB. POL'Y 419, 421 (1990) (observing that 'there is in the United States a strong cultural assumption that religion should be private, and politics should be secular").

${ }^{91}$ See Thomas Luckmann, Shrinking Transcendence, Expanding Religion?, 51 Soc. ANALYSIS 127, 132 (1990).

92 Id. at 127.

$93 \mathrm{Id}$. at 138. As a European scholar interested in religion in Western societies generally, Luckmann may be less accurate with respect to the role of religion in the United States. Data suggest that religious belief and commitment are dramatically higher in this country than in most European countries. See generally Theodore Caplow, Contrasting Trends in European and American Religion, 46 SOC. ANALYSIS 101, 102-03 (1985) (offering data which reveal a greater "religious vitality" in the United States than in Europe). Nevertheless, Robert Wuthnow offers a diagnosis of American religion that is similar to Luckmann's more general assessment. See ROBERT WUTHNOW, THE RESTRUCTURING OF AMERICAN RELIGION 300 (1988). 
the other view, the absence of public manifestations of belief only shows that believers are keeping their faith to themselves. As between these explanations, the privatization explanation is the more plausible, at least with respect to the general population. What proves decisive on this question is the abundance of survey and sociological evidence indicating the continuing strength of religious belief:

Upwards of 90 percent of the American population affirms some belief in the existence of God.... [N]ine persons in ten believe Jesus Christ actually lived, seven in ten believe he was truly God, and six in ten think one must believe in the divinity of Christ to be a Christian. The results of studies documenting consistently high levels of belief in life after death, heaven, and Christ's presence in heaven also point to the survival of a strong element of religious dualism in American culture. ${ }^{94}$

Localized studies and data reinforce this survey evidence. In an intensive study of Muncie, Indiana-the "Middletown" of repeated sociological studies beginning early in this century-a team of sociologists concluded that the "secularization" thesis was flatly incorrect. The evidence showed, if anything, a trend toward "sacralization." D5 Data from Brooklyn, New York, support a similar conclusion. ${ }^{96}$

The analysis thus far has considered the persistence of religious belief in the public at large and suggested that the privatization thesis is more consistent with the available data than the secularization thesis. It is possible, however, that a different assessment is warranted for the more educated part of the population, sometimes referred to as the "knowledge class," to which judges, lawyers, and legal academicians belong. Some scholars have suggested that academicians form a distinct "intellectual subsociety"97 whose

94 WUTHNOW, supra note 93, at 300; see also GREELEY, supra note 88 , at $13-20$ (arguing that data show stability in Americans' central doctrinal beliefs); Caplow, supra note 93, at 103 ("America is distinctly more pious [today] than two generations ago.").

95 See Theodore Caplow et al., All faithful People: Change and CONTINUITY IN MIDDLETOWN'S RELIGION 297 (1983). For an argument challenging the Middletown study, see Norval D. Glenn, The Trend in "No Religion" Respondents to U.S. National Surveys, Late 1950s to Early 1980s, 51 PUB. OPINION Q. 293 (1987). On the basis of an increase in the percentage of persons who reported they had no religion-a percentage that at all times remained in the single digits-Glenn infers a broad secularizing tendency in this country that continued from the 1950 s until about 1980, but apparently reversed itself in the 1980s. See id. at 311-12.

${ }^{96} \mathrm{See}$ WUTHNOW, supra note 93 , at 4.

${ }^{97}$ See Milton M. Gordon, The Intellectual Subsociety, in THE PrOFEssORs: WORK 
values and beliefs may differ significantly from those of citizens generally. Thus, the disappearance of the religious justification for religious freedom and of religious arguments from legal debate might be explained as the consequence of a loss of religious faith not in the general population, but rather in the "knowledge class," and in particular among judges, lawyers, and legal academicians. ${ }^{98}$

In contrast to the general secularization hypothesis, the possibility of a localized, class-based loss of religious belief is harder to evaluate. The argument based on a negative inference from the lack of public religiosity seems stronger in the academic context. Henry May claims that "since the First World War or a little earlier, religion has ceased to have a place in the established culture of the intellectuals." 99 The absence of overt manifestations of religiosity within intellectual culture creates a strong impression of secularization. Although he goes on to challenge the accuracy of the depiction, James Boyd White describes the common view as follows:

There is a peculiar division between academic and religious thought in our culture. In the academic world we tend to speak as though all participants in our conversations were purely rational actors engaged in rational debate; perhaps some people out there in the world are sufficiently benighted that they turn to religious beliefs or other superstitions, but that is not true of us or, if it is true, we hide it, and it ought not be true of them. Ours is a secular academy and, we think, a secular state. ${ }^{100}$

Once again, however, the negative inference is fragile. In academic culture, as in the culture at large, the absence of explicit and public religiosity might be the result of a "privatization," not of a "secularization" entailing the actual loss of religious faith. ${ }^{101}$

AND LIFE STYLES AMONG ACADEMICLANS 219, $219-21$ (Charles H. Anderson \& John D. Murray eds., 1971). For a recent, much discussed argument depicting legal theory as a tool of the "knowledge class" in opposition to the general public, see ROBERT BORK, THE TEMPTING OF AMERICA (1989).

${ }^{98}$ For a discussion of the lack of religious faith among intellectuals, see Smolin, supra note 80 , at $388-94$.

99 HENRY F. MAY, IDEAS, FATTHS, AND FEELINGS: ESSAYS ON AMERICAN INTELLECTUAL AND RELIGIOUS HISTORY 1952-1982, at 158 (1983).

100 James B. White, Response to Roger Cramton's Article, 37 J. LEGAL EDUC. 533, 533 (1987). Similarly, speaking from his broad experience in the legal academy, Kent Greenawalt reports that "[a] good many professors and other intellectuals display a hostility or skeptical indifference to religion that amounts to a thinly disguised contempt for belief in any reality beyond that discoverable by scientific inquiry and ordinary human experience." KENT GREENAWALT, RELIGIOUS CONVICTIONS AND POLITICAL CHOICE 6 (1988).

101 This possibility is implicitly recognized even in the observations of James Boyd 
The data on this point are inconclusive. Survey evidence from the 1980 s, however, suggests that most of the more educated citizens hold religious beliefs. ${ }^{102}$ Among college graduates in this country, only 3\% say they do not believe in God, while $77 \%$ report that their relationship with God is either "extremely close" or "somewhat close." ${ }^{103}$ The percentage of college graduates who believe in life after death $(76 \%)$ is the same as that for the general population, ${ }^{104}$ and the percentage of college graduates who attend church nearly every week ( $30 \%)$ is slightly higher than the national average. ${ }^{105}$ College graduates express greater confidence in organized religion than persons who have graduated from high school only. ${ }^{106}$ And although college graduates are far less likely to be biblical literalists, $80 \%$ believe the Bible to be the "actual word of God" or the "inspired word of God." 107

Even though the category of college graduates may not be coextensive with "the knowledge class" or the "intellectual subsociety," college graduates comprise and, presumably, are influenced by that subculture. Hence, the persistence of high levels of religious belief among college graduates at least casts doubt on the proposition that intellectuals and academicians have generally lost their religious faith.

In addition, survey evidence reveals that $63 \%$ of educators regard themselves as "religious"; the figure for individuals in vocations associated with law and justice is $53 \% .^{108}$ More than

White and Kent Greenawalt quoted above. White recognizes that "if it is true [that academics hold religious beliefs], we hide it." White, supra note 100, at 533 (emphasis added). Greenawalt, although discerning academic hostility to religion, asserts that this hostility is "disguised." GREENAWALT, supra note 100, at 6 . But if the hostility is "disguised," how does Greenawalt know that it exists? One likely possibility is that Greenawalt infers hostility to religion from the conspicuous failure of academics to acknowledge or invoke it. But it is also possible that academics do not invoke religious beliefs in public discussions because they regard such beliefs as personal or private in nature.

102 See UNSECULAR AMERICA, supra note 82, app. at 142, tbl. 20; $f$. Ladd, supra note 82 , at $22-23$ (noting that survey evidence reveals no significant differences in religiosity on the basis of education or age differences).

${ }_{103}$ See UNSECULAR AMERICA, supra note 82, app. at 142, tbl. 20.

${ }^{104}$ See id. at 141. In addition, compared to the general population, college graduates appear to have more definite and positive ideas about what the next life will be like. See id. at 136.

105 See id. at 139.

${ }^{106}$ See id. at 138. Confidence in organized religion is higher still among persons who have not graduated from high school. See id.

107 See id. at 143.

108 See id. at 146. 
three-quarters of those in both groups attend church at least occasionally, and over one third attend frequently. ${ }^{109}$ About the same percentages participate occasionally, or frequently, in prayer. ${ }^{110}$ Thus, although religion may have largely disappeared from intellectual culture, its absence does not necessarily reflect any comparable decline of faith among the individuals who compose that culture. It appears, rather, that many participants in intellectual or academic culture continue to hold religious beliefs but do not view those beliefs as matters to be properly invoked in public discussion. ${ }^{111}$

A recent study of religiosity among psychotherapists provides indirect support for this interpretation. ${ }^{112}$ Like lawyers and legal academics, psychotherapists undergo years of education beyond the undergraduate level. Unlike lawyers, psychotherapists receive training that might, in a fairly direct way, challenge or undermine religious faith. Most casebooks, legal treatises, and legal articles do not directly speak to religious belief; by contrast, seminal figures in psychology, particularly Freud, have explained religious belief as a form of wish-fulfillment and illusion. ${ }^{113}$ Accordingly, psychotherapists might be expected to be especially secularized, and they have often been perceived as such. ${ }^{114}$ The recent study confirms that by most indicators psychotherapists are indeed less religious than the general population. ${ }^{115}$ Nonetheless, $77 \%$ of the psychotherapists surveyed agreed with the statement: "I try hard to live my life according to my religious beliefs." 116 Moreover, $46 \%$ agreed with the statement: "My whole approach to life is based on my religion." 117 In addition, $41 \%$ indicated that they attend religious

109 See id. at 139 .

110 See id. at 147.

${ }^{111}$ Cf. Smolin, supra note 80, at 415 (arguing that "[t]oo many [Christian scholars] have been content to relegate their faiths to their private lives, while moving quietly and safely amongst their colleagues").

${ }^{112}$ See Allen E. Bergin \& Jay P. Jensen, Religiosity of Psychotherapists: A National Survey, 27 PsYchOTHERAPY 3 (1990).

${ }^{113}$ See, e.g., Sigmund FreUd, THE Future of AN Illusion 25-58 (W.D. RobsonScott trans., 1928). For a discussion of Freud's "psychoanalytic atheism," see HaNs KÜNG, DOES GOD EXIST? 262-323 (Edward Quinn trans., Vintage Books 1981) (1978).

114 See Bergin \& Jensen, supra note 112, at 3.

115 For example, $20 \%$ of the psychotherapists surveyed were atheists, agnostics, or without any religious preference. The same was true of only $9 \%$ of the public at large. See id. at 4-5.

${ }_{116}$ See id. at 5 . In comparison, $84 \%$ of the general population agreed with the similar statement: "I try hard to put my religious beliefs into practice in my relations with all people." See id.

${ }^{117}$ See id. In contrast, $72 \%$ of the general public agreed with the similar 
services regularly. ${ }^{118}$ Thus, the perception of a lack of religious faith among psychotherapists apparently reflects a privatization of religious belief, not outright secularization. ${ }^{119}$

Thomas Shaffer provides impressionistic support for a similar conclusion with specific reference to the legal profession. Shaffer observes that he and other legal educators "have taught scores of law students who came to, lived through, and left law school with firm, active religious commitments. ${ }^{120}$ But these students quickly learned that their religious convictions were not to be appealed to in legal discussions:

A remarkable thing happens to these students when they start talking about public law; they come to regard themselves as culturally disembodied. There is something about the way lawyers are trained, and I suspect it is the constitutional law teachers who do this, that makes even the most pious believer look at her church as if she were not in it anymore. She learns, for professional purposes, to stand on the courthouse steps and look at the community that formed her as if being a lawyer had removed her to a new community, even though that has not happened, even though she is still very much in the community she came fromteaches Sunday school, sings in the choir, tithes, and serves on the board. ${ }^{121}$

Other legal scholars offer comparable observations. Discussing the problem of teaching values in the legal curriculum, Roger Cramton noted that for himself and other legal educators religious beliefs are often an important source of values. ${ }^{122}$ This religious foundation might easily go unnoticed, however, because deeply held moral beliefs in general, and religious beliefs in particular, are not likely to appear in any law school discussion. The presentation of such personal beliefs in that context, Cramton observed, conflicts with "the tacit agreement of academic culture, at least in recent times, that the classroom is to be resolutely secular and 'value-

statement: "My religious faith is the most important influence in my life." See id.

${ }^{118}$ See id. at 4.

119 The researchers concluded that " $[t]$ here . . . appears to be a significant degree of unrecognized religiousness among therapists. Some of this religious interest is expressed in conventional ways, such as in affiliation and attendance, but a sizeable portion appears to be less conventional and more personal in form." Id. at 6.

120 Thomas L. Shaffer, On Checking the Artifacts of Canaan: A Comment on Levinson's "Confrontation," 39 DEPAUL L. REv. 1133, 1140 (1990).

121 Id.

122 See Roger C. Cramton, Beyond the Ordinary Religion, 37 J. LECAL EDUC. 509, 515 (1987). 
free." 123 In response, James Elkins agreed that "[m]any of us are acutely aware of the need for a spiritual sensibility in our professing and in our profession." ${ }^{124}$ But the difficulty is that "[r]eligion and law make for odd talk. . . . A conversation that admits the reality of religion and spiritual values violates our perception of public and private, social and personal. ${ }^{n 125}$ These observations support the general survey evidence: both suggest that the "privatization" thesis is a more accurate description of general and academic culture than the more unqualified "secularization" thesis.

To be sure, the conclusion that the scarcity of public manifestations of religious belief reflects a privatization of faith, rather than a loss of faith, rests partially upon survey evidence limited in what it can prove. ${ }^{126}$ Survey evidence measures religiosity at a relatively superficial level. Data reporting the prevalence of belief in God, in an afterlife, and in the Bible reflect the propositions to which subjects give intellectual assent, but such data do not show whether that assent is based on serious reflection or merely on habit or tradition; nor does the survey evidence measure the strength or depth of the subjects' religious convictions. ${ }^{127}$

Although the survey evidence measures religiosity primarily on the level of intellectual assent, it is that level which is most pertinent to the question at issue. The evidence suggests that large majorities of Americans, including more educated Americans, at least give intellectual assent to traditional religious beliefs. Whatever the strength of their religious commitments, Americans continue to find these beliefs plausible. Indeed, it is quite likely that many, or even most, Americans would assent to both the priority claim ${ }^{128}$ and the voluntariness claim. ${ }^{129}$ Consequently, the disappearance of the religious justification from modern discourse cannot be

${ }^{123} \mathrm{Id}$. at 516.

124 James R. Elkins, Reflections on the Religion Called Legal Education, 37 J. LEGAL EDuc. 522, 525 (1987).

125 Id. at 527.

${ }^{126}$ For a discussion of some of the complexities in religious faith that survey evidence could not hope to capture, see infra part IV.G.

${ }^{127}$ Even so, data showing relatively high and stable levels of church attendance and prayer would seem to reflect more than mere intellectual assent. See GREELEY, supra note 88 , at $42-66$.

${ }^{128}$ See J. Morris Clark, Guidelines for the Free Exercise Clause, 83 HARV. L. REV. 327, 336 (1969) (asserting that "most Americans also feel sympathy for the proposition that the theist's highest duty is to serve God").

${ }^{129}$ See Williams \& Williams, supra note 18 , at 770 ("Volitionalism pervades American thinking about law, politics, religion, and morality." ). 
adequately explained by the hypothesis that its religious premises are viewed as implausible. Something more complex seems to be going on. It is likely that the religious justification, along with religious beliefs generally, is not regarded as implausible but rather as inadmissible in public debate.

\section{G. The Controversial Character of Religious Belief}

The foregoing discussion suggests that there is nothing in the propositional content of common religious beliefs that renders them a priori irrelevant to public concerns. If beliefs in God, the Bible, and basic Judeo-Christian precepts were pertinent to public issues like religious freedom two centuries ago, beliefs expressed in similar terms would presumably be pertinent to those issues today. Nonetheless, many believers, particularly in academic culture, seem to regard their religious beliefs as inadmissible in public debate. The question is: why?

In the next section $I$ argue that the inadmissibility of religious beliefs, and of the religious justification for religious freedom in particular, is in part a consequence of what we have come to understand religious freedom to mean. Before pursuing that argument, however, it may be useful to consider an alternative explanation closely associated with the view that religious beliefs are no longer plausible. A modification of the secularization hypothesis, this explanation suggests that even if most Americans, including more educated Americans, continue to hold religious beliefs, the crucial fact is that significant numbers of Americans do not hold such beliefs. In the founding period, James Turner has argued, disbelief in God was not an intellectual option for Americans: although charges of "atheist" and "infidel" were bandied about, there were for practical purposes no true atheists in this country. ${ }^{130}$ Today, by contrast, persons who reject all conventional religious belief constitute a minority, but their presence is undeniable. In addition, religious believers in this country may differ more substantially in the content of their beliefs than they did two centuries ago. ${ }^{131}$ In short, the critical change is that religious

${ }^{130}$ See supra note 29.

131 See MaRy F. BedNarowski, American Religion: A Cultural Perspective 2-3 (1984) (describing the wide variety of religions in the United States today). But see R. LAURENCE MOORE, RELIGIOUS OUTSIDERS AND THE MAKING OF AMERICANS 205 (1986) (observing that "although one can count hundreds of religious groups in the United States, the vast majority of religious Americans have gravitated toward a small 
belief, however widespread, is now openly controversial, and therefore genuinely optional. And precisely because it is optional, religious belief cannot serve as a solid ground or starting place for legal or academic discussion. ${ }^{132}$ After all, "the orator who builds his discourse on premises not accepted by the audience commits a classical fallacy in argumentation-a petitio principii." 133

Initially, this explanation for the disappearance of the religious justification from academic and judicial discourse seems eminently plausible. Nonetheless, the contention that the religious justification is inadmissible because its religious premises are controversial does not provide a complete and satisfactory explanation for that justification's disappearance from contemporary discourse. The difficulty is that the explanation's premise-that controversial beliefs cannot provide suitable grounds for legal or academic argumenthas little force outside the specific domain of religious belief. ${ }^{134}$ Legal scholars normally do not hesitate to rely upon theories or beliefs just because those theories or beliefs are rejected by many of their colleagues. Quite to the contrary, scholarly literature teems with analyses and arguments based upon the views or theories of Aristotle, Bentham, Derrida, Dewey, Gadamer, Habermas, Hegel, Kant, Marx, Merleau-Ponty, Mill, Pierce, Rawls, Rorty, and Wittgenstein, to name a few. None of these thinkers or their theories even approach general acceptance. Indeed, it seems unlikely that more than a minority of legal scholars-in some cases

number of 'mainline' denominations"). At the end of the nineteenth century the ten largest denominations accounted for $75 \%$ of the American population; today they represent $90 \%$. See id. at 206.

132 One writer observes:

By the midpoint of the 19th century, it had become clear that no single religious denomination would ever dominate the American cultural scene .... As a consequence, there was no single denominational language that was adequate to the task of communication among such a theologically diverse population. Of necessity, Americans began to move toward a less sectarian language in public life. It was only by using a more secular language that one could carry on public business and dialogue without importing into the discussion ... divisive theological differences ....

Gedicks, supra note 28, at 120; see also Kenneth A. Strike, Are Secular Ethical Languages Religiously Neutral?, 6 J.L. \& POL. 469, 470 (1990) ("A people with diverse religious commitments, or none, need a common ethical language that is both secular and religiously neutral.”).

133 ChaIM Perelman, The New RHetoric and the Humanimies 14-15 (1979).

${ }^{134}$ Cf. Stephen L. Carter, The Inaugural Development Fund Lectures: Scientific Liberalism, Scientistic Law, 69 OR. L. REv. 471, 500 (1990) ("[W] hat about the point that we are as morally diverse as we are religiously diverse, and yet we allow all sorts of moral views to be expressed and even imposed? How is religion different?"). 
hardly more than a handful-subscribes to any of the theories. Nonetheless, it is common and apparently respectable for legal scholars to invoke the authority of these thinkers or to use their theories as grounds for legal debate.

Reliance upon controversial premises in public argument is not only common, but inevitable. In a diverse, pluralistic culture there are few if any beliefs that approach universal acceptance, and generally shared beliefs are likely to prove inadequate to resolve many specific issues that need to be addressed. With respect to numerous moral and political issues, for example, public argument inevitably rests upon competing premises that are often controversial and incommensurable. ${ }^{135}$ After an extensive analysis, Kent Greenawalt concludes that "any hope that all political issues can be resolved solely on the basis of commonly shared premises about values and commonly shared approaches to factual knowledge must be abandoned."136

Given this situation, it is unsatisfactory to explain the disappearance of the religious justification from legal discourse merely by noting that the justification's religious assumptions are controversial. Something more complicated appears to be at work. ${ }^{137}$ It seems that even citizens and scholars who accept and act upon religious beliefs in their personal lives, and who are also quite comfortable invoking controversial nonreligious premises or theories in public discussions, nonetheless assume that religious beliefs are inadmissible in public discourse about matters such as constitutional law. In the following section I propose an explanation for that perceived inadmissibility.

\section{The Self-Gancellation of the Religious Justification}

The answer to the question of why the religious justification should be regarded as inadmissible in legal and academic debate is surely multifaceted. ${ }^{138}$ In the discussion to follow I do not pre-

135 See AlASDAIR MACINTYRE, AFTER VIRTUe 6-8 (2d ed. 1984).

136 GREENAWALT, supra note 100 , at 216.

${ }^{137}$ Cf. Kent Greenawalt, Religious Convictions and Political Choice: Some Further Thoughts, 39 DEPAUL L. REv. 1019, 1035 (1990) ("Considering the extent to which Americans regard themselves as religious, the marginalization of religion in our culture's intellectual life . . . is somewhat surprising . ...").

${ }^{138}$ See Stephen Hart, Privatization in American Religion and Society, 47 Soc. ANALYSIS 319, 321-25 (1987) (discussing various sources of religious privatization). For discussions linking the exclusion of religion from public discourse to broader intellectual and political currents related to the Enlightenment, the rise of liberalism, 
tend to provide a comprehensive account, but instead emphasize one important factor that has contributed to this cultural phenomenon. I will suggest that the discourse restriction precluding use of the religious justification can be understood as a natural consequence of what may be called the prohibitory interpretation of religious freedom. In this interpretation, constitutional religious freedom operates as a prohibition forbidding governmental reliance upon religious doctrines or beliefs in the formulation of public policy. Ronald Dworkin expresses this view when he asserts that "the Constitution does not allow states to justify policy on grounds of religious doctrine." 139 As the prohibitory interpretation has gained acceptance, ${ }^{140}$ it is not surprising that our legal and academic discourse cease to advance the religious justification as a rationale for religious freedom. The religious justification, after all, is precisely the kind of religious belief or rationale that the prohibitory interpretation excludes as a basis of public policy. ${ }^{141}$

and the development of science, see Carter, supra note 134, and Gedicks, supra note 28 , at $116-26$.

${ }^{139}$ Ronald Dworkin, The Right to Death, N.Y. Rev. Books, Jan. 31, 1991, at 14, 17.

140 See, e.g., Steven G. Gey, Why Is Religion Special?: Reconsidering the Accommodation of Religion Under the Religion Clauses of the First Amendment, 52 U. PTTT. L. REv. 75,179 (1990) (" $T$ T] he establishment clause removed from political discourse the final resort to the Almighty that had previously characterized determinations of political truth .... Religious values ... cannot be written into law ....”); Ira C. Lupu, Keeping the Faith: Religion, Equality and Speech in the U.S. Constitution, 18 CoNN. L. REV. 739, 746 n.30 (1986) (arguing that the religion clauses require elimination of "all references to God in public life"); Frederick Schauer, May Officials Think Religiously?, 27 WM. \& MARY L. REV. 1075 (1986) (arguing that the roles of public officials may preclude their use of religious reasoning); Mark V. Tushnet, The Constitution of Religion, 18 CONN. L. REV. 701, 733 (1986) (observing that "the liberal political tradition excludes religion from public life"); $c$. LEO PFEFFER, CREEDS IN COMPETITION 43 (1958) (equating "the separation of church and state" with "the secular state"); JOHN M. SWOMLEY, RELIGIOUS LIBERTY AND THE SECULAR STATE 17 (1987) (contending that the "constitutional doctrine of separation of church and state" means that "[t]he Constitution ... provides for a wholly secular government"); Gail Merel, The Protection of Individual Choice: A Consistent Understanding of Religion Under the First Amendment, 45 U. CHI. L. REV. 805, 813 (1978) (asserting that the American constitutional democracy is "a political order that is ultimately premised upon a wholly secular politics"); James E. Wood, Jr., "No Religious Test Shall Ever Be Required": Reflections on the Bicentennial of the U.S. Constitution, 29 J. CHURCH \& ST. 199, 207-08 (1987) (arguing that the Constitution makes the United States "a secular state").

141 Michael Smith observes:

The Supreme Court has laid down the rule that government may not act toward religion for religious purposes. Presumably, "religious purposes" include contentions about God's will and value judgments that relate to religion alone. If so, not to hinder religion because that is what God wills is to act for religious reasons. This justification violates the very rule against 
If government is forbidden to act upon a particular rationale, for lawyers or legal academicians to assert and debate the rationale would at best be futile, while at worst it might taint or invalidate policies that correspond to prescriptions derived from the forbidden rationale.

\section{A. Emergence of the Prohibitory Interpretation}

The prohibitory interpretation of religious freedom is neither inevitable nor uncontroversial. ${ }^{142}$ Michael Sandel observes that "the reigning interpretation of religious liberty is not characteristic of the American constitutional tradition as such, but a recent development that departs from earlier understandings." 143 In fact, the prohibitory interpretation stands in tension not only with the constitutional history recounted above, which reflects the fact that a religious rationale was employed in the achievement of religious freedom, but also with the prevailing early understanding of religious freedom, which emphasized the institutional separation of church and state, not the insulation of government from religious beliefs and values. ${ }^{144}$ In addition, the prohibitory interpretation conflicts with much of our subsequent political history in which religious beliefs have actively influenced public policies of all kinds, ranging from abolition to prohibition to civil rights legislation. ${ }^{145}$

Nonetheless, the initial commitment to a modest, institutional interpretation of religious freedom contained the germ of its own expansion. That potential was discernible in the thinking of James

religious purposes to which it ostensibly gives rise.

Smith, supra note 15, at 117 .

${ }^{142}$ For contemporary scholarship that rejects the prohibitory interpretation, see MICHAEL J. PERRY, LOVE AND POWER: THE ROLE OF RELIGION AND MORALITY IN AMERIGAN POLITICS (forthcoming 1991); Stephen L. Carter, The Religiously Devout Judge, 64 NOTRE DAME L. REV. 932 (1989); Steven D. Smith, Separation and the "Secular": Reconstructing the Disestablishment Decision, 67 TEX. L. REV. 955 (1989).

143 Michael J. Sandel, Freedom of Conscience or Freedom of Choice?, in ARTICLES OF FATTH, supra note 26 , at 77 .

144 I have argued at greater length for this interpretation in Smith, supra note 142. See also ADAMS \& EMMERICH, supra note 14, at 51 (asserting that "the Founders conceived of separation in institutional rather than cultural terms"); WINTHROP S. HUDSON, RELIGION IN AMERICA 102 (4th ed. 1987) (arguing that "when the First Amendment was adopted no one thought that 'separation of church and state' ... implied any separation of religion and politics").

${ }^{145}$ See Edward M. Gaffney, Jr., On Not Rendering to Caesar: The Unconstitutionality of Tax Regulation of Activities of Religious Organizations Relating to Politics, 40 DEPAUL L. REv. 1, 9-16 (1990); Michael E. Smith, Religious Activism: The Historical Record, 27 WM. \& MARY L. REV. 1087 (1986). 
Madison, an early proponent of religious freedom. As noted, Madison forcefully invoked the religious justification during the struggle for religious freedom in Virginia. ${ }^{146}$ In 1789, Madison again expressed what seems a modest conception of the scope of religious freedom when as a member of Congress he proposed what became the religion clauses of the First Amendment. He explained in Congress that the amendment meant only "that Congress should not establish a religion, and enforce the legal observance of it by law, nor compel men to worship God in any manner contrary to their conscience."147 Madison was also a member of the committee that recommended the institution of a congressional chaplain, and he apparently voiced no objection either to the chaplaincy plan or to the resolution calling for a national day of "public thanksgiving and prayer, to be observed by acknowledging ... the many signal favors of Almighty God ...."148 However, later in life, especially after retiring from the presidency, Madison seems to have moved toward a more expansive position regarding the meaning of separation; he condemned both the chaplain system and religious proclamations such as the thanksgiving resolution. ${ }^{149}$

Madison's thinking hardly charted an inevitable path. His later opinions cannot plausibly be viewed as the mere working out of necessary or logical entailments of his earlier commitment to the separation of religious and governmental institutions. On the contrary, it is perfectly coherent to hold that the religion clauses require a formal institutional separation of church and state-or to maintain, in Jefferson's famous phrase, that the First Amendment erects a "wall of separation between church and State"150 -without also calling for government to be sealed off from religious beliefs or prohibited from supporting religious values and symbols. ${ }^{151}$ If, however, the evolution in Madison's opinions is not logically

${ }^{146}$ See supra notes 46-47 and accompanying text.

1471 ANNALS OF CONG. 730 (Joseph Gales ed., 1789) (statement of James Madison), quoted in ROBERT L. CORD, SEPARATION OF CHURCH AND STATE: HISTORICAL FACT AND CURRENT FICTION 10 (1982).

${ }^{148}$ CORD, supra note 147 , at $23-29$.

${ }^{149} I d$. at 29-36.

150 The famous metaphor occurred in a letter written by Jefferson to the Danbury Connecticut Baptist Association in 1802. The letter is reprinted in THE COMPLETE JEFFERSON, supra note 11, at 518-19.

${ }^{151}$ I have elsewhere argued that when the problem is considered in light of our political traditions and our constitutional commitments to other values such as the freedoms of speech and belief, the early "institutional separation" position is more coherent than its modern successors. See Smith, supra note 142, at 985-1015. 
inexorable, that evolution does represent a natural dialectical or conceptual progression-and one which has been broadly repeated in modern religion clause jurisprudence.

Thus, one can easily understand how a citizen-or a scholar or judge-might come to regard the prohibitory interpretation of religious freedom as axiomatic. In the first place, if government relies upon religious beliefs in formulating public policies, the resulting policies require conformity to what some citizens may regard as religious programs or agendas. ${ }^{152}$ An obvious example is the case of abortion. Suppose a state legislature places restrictions on the availability of abortion because legislators and citizens believe on religious grounds that abortion is tantamount to murder. The restrictions will likely be viewed by opponents as requiring adherence to a religious code of conduct. Of course, the restrictions do not force anyone to believe a religious doctrine, or to affiliate with or worship according to any religion. But the state's policy does compel nonbelievers to conform to a standard of conduct inspired in large measure by religious belief. Such compulsion can be viewed as imposing, at least in one important matter, a kind of compelled religion, and thus as violating the commitment to religious freedom. ${ }^{153}$

In addition, governmental policies are presumably adopted for reasons that government accepts as credible. Hence, in relying upon a religious belief or value as a reason for adopting a particular policy, government at least tacitly approves or endorses that belief or value, and thereby tacitly disapproves contrary religious or nonreligious views that would not support the governing policy. And one can readily argue that a government which embraces or

152 See Neal R. Feigenson, Political Standing and Governmental Endorsement of Religion: An Alternative to Current Establishment Clause Doctrine, 40 DEPAUL L. REV. 53, 69 (1990) (arguing that "government promotes religion . . . by offering religious justifications for policy").

${ }^{153}$ In Harris v. McRae, 448 U.S. 297 (1980), the Court upheld the Hyde Amendment, which forbids the use of federal Medicaid funds to reimburse abortion costs, against this type of Establishment Clause challenge. The Court ruled that this measure had not been adopted to further a religious objective but instead merely "happen[ed] to coincide" with a religious doctrine: "The Hyde Amendment . . . is as much a reflection of 'traditionalist' values toward abortion, as it is an embodiment of the views of any particular religion." Id. at 319. The Court's discussion implies that if the law had been adopted on religious grounds, it would have violated the Establishment Clause. Determining whether a law is actually grounded in "religious" precepts as opposed to "secular" concerns that "happen to coincide" with religious precepts presents the courts with a virtually impossible and perhaps conceptually incoherent task. See Smith, supra note 142, at 999-1007. 
endorses particular and controversial religious beliefs is not providing full religious freedom for its citizens. It may even seem that citizens whose beliefs are implicitly disapproved are being treated as second-class citizens. ${ }^{154}$ Full religious freedom, one may argue, requires that government be both actually and symbolically neutral in matters of religion; ${ }^{155}$ governmental reliance upon a religious justification is inconsistent with this policy of neutrality. 156

It is not surprising, therefore, that a prohibitory interpretation of constitutional religious freedom has seemed compelling to a number of scholars. ${ }^{157}$ The appeal of that interpretation is not, however, limited to scholars. John F. Kennedy, explaining his understanding of what religious freedom and church-state separation mean in this country, seems to have embraced a version of the

154 This is the current view of the Supreme Court. See infra parts IV.F, V.A.

155 For a defense of this view, see William P. Marshall, "We Know It When We See It": The Supreme Court and Establishment, 59 S. CAL. L. REV. 495 (1986). For my extended criticism of the position, see Steven D. Smith, Symbols, Perceptions, and Doctrinal Illusions: Establishment Neutrality and the "No Endorsement" Test, 86 MICH. L. REV. 266 (1987).

156 The concern for symbolic neutrality is evident in Kent Greenawalt's position, which contains, if not internal contradictions, at least internal tensions. He has criticized at length the argument that religious grounds may never properly influence political decisions. See GREenAwALT, supra note 100 , at 6 . Nonetheless, he believes that government officials should not invoke religious values or premises in explaining or justifying their decisions because citizens should not be led to believe that a political decision was made on religious grounds (even, apparently, if it actually was). See Greenawalt, supra note 137, at 1034-36.

${ }^{157}$ See supra notes $139-40$ and accompanying text; see also DAVID LYONS, ETHICS AND THE RULE OF LAW 189-91 (1984) (suggesting that law should not be shaped by moral judgments); Lawrence B. Solum, Faith and Justice, 39 DEPAUL L. REv. 1083, 1089-97 (1990) (arguing that government should use public as opposed to religious reasons to support its decisions). For descriptions and critical analyses of versions of this "prohibitory" position as articulated by John Rawls, Bruce Ackerman, and Thomas Nagel, among others, see GREenAWALT, supra note 100, at 30-84; PERRY, supra note 142.

Although the present discussion is primarily concerned with legal culture, the prohibitory interpretation's effects on scholars may not be confined to the law schools. Martin Marty observes:

The First Amendment to the Constitution, because it drew what James Madison called a line of distinction between civil and religious authorities, or separated church and state, put a new burden on the public, statesupported historians. They felt they had to expunge most positive references to religion in order to be fair, to give equal time to religion by giving no space to it at all.

Marty, supra note 83 , at 7. 
prohibitory interpretation. As a presidential candidate addressing a group of Protestant ministers, Kennedy asserted:

"[Because] the separation of church and state is absolute [it would be improper for any] religious body [to] seek to impose its will directly or indirectly upon the general populace or the public acts of its officials.... Whatever issue may come before me as President-on birth control, divorce, censorship, gambling or any other subject-I will make my decision ... . in accordance with what my conscience tells me to be the national interest, and without regard to outside religious pressures or dictates. And no power or threat of punishment could cause me to decide otherwise. ${ }^{158}$

Supreme Court Justices have expressed a similar view regarding their own judicial responsibilities. After three decades on the Court, Justice Brennan reported that although he was a Roman Catholic "as a private citizen," his religious beliefs had never influenced his position on legal cases because he had, at the time of his confirmation, "settled in my mind that I had an obligation under the Constitution which could not be influenced by any of my religious principles. ${ }^{\text {159 }}$ Justice Scalia has evinced a similar understanding of his judicial responsibility. ${ }^{160}$

The Supreme Court as a body has not clearly indicated its acceptance of the prohibitory interpretation, but that interpretation is implicit in the Court's pronouncements. The Court has repeatedly declared that religious freedom means governmental neutrality in matters of religion. ${ }^{161}$ And the Court has on numerous occasions interpreted this policy of neutrality to prohibit government from acting except for secular purposes and in ways that have primarily secular effects. ${ }^{162}$

${ }^{158}$ Sanford Levinson, The Confrontation of Religious Faith and Civil Religion: Catholics Becoming Justices, 39 DEPAUL L. REv. 1047, 1055 (1990) (emphasis added) (quoting John F. Kennedy). Kennedy's position arguably begs the question of whether religious beliefs may properly influence public policy. By categorizing the impermissible religious influence as a kind of outside pressure, Kennedy may have left open the possibility that his own sincerely held religious values and beliefs could properly influence the determination of what "my conscience tells me to be the national interest."

${ }^{159} \mathrm{Id}$. at 1063 (quoting Justice Brennan). Brennan seems to have been faithful to his constitutional principles. See Brennan Wasn't as Eisenhower Expected, N.Y. TIMES, Aug. 12, 1990, $\$ 4$, at 20 ( ${ }^{\text {As }}$ the Catholic voice on the court, his voting record rarely showed any hint of Catholic morality entering into his decisions.").

${ }^{160}$ See Levinson, supra note 158, at 1063-64.

161 See Walz v. Tax Comm'n, 397 U.S. 664, 668-69 (1970); Everson v. Board of Educ., 330 U.S. 1, 18 (1947). For a critical discussion, see John T. Valauri, The Concept of Neutrality in Establishment Clause Doctrine, 48 U. PITT. L. REV. 83 (1986).

162 See Board of Educ. v. Mergens, 110 S. Ct. 2356, 2370-71 (1990); Lemon v. 
It is difficult to see how government could adopt a public policy on religious grounds without offending this construction. ${ }^{163}$ Thus laws or measures that would otherwise be permissible have nonetheless been invalidated when the Court has discerned a religious rationale or purpose. ${ }^{164}$ To be sure, the principles of neutrality and governmental secularism are themselves subject to multiple and sometimes conflicting interpretations; ${ }^{165}$ consequently, the implementation of these principles has been chaotic. ${ }^{166}$ But the basic principles, with their implicit prohibition against governmental reliance on religious grounds, have remained central to the Court's Establishment Clause jurisprudence.

In recent years, moreover, the Court has developed, as a kind of gloss on the neutrality and secularism requirements, the corollary idea that government is constitutionally prohibited from acting in ways that are intended to endorse or disapprove of religion, or that will be perceived as doing so. ${ }^{167}$ The "no endorsement" doctrine makes clearer what was perhaps only implicit in earlier doctrine-the Establishment Clause forbids governmental reliance on religious justifications for public policies. How, after all, could government embrace and act upon a religious rationale without sending a message or creating a perception that it has endorsed religion?

\section{B. The Prohibitory Interpretation and the Religious Justification}

In view of the widespread acceptance of the prohibitory interpretation, the disappearance from legal and academic discourse of the religious justification for religious liberty is understandable. Why would judges or legal scholars use a religious rationale to justify a constitutional policy whose central meaning is that public policies cannot be based on religious rationales? The religious

Kurtzman, 403 U.S. 602, 612-13 (1971).

${ }^{163} \mathrm{Cf}$. Merel, supra note 140, at 809 ("The identification of a secular purpose necessarily depends upon the determination of what is not, in fact, religious.").

164 See, e.g., Wallace v. Jaffree, 472 U.S. 38 (1985) (declaring "moment of silence" law invalid because, although permissible in substance, it was adopted for a religious purpose).

165 See Board of Educ. v. Allen, 392 U.S. 236, 249 (1968) (Harlan, J., concurring) ("Neutrality is . . . a coat of many colors."). John Valauri has argued convincingly that "[t] he concept of neutrality [in establishment jurisprudence] is . . . irresolvably and multiply ambiguous." Valauri, supra note 161, at 93 . For my own analysis of several different versions of neutrality, see Steven D. Smith, The Restoration of Tolerance, 78 CAL. L. REV. 305, 313-26 (1990).

166 See infra notes 298-300 and accompanying text.

${ }^{167}$ See infra parts IV.F, V.A. 
justification for religious liberty has come to seem incompatible with religious freedom itself: our constitutional commitment to religious freedom has been disabled from acknowledging the principal historical justification for its existence.

At least one contemporary scholar, however, has attempted to restate the religious justification in terms that might make it suitable for current use without offending the prohibitory interpretation. ${ }^{168}$ The essence of Michael McConnell's argument is that "the liberal state . . . cannot reject in principle the possibility that a religion may be true; and if true, religious claims are of a higher order than anything in statecraft." 169 He elaborates:

[R]eligious claims-if true-are prior to and of greater dignity than the claims of the state. If there is a God, His authority necessarily transcends the authority of nations; that, in part is what we mean by "God." For the state to maintain that its authority is in all matters supreme would be to deny the possibility that a transcendent authority could exist. ${ }^{170}$

McConnell's argument uses language reminiscent of Madison's Memorial and Remonstrance, and almost amounts to a presentation of the "priority claim" of the religious justification. ${ }^{171}$ The crucial difference, as the italicized language makes clear, is that McConnell's priority claim is not offered affirmatively as something that the state should positively acknowledge, but rather conditionally as something that might be true and that the liberal state can neither affirm nor reject. ${ }^{172}$ In a sense, therefore, McConnell is asking the state to adopt an agnostic position toward religion, ${ }^{173}$

${ }^{168}$ See Michael W. McConnell, Accommodation of Religion, 1985 SUP. CT. REV. 1, 1524. McConnell offers a number of rationales for affording religion special constitutional treatment, including the rehabilitated religious justification.

${ }^{169} \mathrm{Id}$. at 15 .

${ }^{170} \mathrm{Id}$. (emphasis added).

171 See supra notes $48-49$ and accompanying text.

172 The conditional character of the argument is retained in a more recent presentation:

While the government is powerless and incompetent to determine what particular conception of the divine is authoritative, the free exercise clause stands as a recognition that such divine authority may exist and, if it exists, has a rightful claim on the allegiance of believers who happen to be American citizens.

McConnell, supra note 32, at 1516 (emphasis added).

${ }^{173}$ In a more recent article, McConnell himself suggests the appropriateness of this characterization. Comparing the issues raised by governmental funding of abortion and of religious education, McConnell observes that Roe $v$. Wade seems to require "governmental agnosticism about the morality or immorality of abortion." 
to refrain from embracing either theism or atheism. Nonetheless, from this position of public agnosticism, McConnell argues for the conclusion that would follow from a position of public theism: the state should accommodate citizens' claims when those claims invoke a divine or transcendent authority. In this way, McConnell's argument can be understood as an attempt to rehabilitate and reassert the religious justification without asking the state to accept any religious beliefs or premises. ${ }^{174}$

The stance that McConnell urges upon the state-public agnosticism-seems compatible with the prohibitory interpretation of religious freedom. The difficult question, however, is whether a position of public agnosticism can persuasively justify a conclusion favoring special constitutional treatment for religion. McConnell maintains that because religious beliefs might be true, and because the state cannot pronounce them false, the state must proceed as if these beliefs are true. But the logic might just as well run the other way: religious beliefs might be false, and the state cannot pronounce them true; therefore, the state should proceed as if those beliefs are false.

Upon reflection, the second conclusion seems more plausible, at least for a genuinely agnostic state. The problem with McConnell's position is an implicit and dubious allocation of the burden of persuasion. With regard to the question whether religion should receive special constitutional treatment, ḾcConnell implicitly assigns the burden of persuasion to the entity that might deny such treatment, i.e. the state. If government cannot determine the truthfulness or validity of religious claims, then the burden has not been carried and religion receives special treatment. But why should the burden of persuasion be assigned in this way? Normally,

Michael W. McConnell, The Selective Funding Problem: Abortions and Religious Schools, 104 HARV. L. REV. 989, 994 (1991). He goes on to suggest that a posture of governmental agnosticism toward abortion

is for all practical purposes identical to the posture toward religion prescribed by the free exercise and establishment clauses of the first amendment. The government may not legislate on the presupposition that religion in general, or any religion in particular, is correct or salutary, nor on the belief that religion is false or pernicious.

Id. at 995 .

${ }^{174} \mathrm{McC}$ Connell does not explicitly state that his argument is being offered for this purpose, and it is possible that he would simply reject the prohibitory interpretation. The analysis that follows suggests that the argument is more cogent if understood in this way, but, of course, it would then be unacceptable to those who embrace the prohibitory interpretation. 
one would suppose, that burden is properly assigned to the institution or interest asking for special treatment, not to those who oppose such treatment. It would be odd for a lobbyist to argue that the legislature must adopt a particular program unless the program's opponents can prove it undesirable. Likewise, plaintiffs in civil litigation normally would not expect to obtain a judgment simply by arguing that a remedy would be warranted if their allegations were true and that the defendants have failed to disprove those allegations. Why then does McConnell effectively assign the burden of proof to those who would deny special constitutional treatment to religion?

McConnell's brief discussion of the issue does not directly address this question, but answers can be imagined. One possibility is that the allocation of the burden in favor of special status for religion is justified because of an antecedent probability: it is more likely than not that the pertinent religious claims are true, so although the state cannot definitively pronounce these claims either true or false, it should act as if they are true. This position seems sensible if its premise-that the pertinent religious claims are probably true-is accepted. But that, of course, is the problem; not only is the premise controversial, it also violates the prohibitory interpretation of religious freedom. If religious freedom means that government cannot act on the ground that a religious belief is true, then government surely cannot circumvent the prohibition merely by assuming that a religious belief is probably true.

Another possibility is that McConnell's allocation of the burden of persuasion is warranted on the basis of something like Pascal's Wager. ${ }^{175}$ In Pascal's famous argument, an individual is faced with an inescapable choice: she must either believe in God or decline to believe in God. There is no adequate rational proof, the argument assumes, that can demonstrate the existence or nonexistence of God. Thus, "a coin is being spun which will come down heads or tails. How will you wager? Reason cannot make you choose either, reason cannot prove either wrong." 176

In these circumstances, Pascal contended, the chooser must consider the stakes-the relative risks and benefits of the alternative choices. When one looks at the problem in this way, he argued, the rational choice is to believe in God. If the individual chooses to

175 See Blaise Pascal, PENSEes 149-54 (A.J. Krailsheimer trans., 1966).

${ }^{176} \mathrm{Id}$. at 150 . 
believe, yet it turns out there is no God, she loses very little. ${ }^{177}$ But if her choice is right, she gains eternal salvation. Conversely, if she chooses not to believe, and in fact there is no God, she gains very little (beyond the satisfaction of holding a correct belief). However, if her choice is incorrect the cost is monumental; she loses her salvation. "This is conclusive and if men are capable of any truth this is it." 178

McConnell's argument evinces a similar logic. The liberal state is in the position of Pascal's chooser; it cannot determine whether there is or is not a transcendent authority. But if such an authority exists, it would be wrong and unwise in the extreme to flout the authority's dictates. Hence, when a religious believer presents a claim invoking divine authority, the state should err on the side of safety by accommodating the believer's demands.

If this is the basis of McConnell's argument, however, then it is vulnerable to the same objection that can be made to Pascal's argument (at least if Pascal is understood as attempting to convince agnostics to accept religious faith). Antony Flew points out that Pascal's Wager works only if one assumes that the alternatives he lists-belief in the Christian God (accompanied by eternal salvation if the belief is correct) or rejection of such belief (accompanied by eternal damnation if God does exist)-are the only ones available. ${ }^{179}$ But, he explains:

${ }^{177}$ She might lose the benefit of being free to live a kind of life-a hedonistic life, perhaps-that her belief in God forbids. In Pascal's view, at least, this would be no great loss. See id. at 153 ("It is true you will not enjoy noxious pleasures, glory and good living, but will you not have others? .. I I tell you that you will gain even in this life ....”).

${ }^{178}$ Id. at 152. This description, I should note, may not accurately reflect the real purpose of Pascal's argument. Read carefully, the argument does not seem intended to convince someone who is genuinely undecided, or perhaps indifferent, to believe in God. Rather, the argument seems directed toward someone who may already be inclined to believe on other grounds such as faith, Scripture, or religious experience (all of which Pascal alludes to in the course of the argument), but who is hesitating because of the concern that religious belief is contrary to reason. Pascal seemingly wants to reassure this person that it is not "sinning against reason" to believe in God. See id. at 151. He implies that the believer does not base religious faith on reason or calculation, but if someone insists on evaluating religious faith in those terms, then it is perfectly rational to hold religious faith. Understood in this way, Pascal's argument avoids the objection that one cannot simply choose to believe because belief is not a matter of will or choice. See Alasdair MacIntyre, The Debate about God: Victorian Relevance and Contemporary Irrelevance, in ALASDAIR MACINTYRE \& PAUL RICOEUR, THE RELIGIOUS SIGNIFICANCE OF ATHEISM 1, 22-23 (1969).

179 See ANTONY Flew, THE PRESUMPTION OF ATHEISM 66-68 (1976). 
In thus limiting our betting choices to two, Pascal makes a gigantic, unwarranted, and false assumption ....

-...

... [W] [hat we have to recognize, in assessing Pascal's Wager itself, is that there is no limit to the total of theoretically possible, mutually exclusive, Hell-threatening cosmic systems. In particular, for every such system demanding one way of life, and threatening all others, there is a possible system threatening just that way of life, and rewarding all others. For every possible way of life, there are possible systems demanding and penalizing that way of life. And so on. Catholicism threatens with endless torture all those outside the true Mystical Body of Christ; but it is just as conceivable that there is a hidden God (Deus absconditus!) who will consign all and only Catholics to the fate which they so easily approve for others. Since there is thus an unlimited range of pairs of possible transcendental religious systems, encouraging and threatening every conceivable way of life with exactly the same inordinate rewards and punishments, such transcendentally backed threats cannot provide even a prudential reason to choose one way of life rather than another. ${ }^{180}$

Flew's disparaging attitude toward Catholicism may be unfair. Moreover, his argument, based on the mere conceivability of an infinite variety of cosmic systems, may miss the point for individuals who believe there is some antecedent probability that certain beliefs are better candidates for acceptance than others. If the live choice $^{181}$ for me is whether or not to accept Christianity, I am not likely to be dissuaded by the suggestion that conceivably there is a deity who will punish only Christians and reward everyone else. That possibility may indeed be conceivable, but for me there is no reason to take it seriously.

Despite these deficiencies, Flew's criticism contains a valid point: Pascal's argument tacitly assumes that particular options in belief are already regarded as viable or antecedently probable, and that other possible beliefs, although perhaps conceivable, are not regarded as viable. Without this assumption, the argument loses its force.

Similarly, McConnell's argument-the state should respect religious claims because it cannot pronounce them false-will have

${ }^{180} \mathrm{Id}$.

181 For a discussion of the notion of live or genuine choices, see William James, The Will to Believe, NEW WORLD, June 1896, at 327, reprinted in WILLIAM JAMES, THE WRITINGS OF WILLIAM JAMES 717-18 (John J. McDermott ed., 1967). 
persuasive force only if we acknowledge an antecedent probability that the religious beliefs on which those claims depend may be true. Conversely, if an environmentalist Trekkie claims that concerned visitors from a wiser planet will wipe out human life unless we immediately cease all oil drilling and nuclear power production, we are likely to ignore his claim even though we cannot demonstrate its falsity. Although these claims are similar in form-each presents a demand we would want to grant if the underlying premise is true, and we cannot be certain whether the underlying premise really is true-it would not be irrational to treat them differently. In this country, as noted above, religious belief is widespread; belief in paternalistic Vulcans who want to supervise earthly affairs probably is not.

In short, if it were permissible to appeal to widely held religious beliefs, then claims invoking a transcendent authority would at least enjoy some antecedent probability, and McConnell's argument for accommodating religion might be cogent. The problem, of course, is that an appeal to religious beliefs violates the prohibitory interpretation of religious freedom. Thus, a genuine public agnosticism does not support special treatment of religion; only a slanted agnosticism predisposed to credit religious beliefs produces that result. ${ }^{182}$ In the end, McConnell's argument achieves plausibility only by relying upon tacit assumptions that transgress the prohibitory interpretation.

\section{G. An Illustrative Case: Jefferson's Statute Revisited}

The discussion to this point suggests that although our constitutional commitment to religious liberty was adopted largely on the basis of a religious justification, our current understanding of what religious freedom means has rendered that justification inadmissible in constitutional discourse. McConnell's agnosticism rationale, if understood as an attempt to reformulate the religious justification in a manner conforming to the prohibitory interpretation, is unpersuasive. Consequently, our commitment to religious freedom nullifies its own historical justification.

One way to illustrate this paradox is to apply it to a particular case. Jefferson's Virginia Act for Religious Freedom provides an

182 In this sense, there is at least a kernel of truth in Stephen Gey's hyperbolic claim that McConnell's position effects a "transformation of the state from a secular entity to a sectarian one." Gey, supra note 140, at 142. 
excellent example. This statute has been regarded as a landmark in the achievement of religious liberty. Martin Marty observes: "For those who like to speak of an 'Age of Constantine' that began in the fourth century, there is reason to regard the Virginia act as the key moment of the end of that age and the beginning of a new one." 183 The paradoxical quality of our interpretation of religious freedom is pointedly illustrated by the fact that if Jefferson's statute were challenged today under prevailing legal doctrine, it would seemingly be unconstitutional. Even more ironically, the statute would seemingly be unconstitutional as a violation of religious freedom.

The substantive section of Jefferson's statute provided:

That no man shall be compelled to frequent or support any religious worship, place or ministry whatsoever, nor shall be enforced, restrained, molested or burdened, in his body or goods, nor shall otherwise suffer on account of his religious opinions or belief; but that all men shall be free to profess, and by argument to maintain, their opinions in matters of religion, and that the same shall in no wise diminish, enlarge or affect their civil capacities. ${ }^{184}$

These substantive provisions seem constitutionally unobjectionable. As noted, however, the stated ground or premise for this enactment was that "almighty God hath created the mind free" and that any infringement of this God-given freedom is "a departure from the plan of the Holy author of our religion, who being Lord both of body and mind, yet chose not to propagate it by coercions on either, as was in his Almighty power to do ...."185 Under current establishment clause doctrine, Jefferson's statute would be unconstitutional if it sends a message endorsing religion. Does it?

The question is not entirely rhetorical. The current test is not whether a message of endorsement would be perceived by real fleshand-blood persons, but whether a "reasonable" or "objective" observer would perceive such a message. ${ }^{186}$ And, as it turns out, the perceptions of this fictitious observer sometimes differ dramatically from those of actual citizens and scholars. ${ }^{187}$ Still, it is hard

${ }^{183}$ Martin E. Marty, The Virginia Statute Two Hundred Years Later, in VIRGINIA STATUTE, supra note 19 , at $1,2$.

184 Virginia Act for Religious Freedom, VA. CODE ANN. § 57-1 (Michie 1986), reprinted in VIRGINIA STATUTE, supre note 19, at xvii.

185 Id. at xvii.

${ }^{186}$ See County of Allegheny v. ALCLU, 492 U.S. 573, 631 (1989) (O'Connor, J., concurring).

${ }^{187}$ For example, in Lynch v. Donnelly, 465 U.S. 668, 687-93 (1984) (O'Connor, 
to see how even the most astutely "objective" of observers could fail to find an endorsement of religion in Jefferson's statute. The religious language in the preamble appears to be substantive and justificatory in character; hence, unlike some religious language, it cannot easily be passed off as serving a merely ceremonious or solemnizing function. ${ }^{188}$

Jefferson's statute can be contrasted in this respect with the Alabama "moment of silence" law struck down in Wallace $v$. Jaffree. ${ }^{189}$ The statute authorized a moment of silence for meditation or voluntary prayer. Although some Justices indicated that such a law would be permissible in its substance, ${ }^{190}$ the statute was found to be infirm in large part because the words "voluntary prayer" were seen as endorsing religion. ${ }^{191}$ If the relatively innocuous language of the Alabama law impermissibly endorsed religion, then Jefferson's statute positively reeks with offensive endorsements.

The deeper problem with Jefferson's statute, however, is not just that its language endorses religion. The objectionable language might be removed or perhaps ignored, or the "no endorsement" test might lose favor with the judiciary. But the essential problem would remain: if the statute's preamble accurately expressed the reasons for Virginia's adoption of the statute, then even if the law could be cleansed of its messages of endorsement it would still offend the

J., concurring), Justice O'Connor concluded that a creche included in a Christmas display would not send a message endorsing religion. Mark Tushnet points out that this conclusion "came as a surprise to most Jews." Tushnet, supra note 140, at 712 n.52. Similarly, O'Connor indicated that the motto on coins- "In God We Trust"does not communicate a message of endorsement. See Lynch, 465 U.S. at 692-93. But Jesse Choper contends that "[ $t]$ he placement of 'In God We Trust' on coins and currency ... seems to have no real purpose other than a religious one." Jesse $H$. Choper, The Free Exercise Clause: A Structural Overview and an Appraisal of Recent Developments, 27 WM. \& MARY L. REV. 943, 947 (1986).

${ }^{188}$ Justice $O^{\prime}$ Connor has argued that many traditional religious symbols and practices do not endorse religion but instead serve "the legitimate secular purposes of solemnizing public occasions, expressing confidence in the future, and encouraging the recognition of what is worthy of appreciation in society." Lynch, $465 \mathrm{U} . \mathrm{S}$ at 693 (O'Connor, J., concurring). I have previously argued that this kind of analysis is based upon a false dichotomy. See Smith, supra note 155, at 281-82, 324.

189472 U.S. 38 (1985).

${ }^{190}$ See id. at 59, 62 (Powell, J., concurring); id. at 72-73 (O'Connor, J., concurring).

191 The words "or voluntary prayer" had been added, in the course of a larger amendment, to an earlier statute authorizing a moment of silence "for meditation." The majority and Justice O'Connor emphasized the addition of these words in concluding that the law endorsed religion. See id. at 58-59; id. at 77-78 (O'Connor, J., concurring). 
prohibitory interpretation of religious freedom because it would have been adopted on the basis of religious beliefs. ${ }^{192}$ In fact, it is likely that the preamble correctly affirms a religious basis for the statute. After all, the adoption of Jefferson's statute was the culmination of the debate over the defeated Assessments Bill. And the resistance to that bill was asserted on pervasively religious grounds, whether expressed in the biblical language of the Separatist Baptists or in the more Presbyterian terms of natural religion, as in Madison's Memorial and Remonstrance. ${ }^{193}$ Thus, under either the "no endorsement" test or the more general prohibitory interpretation, of which the "no endorsement" test is only one expression, Jefferson's statute would be difficult to sustain today.

The probable unconstitutionality of this landmark of religious freedom illustrates the self-canceling quality of our present constitutional commitment to religious freedom. Even so, one may view this result as an interesting anomaly, but not a practical problem. Although Jefferson's statute might be unconstitutional under current doctrine, a law similar in substance might be sustained if the preamble were deleted and the religious purpose replaced by a nonreligious rationale. That possibility raises a crucial question: is the religious justification indispensable? Is there, in other words, an adequate nonreligious rationale for giving special constitutional protection to religious freedom?

\section{GAN the Religious Justification be REPLACED?}

The foregoing analysis has described the process by which the constitutional commitment to religious liberty has canceled out its own historical justification. As suggested, however, that process might be viewed as manifesting a conceptual curiosity, but not as posing a realistic threat to the commitment itself. If the religious justification for religious freedom has been rendered inadmissible, can we not simply replace it with a currently acceptable nonreligious rationale? Or, failing that, might we not just rely upon the text of the First Amendment as a sufficient justification for preserving the constitutional right to religious freedom?

Although rarely giving sustained attention to the problem of supplying a contemporary rationale for religious freedom, ${ }^{194}$

192 See Dreisbach, supra note 50, at 187-88.

193 See supra notes $43-47$ and accompanying text.

194 See John H. Garvey, Free Exercise and the Values of Religious Liberty, 18 CoNN. 
twentieth-century courts and commentators have offered a variety of potential nonreligious successors to the religious justification. The most common of these proposed rationales are the following: the civic virtue rationale argues that religion deserves special constitutional protection because it instills in citizens the moral values or traits of character necessary in a democratic social order; ${ }^{195}$ the personal autonomy rationale asserts that religious freedom is warranted because of the importance of religion to matters of personal choice and identity; ${ }^{196}$ the pluralism rationale emphasizes the importance of religious freedom in ensuring a diversity of faiths, thereby strengthening American pluralism; ${ }^{197}$ the civil strife rationale argues that religious freedom is valuable in helping to curb the dissension and social conflict that issues of religion have historically provoked; ${ }^{198}$ and the nonalienation rationale suggests that religious freedom helps to avoid offending citizens who adhere to minority religious faiths or to none at all, thus helping all citizens to feel like full members of the political community. 199

These rationales have been subjected to powerful criticisms, and the following analysis reviews the central ones. The purpose is not to show that the nonreligious rationales are utterly untenable. Obviously, some people do find these rationales to be more or less persuasive. Moreover, some of the rationales were likely influential during the founding period in securing the commitment to religious liberty. ${ }^{200}$

At that time, however, the nonreligious rationales supplemented the religious justification. Today, by contrast, they are forced to do the work of justification on their own. The following analysis

L. REv. 779, 779-82 (1986). According to Michael Smith, " [I]ittle has been written on the Supreme Court's present-day policy justifications for the special constitutional place of religion," and the articles written "do not treat the subject systematically." Smith, supra note 15 , at 87.

${ }^{195}$ See infra part IV.B.

196 See infra part IV.C.

197 See infra part IV.D.

198 See infra part IV.E.

${ }^{199}$ See infra part IV.F. There are other possible rationales, along with variations of the rationales listed. However, those listed appear to be the most common and, presumptively, the most widely persuasive.

${ }^{200}$ See supra notes 54-68 and accompanying text (discussing the civil peace rationale in the founding period); see also CHRISTOPHER F. MOONEY, PUBLIC VIRTUE: LAW AND THE SOCIAL CHARACTER OF RELIGION 24-25 (1986) (discussing the founders' view that religion was necessary to promote civic virtue). 
suggests that while these rationales cannot be rejected out of hand, they are probably too weak and vulnerable to sustain a strong constitutional commitment to religious liberty. This conclusion is necessarily tentative; there is no precise scale for determining either how persuasive a constitutional justification needs to be or how persuasive a particular rationale actually is. However, given the welter of activities and interests for which special constitutional protection might be sought, the conferral of special constitutional status upon a particular interest or activity presumably demands a comparatively powerful justification. The weighty objections to which the common nonreligious rationales are liable make it doubtful that they are capable of meeting this demand.

\section{A. The Requirements of an Adequate Rationale}

Although it is impossible to say just how powerful a constitutional justification needs to be, one can at least describe the general characteristics of a rationale adequate to justify special constitutional protection for religious freedom. Such a rationale should exhibit three qualities: distinctiveness, plausibility, and cogency.

The distinctiveness requirement demands that a rationale identify something distinctive about religion that explains why religion deserves a level of legal protection that most other human interests and activities do not receive. ${ }^{201}$ For example, a rationale which merely asserts that many citizens care deeply about religion is plainly inadequate. It may be true that many people care deeply about religion, but, of course, many people also care passionately about baseball, or automobiles, or the freedom to pursue a chosen occupation or profession. The essential question is why religion deserves a special constitutional protection that these other interests do not receive.

This distinctiveness requirement should not be made unduly demanding. It is not necessary that a rationale identify a characteristic of religion that no other interest or activity shares in any degree. It should be sufficient to show that religion serves an important function more effectively or in a more essential way than

201 Free speech theorists have confronted a similar question in trying to explain why expression deserves special constitutional protection. See, e.g., Lawrence Alexander \& Paul Horton, The Impossibility of a Free Speech Principle, 78 Nw. U. L. REV. 1319, 1347-49 (1983) (noting that attempts to justify special protection for speech on the ground that free speech furthers autonomy fail to show why other autonomy-enhancing activities should not enjoy similar status). 
other interests or activities do; such a showing would serve to distinguish religion from other candidates for special protection. For example, a rationale asserting that more people care deeply about religion than about other things like baseball or business would seem to satisfy the distinctiveness requirement.

This sort of attempt to distinguish religion, however, might run afoul of the plausibility requirement. This requirement simply makes the obvious point that the claims upon which a proposed rationale depends must be credible. A formally beautiful but factually unpersuasive rationale is of little help.

Finally, a rationale must meet the cogency requirement. It must credibly explain not only how religion is distinctive, but how it is distinctive in a way that calls for a constitutional principle forbidding governmental regulation or interference in matters of religion. However plausible, a rationale that fails to satisfy the cogency requirement would amount to nothing more than a compelling non sequitur.

The following analysis tests the commonly proposed nonreligious rationales against these three requirements, showing that all encounter serious problems.

\section{B. The Civic Virtue Rationale}

The civic virtue rationale contends that religion is essential to our republic because it helps to inculcate in citizens the moral character necessary to a democratic society. ${ }^{202}$ This rationale

202 One version of this rationale suggests that although some people-perhaps those more enlightened or educated-can live moral lives without the support of religion, the masses need religion as a foundation for virtue. This idea is suggested in George Washington's Farewell Address:

Of all the dispositions and habits which lead to political prosperity, religion and morality are indispensable supports. . . . Whatever may be conceded to the influence of refined education on minds of peculiar structure, reason and experience both forbid us to expect that national morality can prevail in exclusion of religious principle.

George Washington, Farewell Address (Sept. 17, 1796), reprinted in ADAMS \& EMMERICH, supra note 14, at 114.

In a more philosophical version, it may be argued that no adequate non-religious ground for ethics exists. See J.D. Goldsworthy, God or Mackie? The Dilemma of Secular Moral Philosophy, 30 AM. J. JuRIs. 43 (1985); Arthur A. Leff, Unspeakable Ethics, Unnatural Law, 1979 DUKE L.J. 1229. In one or another version, the civic virtue rationale is common in modern efforts to justify religious liberty. For examples, see McConnell, supra note 168, at 16-19; Alan Schwarz, No Imposition of Religion: The Establishment Clause Value, 77 YALE L.J. 692, 713 (1968); Charles Taylor, Religion in a Free Society, in ARTICLES OF FAITH, supra note 26, at 93. 
immediately prompts an objection based on the distinctiveness requirement. It may be true that religion instills moral character, but so do schools and families, not to mention a host of other institutions, such as scouting groups, civic organizations, service clubs, and athletic leagues. Mark Tushnet remarks: "Religion may now be one among several methods of inculcating civic virtue, rather than a necessary method ...."203 Why then should religion be singled out for special constitutional treatment?

One response to this objection asserts that religion, although not the only source of moral character, is nonetheless the most important source, and perhaps even an indispensable one, in our society. ${ }^{204}$ This contention, while possibly satisfying the distinctiveness requirement, raises questions of plausibility. Some critics doubt that religion is an essential source of moral character. ${ }^{205}$ Indeed, some argue that religion tends to produce authoritarian character traits that are incompatible with the ethos of a democratic society. Stephen Gey insists that "the very structure of religious ideas and practice are contrary to the mode of thought necessary to foster democratic self-governance" and that "the authoritarian and

${ }^{203}$ Mark V. Tushnet, The Emerging Principle of Accommodation of Religion (Dubitante), 76 GEO. L.J. 1691, 1696 (1988); see also William P. Marshall, The Case Against the Constitutionally Compelled Free Exercise Exemption, 40 CASE W. RES. L. REV. $357,380-82$ (1989-90) (stating that "religion does not lay claim to a monopoly in the inculcation of civic virtues").

204 See REICHLEY, supra note 89, at 341-50.

205 Based on survey research studying religiosity among Americans and correlating such religiosity with behavior "related to lying, cheating, pilferage, and non-reporting of theft," George Gallup, Jr. reported in 1984 that "little difference is found in the ethical views and behavior of the unchurched and the churched." THE GalluP REPORT, REPORT NO. 222, RELIGION IN AMERICA 19 (1984). With respect to the more philosophical claim that no intellectually adequate ethics can be developed without incorporating religious premises, see supra note 202, one commentator argues:

We know that God and the action of God are not needed as logical underpinning of any coherent morality or fundamental law. Whether we follow J. S. Mill in deriving a perfectly adequate and humane morality from the simple fact that people attempt to obtain happiness, Immanuel Kant in pegging the working out of morality from the simple imperative to be moral, or H. L. A. Hart in deriving a perfectly usable fundamental "natural law" from the mere attempt to survive in human bodies with human needs, we can deduce most of the morality that religion has taught from very simple observations. . . . We need no "Dominus dixit" to back up our fundamental moral convictions.

Lisa Newton, Divine Sanction and Legal Authority: Religion and the Infrastructure of the Law, in RELIGION, MORALTTY, AND THE LAW: NOMOS XXX 179, 179 (J. Roland Pennock \& John W. Chapman eds., 1988). 
undemocratic nature of religion is inconsistent with the antiauthoritarian and democratic biases of the Constitution." ${ }^{206}$

Even if the civic virtue rationale can fulfill the distinctiveness and plausibility requirements, it remains seriously vulnerable, however, to the requirement of cogency. Suppose we assume that religion is an especially important factor in shaping moral character. Why does it follow that religion should be insulated against governmental regulation? One might credibly argue that exactly the opposite conclusion is warranted-that state supervision is appropriate precisely because character formation is such a vital social function. In other contexts, at least, this would be the natural conclusion. Thus, the importance of character formation is usually taken as an argument for rather than against maintaining statesponsored and state-regulated schools. ${ }^{207}$ It is also viewed as a reason supporting public supervision of student expression. ${ }^{208}$ The same reasoning can, and sometimes does, support state interference with religious institutions that are viewed as inculcating moral values of which society does not approve. ${ }^{209}$ Hence, even

${ }^{206}$ Gey, supra note 140, at 178, 184; see also Lynne Henderson, Authoritarianism and the Rule of Law, 66 IND. L.J. 379, 387 (1991) (suggesting that religion need not but is likely to produce authoritarianism). See generally Gey, supra note 140, at 172-86. Gallup's research contradicted the view that religious faith produces authoritarianism, suggesting that persons who are "highly spiritually committed" also "tend to be more tolerant of persons of different races and religions than are those who are less spiritually committed." THE GALLUP REPORT, supra note 205, at 18.

${ }^{207}$ See, e.g., Ambach v. Norwick, 441 U.S. 68, 76 (1979) (recognizing the "importance of public schools in the preparation of individuals for participation as citizens"); Brown v. Board of Educ., 347 U.S. 483, 493 (1954) ("Compulsory school attendance laws and the great expenditures for education both demonstrate our recognition of the importance of education to our democratic society. . . . It is the very foundation of good citizenship.").

${ }_{208}$ See, e.g., Hazelwood Sch. Dist. v. Kuhlmeier, 484 U.S. 260, 266, $270-73$ (1988) (stating that schools may restrain student expression in order to promote cultural values and prepare students for later professional training). In Bethel School District v. Fraser, 478 U.S. 675 (1986), the Supreme Court declared that "'[p]ublic education must prepare pupils for citizenship in the Republic. . . . It must inculcate the habits and manners of civility as values in themselves conducive to happiness and as indispensable to the practice of self-government . . . '" Id. at 681 (quoting CHARLES A. BEARD \& MARY R. BEARD, NEW BASIC HISTORY OF THE UNITED STATES 228 (1968)). From this premise the Court concluded that the Constitution permits students' rights to free expression to be balanced against "society's countervailing interest in teaching students the boundaries of socially appropriate behavior." Id.

${ }^{209}$ See, e.g., Ohio Civil Rights Comm'n v. Dayton Christian Sch., 477 U.S. 619 (1986) (permitting state agency to proceed against Christian schools in connection with alleged civil rights violations); Bob Jones Univ. v. United States, 461 U.S. 574 (1983) (upholding withdrawal of tax exempt status from religious schools because of school policies forbidding interracial dating). 
if religion has a uniquely important role in instilling moral values, it need not follow that religion should receive special constitutional protection against state interference. ${ }^{210}$

\section{G. The Personal Autonomy Rationale}

The personal autonomy rationale contends that religious belief and practice are important to a person's sense of who she is and what kind of person she wants to be; the freedom to be oneself entails the freedom to hold religious beliefs and to act in accordance with those beliefs. ${ }^{211}$ The objections to this rationale and the responses to those objections follow a familiar course. The initial criticism is that the personal autonomy rationale fails the distinctiveness test. Religious beliefs and practices may be important to personal identity, but of course many other aspects of belief, choice, heritage, lifestyle, and personality are also vital to a person's sense of who she is. ${ }^{212}$

${ }^{210}$ Indeed, William Marshall goes further, arguing that to grant religion special treatment over other institutions and belief systems that may influence character formation is to indulge in an unconstitutional favoritism. See Marshall, supra note 203, at 388-412. "By preferring religious belief systems over all others, including philosophical, moral, and political belief systems, [a religious] exemption [from regulation] offends the equality-of-ideas notion that is at the core of constitutional law." Id. at 411-12.

${ }^{211}$ Ira Lupu explains: "Rights of free exercise are quintessentially rights of autonomy. The right of religious liberty embraced in the clause protects interests in making and maintaining spiritual commitments, and in living in accord with one's deepest presuppositions about humankind and nature." Ira C. Lupu, Free Exercise Exemptions and Religious Institutions: The Case of Employment Discrimination, 67 B.U. L. REV. 391, 422 (1987); see also Alan E. Brownstein, Harmonizing the Heavenly and Earthly Spheres: The Fragmentation and Synthesis of Religion, Equality, and Speech in the Constitution, 51 OHIO. ST. L.J. 89, 95 (1990) ("[T] he free exercise of religion . . . is part of that basic autonomy of identity and self-creation which we preserve from state manipulation, not because of its utility to social organization, but because of its importance to the human condition."). Michael Sandel argues that this rationale for religious freedom is pervasive in liberal constitutional thinking. See Sandel, supra note 143, at 84-86. "By emphasizing the individual's right to choose his beliefs, [this rationale] points beyond religion to 'the broader perspective' of autonomy rights in general, including 'the rights of privacy and personhood." Id. at 87 (quoting LaURENCE H. TRIBE, AMERICAN ConSTTIUTIONAL. LaW 885 (1st ed. 1978)).

212 See, e.g., William P. Marshall, The Concept of Offensiveness in Establishment and Free Exercise Jurisprudence, 66 IND. L.J. 351, 361 n.56 (1991) (asserting that "the protection of matters essential to self-identity does not categorically distinguish religious from moral, philosophical, or political sensibilities. Religious beliefs are not the only types of beliefs that may be critical to one's self-identity."). In a similar analysis, referring to Simcha Goldman's religious duty to wear a yarmulke, John Garvey observes: 
A proponent of this rationale might rejoin by asserting that although a variety of factors impinge upon or help to constitute personal identity, religion is the most essential factor. ${ }^{213}$ In satisfying the distinctiveness requirement, however, this claim of centrality creates plausibility problems. ${ }^{214}$ Religious belief may be the most vital element in some persons' identities, yet it is doubtful this is true for all, or even most, individuals. A religious term (Christian, Jew, agnostic) may be no more important to a person's conception of who she is than other terms based on such diverse factors as personal relationships (mother, sister), profession (engineer, lawyer), race (Hispanic, Native American), political affiliation (Republican, Libertarian), special skills (violinist, gardener), socioeconomic status (yuppie, homeless), residence (New Yorker, Westerner), or individual habits, tastes, activities, interests, or loyalties (vegetarian, Cubs fan). ${ }^{215}$ If individuals could accurately rank such terms in order of importance to their identity, it is doubtful that the religious term would uniformly occupy first place. There are quite likely as many (Christian) yuppies as (yuppie) Christians. ${ }^{216}$

I might truthfully say that wearing a cowboy hat is important not just for my image, but to my very conception of self. If my claim were sincere, Goldman and I ought to get the same degree of protection for our autonomous choices. But Goldman's claim is constitutionally stronger, for a reason that goes beyond autonomy to some special value of religion.

Garvey, supra note 194 , at 791.

${ }^{213}$ Alan Brownstein notes "the unique nature of religious affiliation with regard to its impact on a person's sense of identity. Religion is a core part of one's sense of self. Other mutable attributes, such as political affiliation, are generally viewed as more tangential and ephemeral." Brownstein, supra note 211, at 147; see also Daniel O. Conkle, Toward a General Theory of the Establishment Clause, 82 Nw. U. L. REV. $1113,1164-66$ (1988) (claiming that an individual's acceptance of religious beliefs or self-conscious rejection of religious beliefs forces the individual to confront questions of who one is and what one's place in the world is, and thereby forms a necessary part of self-definition); Feigenson, supra note 152, at 74 (stating that religious identification is "often primary in adherents' conceptions of themselves and others").

${ }^{214}$ Cf. Smith, supra note 15, at 93-94 (questioning whether freedom of religion is more important to human personality than other things such as freedom of occupation).

215 See William P. Marshall, In Defense of Smith and Free Exercise Revisionism, $58 \mathrm{U}$. CHI. L. REV. 308, 320-21 (1991) ("[R]eligious belief cannot be qualitatively distinguished from other belief systems in a way that justifies special constitutional consideration. For example, bonds of ethnicity, interpersonal relationships, and social and political relationships as well as religion may be, and are, integral to an individual's self-identity." (footnotes omitted)).

${ }^{216}$ George Gallup reports: "The vast majority of us say that religion is important in our lives but few say it is the most important influence in their lives. . . . Americans 
Finally, even if religion is the most central element in personal identity, it may not provide a cogent justification for a special constitutional commitment to religious liberty. Personal autonomy concerns are already the subject of constitutional rights protecting freedoms of speech, belief, and association. These freedoms are not directed toward religious faith in particular, and their scope is not coextensive with that of rights to religious freedom as traditionally understood. ${ }^{217}$ But insofar as religious freedom is understood merely as a manifestation of the concern for personal autonomy, it is arguable that the freedoms of speech and belief already provide sufficient protection. In this vein, William Marshall calls for collapsing free exercise doctrine into free speech doctrine, ${ }^{218}$ and Ira Lupu argues that institutional free exercise claims ought to be treated as an aspect of freedom of association. ${ }^{219}$ These analyses suggest that when religious freedom is rationalized as a way to protect personal autonomy, the natural outcome is that religious freedom loses its claim to special or independent constitutional status.

\section{The Pluralism Rationale}

From the beginning of the republic, pluralism has been regarded as an important value in our democratic society. Pluralism may be embraced for its instrumental value in preventing tyranny and restraining factionalism ${ }^{220}$ or celebrated as desirable in itself. ${ }^{221}$ In any event, religious freedom is sometimes justified on the ground that it promotes American pluralism. ${ }^{222}$

say that religion is important, but they rank health, family, love and friends all ahead of religion." THE GALLUP REPORT, supra note 205, at 9.

${ }^{217}$ Rodney Smith points out that "while the protection of religious speech or expression is an element of religious liberty, it is both over- and under-inclusive as a doctrinal matter." Rodney K. Smith, Establishment Clause Analysis: A Liberly Maximizing Proposal, 4 NOTRE DAME J.L. ETHICs \& PUB. POL'Y 463, 483 (1990); see also Marshall, supra note 203, at 361 (observing that "many claims currently recognized as implicating free exercise protection do not easily fit within a [free] speech analysis").

${ }^{218}$ See Marshall, supra note 10.

219 See Lupu, supra note 211, at 431-43.

220 See THE FEDERALIST No. 10 (James Madison).

221 Judith Shklar has proposed "a defense of social diversity" which maintains that "a diversity of opinions and habits is not only to be endured but to be cherished and encouraged .... The range and the number of choices available and the mutual tolerance among those who choose conflicting paths are what determine the degree of freedom that the members of any modern society can be said to enjoy." JUDITH SHKLAR, LEGALISM 5-6 (1964).

${ }^{222}$ See, e.g., Walz v. Tax Comm'n, 397 U.S. 664, 689 (1970) (Brennan, J., 
From the outset this justification confronts a dilemma: in its most plausible version, the pluralism rationale does not satisfy the distinctiveness requirement, while in its more distinctive version the rationale is of doubtful plausibility. If the rationale merely asserts that religious diversity increases the degree of overall pluralism, then the rationale seems plausible, and, indeed, true by definition. But in this sense diversity in any sphere, whether intellectual, ethnic, cultural, economic, or recreational, will make society more pluralistic. Understood in this way, the pluralism rationale fails to explain why religion should be the subject of special constitutional protection. ${ }^{223}$ Conversely, if the rationale contends that religious diversity contributes to American pluralism in a more essential or valuable manner than diversity in other spheres of human life, problems of plausibility arise. Why is religious diversity uniquely valuable?

Some scholars suggest that religious pluralism provides the best practical assurance of religious freedom. ${ }^{224}$ This contention may be correct, but it is not responsive to (and is probably not intended to be responsive to) the present question. By assuming the importance of religious freedom, this rationale begs the question presently at issue. ${ }^{225}$ Conversely, if the claim is that religious diversity is more important than other kinds of diversity in resisting tyranny or political oppression generally, the claim is more dubious. One might support that claim by arguing that religion threatens democracy by cultivating authoritarian qualities in the citizenry ${ }^{226}$ and that religious pluralism reduces this threat by weakening the overall force of religion in society. ${ }^{227}$ But even accepting the first

concurring) (stating that religion "uniquely contribute[s] to the pluralism of American society"); J. Morris Clark, Comments on Some Policies Underlying the Constitutional Law of Religious Freedom, 64 MINN. L. REv. 453, 460 (1980) (arguing that allowing individuals to "do their own thing" in the religious context helps achieve pluralism in society); Stephen V. Monsma, The Neutrality Principle and a Pluralist Concept of Accommodation, in EQUAL SEPARATION, supra note 14, at 73, 84-90 (noting that separation of church and state "gives churches and other religious groups their proper due" which is critical to the achievement of a pluralistic society).

${ }^{223}$ See Marshall, supra note 203, at 381 ("The problem with the pluralism theory is ... that it is not an argument for special protection for religious exercise. The values inherent in pluralism are also advanced by the protection of non-religious groups.").

224 See Bradley, supra note 55, at 735-36, 740-47.

225 This does not mean, of course, that arguments linking religious pluralism to religious liberty are analytically flawed, but only that they do not address the question being considered here.

226 See supra note 206 and accompanying text.

${ }^{227}$ Robert Baird, the nineteenth-century church historian, attributed a design of 
premise of this argument, the notion that religious pluralism weakens religion is highly questionable. ${ }^{228}$ Alternatively, one might support the claim by arguing that a religious faction is more likely than political, economic, social, or ideological factions to attempt to seize control of government, and that religious pluralism is the best way to counter the threat of domination. Again, however, even if the premise of this argument is plausible, the argument at best supports a nonestablishment policy, ${ }^{229}$ not a general commitment to special constitutional protection which permits religion to flourish. In fact, on this view religion can be seen as an evil to be endured, rather than an activity to be encouraged through constitutional protection. ${ }^{230}$

The pluralism rationale encounters a further problem, which can be regarded as one either of plausibility or of cogency. Pluralism, despite its central role in much democratic theory, is hardly an unmitigated good. The benefit of pluralism is that it helps to avoid political tyranny; the cost is potentially impeding the realization of genuine political community. This possibility emerges unmistakably from Alasdair MacIntyre's modern classic After Virtue. MacIntyre shows how as older moral and religious traditions broke down, debates about issues such as the justness of war, the permissibility of abortion, and the tension between liberty and economic equality became what they are today: a chaos of conflicting and incommensurable assertions. ${ }^{231}$ In this context MacIntyre argues that

this sort to Thomas Jefferson. In Baird's view, Jefferson was "a very bitter enemy to Christianity, and we may even assume that he wished to see not only the Episcopal church separated from the state in Virginia, but the utter overthrow of everything in the shape of a church throughout the country." ROBERT BAIRD, RELIGION IN THE UNITED STATES OF AMERICA 230 (Arno Press 1969) (1844). With respect to Jefferson's Virginia Act for Religious Freedom, Baird opined that "it gave its author great satisfaction, not because it embodied the principles of eternal justice, but because by putting all religious sects on an equality, it seemed to degrade Christianity .... It was this that made the arch-infidel chuckle with satisfaction-not, we repeat, that the great principles embodied in the measure were right." Id. at 241.

${ }^{228}$ See, e.g., Murrin, supra note 26, at 25 (asserting that religious pluralism has strengthened religion in the United States).

${ }^{229}$ Even this conclusion is suspect. If one is truly worried about religion seizing control of government, perhaps the best preventive measure is for government to establish, operate, and supervise an official state church. This policy, of course, might provoke civil strife; at this point, the pluralism rationale overlaps with the civil strife rationale considered infra part IV.E.

230 See, e.g., Smith, supra note 15, at 112 (describing the view of Felix Frankfurter and Alexander Bickel that religion is a "public nuisance" that we are "bound to suffer" but should strive to replace).

${ }^{231}$ See MACINTYRE, supra note 135, at 6-7. 
genuine political community is impossible, ${ }^{232}$ and that politics, losing the dignity it enjoyed in classical thought, becomes a form of "civil war carried on by other means." 233 MacIntyre's diagnosis is controversial, of course, but that is just the point. His analysis demonstrates the vulnerability of a rationale that would justify religious freedom on the supposition that pluralism is an uncontroversial good.

\section{E. The Civil Strife Rationale}

The essence of the civil strife rationale suggests that religious freedom is important in preventing conflict over religious issues. ${ }^{234}$ Analysis of this rationale follows a recurrent pattern. The first objection is that religion is only one of a number of sources of civil strife; hence, the rationale fails to identify a distinguishing feature of religion that explains why religion requires special constitutional protection. ${ }^{235}$ The response to this objection asserts that while religion is not the only source of social conflict, it is a distinctively potent source of serious dissension. And the rejoinder insists that, at least in the context of our history, this claim is simply implausible. Michael Smith argues:

Our most divisive social issues since the constitutional revolution of 1937 have included the completion of industrial unionization in the late 1930s; McCarthyism in the early 1950s; the campaign for racial equality from the middle 1950 s onward; prolongation of the Vietnam War; and perhaps the Watergate scandal. It is perhaps too early to tell whether abortion and other sexual issues ...

232 See id. at 244.

233 Id. at 253.

234 Michael Snith observes that this is probably the most commonly offered justification for religious freedom in modern constitutional discourse. See Smith, supra note 15 , at 96.

235 Alan Schwarz made the point years ago, arguing with respect to the civil strife rationale that,

[t]o state this proposition is to ridicule it. If avoidance of strife were an independent constitutional value, no legislation could be adopted on any subject which aroused strong and divided feelings. Nor could a constitutional doctrine of strife avoidance be limited in application to legislation which exacerbates religious differences on the ground that those differences are more upsetting than any others. Patently, racial differences are today a far greater cause of strife than differences in religious belief. Would, then, the possibility of exacerbated racial controversy in and of itself invalidate open housing legislation?

Schwarz, supra note 202, at 711. 
should be added to this list. Even if so, they would be the only ones inherently involving religion..$^{236}$

One answer to this analysis might be that even if religion has not in fact been a distinctively divisive force in our society, the reason for this comparative tranquility is precisely that we have defused religion's divisive potential by giving constitutional protection to religious liberty. ${ }^{237}$ And if protection were abandoned, religion might become an explosive force in our society, just as it was in seventeenth-century England ${ }^{238}$ and as it is today in Ireland and India. This claim is inherently speculative, of course, and to the extent our history sheds light on it, the claim is dubious. The guarantees of religious liberty contained in the United States Constitution were not understood to apply to the states until the 1940 s. $^{239}$ During the first century-and-a-half of our republic, states were free to establish an official church, exclude religious dissenters from office, or otherwise engage in religious persecution. Nonetheless, no state maintained an established church after the $1830 s^{240}$ And although religious exclusion and persecution were hardly unknown, ${ }^{241}$ it is fair to say that issues directly implicating

${ }^{236}$ Smith, supra note 15, at 97; see also Michael W. McConnell, Political and Religious Disestablishment, 1986 B.Y.U. L. REV. 405, 413 ("Religious differences in this country have never generated the civil discord experienced in political conflicts over such issues as the Vietnam War, racial segregation, the Red Scare, unionization, or slavery.").

The rejoinder can also be stated in psychological terms:

It is not obvious why people should be supposed to be more contentious about their beliefs when they are rooted in some traditional religion than when they are rooted in a secular outlook. Indeed, the assumption that seems to underlie such a claim is [that] ... secular views [are] ... less capable than religious ones of generating loyalty or commitment. I see little reason to agree with such a view. Much in human experience indicates that it is false.

Strike, supra note 132 , at 487 .

${ }^{237}$ See Theodore Y. Blumoff, Disdain for the Lessons of History: Comments on Love and Power, 20 CAP. U. L. REv. 159, 181-82 (1991).

${ }^{238}$ But see infra note 287.

${ }^{239}$ See West Virginia State Bd. of Educ. v. Barnette, 319 U.S. 624 (1943).

240 Massachusetts was the last state to accept disestablishment, doing so in 1833. See ANSON P. STOKES \& LEO PFEFFER, CHURGH AND STATE IN THE UNITED STATES 7678 (1964).

241 See, e.g., EDWIN B. FIRMAGE \& RICHARD C. MANGRUM, ZION IN THE COURTS 49260 (1988) (discussing nineteenth-century persecution of Mormons); EDWIN S. GAUSTAD, A RELIGIOUS HISTORY OF AMERICA 208-17 (1966) (describing nineteenthcentury persecution of Catholics and Jews). 
religion were not as socially divisive as controversies about matters such as slavery and unionization.

In a broader sense, of course, many of our most controversial issues have implicated religious beliefs; slavery is an obvious example. ${ }^{242}$ This observation, however, generates another objection to the civil strife rationale: even if plausible, the rationale does not appear cogent. Let us assume that religious disagreements are especially disruptive to civil peace. Does it follow that a constitutional commitment to religious freedom will prevent or reduce such disruption? The question does not seem susceptible to a uniform answer that can be usefully embodied in constitutional doctrine because the effect of such a commitment will likely depend both on the nature of the particular religious disagreement and on the way in which religious freedom is understood.

For example, if in a religiously pluralistic community the issue is whether a particular denomination should enjoy monopoly status as the community's official religion, then one might plausibly conclude that a policy of nonestablishment, not necessarily entailing any more general commitment to religious liberty, would likely reduce the conflict that the struggle to achieve exclusive recognition might generate. Conversely, suppose the issue is whether students should pray aloud in public schools, and that a large majority of citizens favor the practice. ${ }^{243}$ Under these circumstances, a decision declaring the practice inconsistent with religious freedom may provoke more dissension than it quells. ${ }^{244}$ Finally, with respect to issues such as slavery or abortion where religious views are likely to be a source of tension, it is not clear that any interpretation of constitutional religious freedom could reduce the tension. Whatever stance the state may take toward religion, the disagreement is likely to persist. Thus, even if religion is a distinctively

242 See 2 SYDNEY E. AHLSTROM, A RELIGIOUS HiStORY OF THE AMERICAN PEOPLE 101-14 (1975).

${ }^{243}$ In 1963, 70\% of Americans disapproved of the Supreme Court's school prayer rulings. Over twenty years later, in $1984,64 \%$ of the population continued to favor a constitutional amendment permitting organized school prayer. See Joseph B. Tamney \& Stephen D. Johnson, Church-State Relations in the Eighties: Public Opinion in Middletown, 48 Soc. ANALYSIS 1, 5 (1987).

244 See Sandel, supra note 143, at 86-87. Sandel cites the school prayer decisions as cases in which the implementation of religious freedom provoked more strife than it prevented; others have agreed. See John S. Baker, Jr., The Religion Clauses Reconsidered: The Jaffree Case, 15 CUMB. L. REV. 125, 139 (1984); see also LEO PFEFFER, Religion, State AND THE BuRger Court 82-86 (1984) (describing the outrage generated by school prayer decisions). 
potent source of social strife, a policy of constitutional religious freedom is not necessarily an efficacious response to that danger. ${ }^{245}$

\section{F. The Nonalienation Rationale}

In comparison to the justifications previously discussed, the nonalienation rationale is of relatively recent vintage; it has been developed over the last decade in connection with the interpretation of the Establishment Clause as a prohibition against governmental messages that endorse or disapprove of religion. ${ }^{246}$ The nonalienation rationale can be viewed as an effort to avoid the failings of the rationales discussed above, and in particular those of the civil strife rationale. It may be implausible to rationalize decisions forbidding, for example, a municipal nativity scene or a "moment of silence" provision on the ground that these practices are likely to provoke civil strife which "strain[s] a political system to the breaking point." ${ }^{247}$ But it seems eminently plausible to assert that government involvement in or endorsement of religion may alienate or offend some citizens. Thus, the nonalienation rationale closely parallels the civil strife rationale, except that the feared evil has been scaled down. Where the older rationale suggested a danger of serious social disruption leading perhaps to political disintegration, the newer rationale envisions, at least in the short term, a more quiet withdrawal of some citizens from the political community because of their sense of second-class status. ${ }^{248}$

${ }^{245}$ Cf. Schwarz, supra note 202, at 711 (arguing that "prohibiting aid to religion does not avoid strife, it merely alters its source"); see also Michael A. Paulsen, Religion, Equality, and the Constitution: An Equal Protection Approach to Establishment Clause Adjudication, 61 NOTRE DAME L. REV. 311,347 (1986) ("The invalidation of a 'divisive' policy because of its supposed 'divisiveness' can be the most 'divisive' action of all." (footnote omitted)).

${ }^{246}$ See, e.g., County of Allegheny v. ACLU, 492 U.S. 573 (1989) (holding that the Establishment Clause prohibits the appearance of a government stance on religion); Lynch v. Donnelly, 465 U.S. 668, 687-93 (1984) (O'Connor, J., concurring) (arguing that government must not communicate a message of endorsement or disapproval of religion).

247 Walz v. Tax Comm'n, 397 U.S. 664, 694 (1970) (Harlan, J., concurring).

${ }^{248}$ For characteristic expressions of this rationale, see County of Allegheny, 492 U.S. at 595-97; id. at 625-27 (O'Connor, J., concurring); KENNETH L. KARST, BELONGING TO AMERICA 100-04 (1989); TRIBE, supra note 14, \$§ 14-15, at 1293-97; Feigenson, supra note 152 , at 55 . By diluting the projected evil, the newer rationale raises a question whether this evil is sufficient to justify a special constitutional right, even assuming other objections to the nonalienation rationale are overcome. Traditionally, the Constitution has not been understood to prohibit governmental actions that give 
Since the nonalienation rationale parallels the civil strife rationale, one would expect it to generate similar objections and responses, and it does. The first objection is that although governmental involvement in or endorsement of religion may alienate or offend some citizens, government involvement in any area of life or endorsement of any belief may have the same consequence. Government endorses free enterprise but not socialism, war against Iraq rather than continuation of nonmilitary sanctions or pacifism, policies of natural resource development over certain kinds of environmentalist policies. The public schools, at the insistence of the Supreme Court, sponsor the teaching of evolution but not of creationism. ${ }^{249}$ Any of these actions and messages may offend some citizens and cause them to feel like "outsiders." Thus, the simple fact that governmental endorsement of religion produces offense is not sufficient to make religion distinctive. ${ }^{250}$

Proponents of the rationale may argue that the offense and sense of exclusion arising from religious messages is more severe than that based on other kinds of governmental messages. ${ }^{251}$ Once again, this answer responds to the distinctiveness concern, but only at the cost of raising significant plausibility questions. Is it clear that citizens who are communists, pacifists, or fervent environmentalists feel less alienated than citizens who object to public displays containing menorahs or nativity scenes?

Even more importantly, the nonalienation rationale encounters serious difficulties with the cogency requirement. As with the civil strife rationale, the concern to avoid alienation does not appear to generate general principles that can be usefully embodied in constitutional law. Even though there may be a connection between religious freedom and the good or value of nonalienation, that connection is not necessary or uniform, but rather contingent on shifting and elusive cultural circumstances. Consequently, the

offense; indeed, even if government is violating the Constitution in a substantive way, citizens who merely claim they are offended by the action have not been regarded as having suffered a sufficient injury to claim standing to challenge the violation. See United States v. Richardson, 418 U.S. 166 (1974).

${ }^{249}$ See Edwards v. Aguillard, 482 U.S. 578 (1987); Epperson v. Arkansas, 393 U.S. 97 (1968).

250 See Marshall, supra note 212, at 358-63.

251 See, e.g., Conkle, supra note 213, at 1168 (noting that "the existing bonds of community can be severely weakened" by government endorsement of a religious belief). 
nonalienation rationale, while identifying a sensible desideratum for wise political policy, provides an infirm foundation for a general and judicially enforceable constitutional commitment.

This point can be clarified by imagining a hypothetical political community in which devotees of one religion, the "Baal-worshippers," constitute ninety percent of the population; the other ten percent are "Diana-worshippers." The Baal-worshippers tolerate the religion of Diana in the limited sense that they have not made it a criminal offense to practice that religion. But they believe that Diana worship is evil and offensive, and that they would be contaminated by close contact with the disciples of Diana. Or perhaps they believe that Baal would frown on any government that afforded infidels equal political status with his own disciples. Consequently, the community's constitution excludes Dianaworshippers from serving in public office. The constitution is similar in this respect to those of many American states before and for decades after the adoption of the First Amendment that used religious oath requirements or other restrictions to exclude nontheists, non-Christians, or sometimes non-Protestants from public office. $^{252}$

In this situation, will the adoption of a commitment to religious freedom reduce alienation by removing the barrier that excludes Diana-worshippers from office? Certainly such a commitment would help to assuage the severe sense of alienation experienced by Diana-worshippers. But if the result of admitting the Dianaworshippers to equal status is that Baal-worshippers, fearing spiritual contamination, feel compelled to withdraw from public office, then the overall degree of alienation-the sense of exclusion from public life on religious grounds-might well increase. Of course, one might still argue that religious freedom is the correct or just policy. If Baal-worshippers feel alienated, one might contend, it is their own fault for believing the way they do. ${ }^{253}$ Or one might excuse the alienation of Baal-worshippers by frankly asserting that theirs is a pernicious or unworthy faith. But one could hardly rely upon the desirability of reducing actual alienation as the

252 See Chester J. ANTIEAU et AL., Religion Under the STAte Constitutions 102-04 (1965).

253 Of course, the Baal-worshippers could have said the same thing all along to the Diana-worshippers. The statement is formally correct in both cases; indeed, it will always be formally correct to say that those who feel alienated on religious grounds would not feel so if they did not believe as they do. 
justification for this position because in this context religious freedom would likely increase overall alienation.

Under other circumstances, religious freedom would reduce overall alienation. If the percentage of Diana-worshippers increases, or if numerous Baal-worshippers abandon the belief that association with Diana-worshippers leads to spiritual contamination, then the balance might shift in favor of religious freedom. Likewise, in our society there are certain aspects of religious freedom that undoubtedly produce a clear net gain in political inclusion. For example, one could confidently suppose that the absence of an established church forestalls more alienation than it produces, even though a few citizens favoring an established church may feel alienated by nonestablishment. ${ }^{254}$ On many other issues, however, including school prayer, ${ }^{255}$ aid to parochial schools, and religious symbols in public displays, the balance of alienation is much harder to assess. 256

The problem is particularly complex because there is no assurance that the balance of alienation with respect to a given issue will be uniform through space and time. In a largely secular community, or a politically and religiously liberal community, a "Balanced-Treatment" statute requiring that creationism receive equal attention with evolution in the public school curriculum might produce more disaffection than it would relieve. ${ }^{257}$ Hardly anyone in this community, we may suppose, is alienated by the teaching of evolution anyway; but many students and their parents

${ }^{254}$ See Ladd, supra note 82 , at 28 (explaining that survey evidence shows that the essential notion of separation of church and state is "universally accepted" by Americans).

255 See supra note 243.

${ }^{256}$ One scholar notices:

[T]his problem of "at homeness" and alienation is inherently insoluble. Like it or not, the nature of governmental action is to take stands which some citizens will reject due to their religious scruples. ... For example, nonChristians are rankled by public nativity scenes. Very well. But who is more rankled by public schools these days than Catholics and fundamentalist Christians? Jews and fundamentalist Christians generally applaud American support of Israel. How do most Muslims feel about that? Jews and nonCatholic Christians until very recently have railed against parochial school aid; Catholics, of course, saw either Protestarian or secular humanism endorsed in public schools. Everyone but Catholics sued Ronald Reagan for his diplomatic recognition of the Vatican. And so on.

Bradley, supra note 55, at 732-33 (footnotes omitted).

257 The Supreme Court invalidated such a statute in Edwards v. Aguillard, 482 U.S. 578 (1987). 
likely would be offended by the teaching of what they regard as fundamentalist religion masquerading as science. Conversely, in a community composed largelly of religious conservatives, a "BalancedTreatment" statute would have the opposite effect: it may alleviate the considerable alienation generated by the exclusive teaching of evolution. ${ }^{258}$

Just as the relative offensiveness of particular messages for different groups might vary from community to community, it might also change over time. The scholarly treatment of publicly sponsored nativity scenes illustrates this possibility. In 1964, Professor Wilber Katz suggested that such displays were in principle unconstitutional but might be excused under a de minimis rationale. "If this means that our neutrality is a bit more neutral toward some than toward others," Katz observed, "a sense of humor should enable all of us to accept the situation .... ${ }^{n 259}$ By contrast, two decades later when the Court approved a nativity display in Lynch $v$. Donnelly, ${ }^{260}$ legal scholars were incensed. ${ }^{261}$ Leo Pfeffer went so far as to compare Lynch to the Dred Scott decision. ${ }^{262}$

These drastically different reactions were no doubt influenced in part by expectations arising from two decades of evolution in constitutional doctrine. This observation reflects a further difficulty in embodying an effective nonalienation policy in constitutional law: even if an adopted constitutional principle or doctrine were initially accurate in estimating the balance of alienation, the doctrine itself would likely alter the cultural dynamic in which that balance is

${ }^{258}$ Cf. Conkle, supra note 213 , at 1174 n.238 (noting that " $[\mathrm{t}]$ he teaching of evolution in the public schools ... deeply offends the religious beliefs of some").

259 WILBER G. KATZ, RELIGION AND AMERICAN CONSTITUTIONS 23-24 (1964).

260465 U.S. 668 (1984).

261 See Daan Braveman, The Establishment Clause and the Course of Religious Neutrality, 45 MD. L. REv. 352, 353 (1986) (Lynch was "devastating to first amendment doctrine"); Janet L. Dolgin, Religious Symbols and the Establishment of a National 'Religion,' 39 MERCER L. REv. 495, 502 (1988) (Lynch is comparable to Plessy $v$. Ferguson); Norman Dorsen, The United States Supreme Court: Trends and Prospects, 21 HARV. C.R.-C.L. L. REV. 1, 22 (1986) (Lynch "marked the greatest incursion to date on the separation of church and state"); Philip B. Kurland, The Religion Clauses and the Burger Court, 34 CATH. U. L. REV. 1, 12-13 (1984) (Lynch was "disingenuous" and "sleazy"); Douglas Laycock, Equal Access and Moments of Silence: The Equal Status of Religious Speech by Private Speakers, 81 Nw. U. L. REv. 1, 8 (1986) (Lynch was "wholly unprincipled and indefensible"); William Van Alstyne, Trends in the Supreme Court: Mr. Jefferson's Crumbling Wall-A Comment on Lynch v. Donnelly, 1984 DukE L.J. 770, 781 (Lynch showed "a paradigmatic disregard of the establishment clause in virtually every dimension of its concerns").

262 See PFEFFER, supra note 244 , at 124. 
grounded. Indeed, a doctrine purporting to forbid all governmental endorsement or disapproval of religion may give rise to a revolution of rising expectations, so that people become more sensitive to, and alienated by, what they formerly took for granted. ${ }^{263}$

Proliferating litigation in recent years over public religious symbols is perhaps an instance of this type of revolution, ${ }^{264}$ and there is no reason to assume the escalation is finished. Scholars have suggested, plausibly enough, that the "no endorsement" interpretation of religious freedom ought logically to invalidate numerous practices that the Supreme Court has not been forced to rule upon, including, for example, the names of cities like Corpus Christi and Los Angeles. ${ }^{265}$ It would hardly be surprising if these suggestions lead to further litigation and, inevitably, to further disappointment, frustration, and alienation on the part of one group or another.

Faced with this complexity, an advocate of the nonalienation rationale might be tempted to simplify the problem by focusing on one side of the alienation balance while ignoring the other. In this way, she might create the appearance of a necessary or uniform relationship-a relationship not closely dependent on cultural context-between political inclusiveness and a version of religious freedom. In essence, the Supreme Court has done this when applying its "no endorsement" interpretation of the Establishment Clause. ${ }^{266}$ Its decisions exhibit a very simple logic: religious

${ }^{263}$ Cf. Phillip E. Johnson, Concepts and Compromise in First Amendment Religious Doctrine, 72 CAL. L. REV. 817, 831 (1984) ("[B]y encouraging persons who are easily offended by religious symbolism to believe that the courts stand open to remedy their complaints, the courts foster divisive conflicts over religion.").

264 William Marshall, a supporter of the "no endorsement" interpretation, laments this pattern of escalation (although it does not lead him to doubt the wisdom of the "no endorsement" test):

An unfortunate pattern of litigation has engulfed the religion clause debate.

Divergent and often opposing groups seem intent on prohibiting what they deem offensive and have selected the religion clauses as their weapon of choice. Lawsuits attacking "humanist" textbooks, Christmas carols, football game invocations, graduation convocations, nativity scenes and the National Endowment for the Arts are just a few of the lawsuits that have been brought by credible organizations.

Marshall, supra note 212, at 375-76.

${ }^{265}$ See Laycock, supra note 261, at 8; Feigenson, supra note 152, at 98 n.210. Feigenson also argues that the display of religious art in public galleries raises major constitutional issues. See id. at 109-10.

${ }^{266}$ Although the Justices have acknowledged that context is important in determining whether a symbol sends a religious message, see County of Allegheny v. ACLU, 492 U.S. 573, 629 (1989) (O'Connor, J., concurring), the Court automatically 
symbols or messages emanating from government alienate some citizens; therefore, eliminating such symbols and messages will reduce alienation. The Court simply takes no account of the other side of the balance-the alienation that many persons feel toward a government they perceive as indifferent or hostile to religion, and that is likely to be aggravated by the results of the "no endorsement" version of religious freedom. ${ }^{267}$ This one-sided approach makes it impossible for the Court to assess whether its decisions do anything to reduce overall alienation, just as it would be impossible for a business to determine whether it made a profit if its accountants reported only gross revenues while refusing to acknowledge expenses.

Commentators who support the Court's general approach in this area are often more astute, or at least more candid, in recognizing its limitations. Although they acknowledge that any governmental action is likely to produce alienation in some citizens while reducing alienation in others, these scholars, nonetheless, favor a constitutional interpretation requiring government to act in the way that will minimize political alienation. ${ }^{268}$ Unfortunately, these scholars offer no practical way to measure net alienation. They may propose simple heuristic formulas, but these formulas are so vague and imprecise as to be almost useless.

For example, Daniel Conkle advocates an approach that would invalidate governmental messages disapproving of the religious beliefs of "outsiders," but would not be "overly concerned" with messages that offend the religious beliefs of "insiders." ${ }^{269}$ However, even assuming this test would produce net gains in nonalienation if it could be accurately applied, ${ }^{270}$ how is a court to decide

invalidates the challenged law or symbol once such a message is detected. The Court makes no effort to ascertain whether compelled elimination of the symbol will produce more alienation than the symbol itself produces.

${ }^{267}$ For a discussion of the problem of alienating religious citizens, see Gedicks, supra note 90 , at $432-39$.

${ }^{268}$ See, e.g., Conkle, supra note 213, at 1177-79 (adopting the norm of minimizing political alienation); Feigenson, supra note 152, at 82 n.143, 112 (advocating a requirement that government follow the "least alienating" alternative).

269 See Conkle, supra note 213, at 1177-79.

270 Although Conkle believes that messages offensive to "insiders" will produce less overall alienation, there appears to be no a priori reason to assume this is true. Indeed, on the assumption that in a majoritarian system there are likely to be more "insiders" than "outsiders," one might suppose just the opposite to be the case. Messages hostile to "insiders" should usually produce more overall alienation, if only because there are more "insiders" who will take offense. The earlier hypothetical about Baal-worshippers and Diana-worshippers reflects such a scenario. Given the 
who counts as an "insider" and who qualifies as an "outsider"? Conkle offers little guidance except to suggest that "insiders" are "those who are part of America's religious mainstream" and that "outsiders" include "individuals who hold minority religious or irreligious views. ${ }^{271}$ But these categories are so elastic and manipulable as to be almost useless. If one frames a category broadly-"Christian," for example, or "theist"-then nearly all American citizens will be "insiders." If one defines categories more specifically-by denomination, for instance-then everyone will be part of a religious minority. What about fundamentalist Christians, for example? They clearly see themselyes as "outsiders," 272 but because they are "Christians," they may also be regarded as "insiders." 273 It is ironic, moreover, that the effort to classify different groups of believers and nonbelievers as "insiders" and "outsiders" for constitutional purposes would seem to ratify and, if it were systematically implemented, even codify the very sense of first-class and second-class status the nonalienation rationale is ostensibly seeking to overcome.

If scholars amenable to the "no endorsement" test cannot present workable methods for measuring net alienation, that failure is hardly surprising. The task of measuring alienation is a formidable one; in view of the shifting and closely contextual nature of the problem, it is unlikely that any general rule of thumb will perform the task with even approximate accuracy. ${ }^{274}$ In the end, there-

difficulty in the real world of categorizing citizens as "insiders" or "outsiders," however, any prediction in this regard must remain a matter of pure speculation.

271 Conkle, supra note 213 , at 1178.

272 See MOORE, supra note 131, at 155-56 (describing the "perception of aloneness among evangelical Protestants"); $i d$. at 165 (noting " $[t]$ he outsider consciousness that [has] developed among average American Protestants"). Since 27 to 40 million Americans regard themselves as Fundamentalists or evangelicals, see $i d$. at 167, the alienation felt by this group can hardly be dismissed as negligible.

${ }^{273}$ Cf. Joel F. Carpenter, From Fundamentalism to the New Evangelical Coalition, in EVANGELICALISM AND MODERN AMERICA 3, 9 (George Marsden ed., 1984) (explaining how in different senses Fundamentalists have regarded themselves as both "insiders" and "outsiders").

274 Indeed, the very concept of "alienation," or symbolic exclusion, is difficult to grasp. What exactly is "alienation?" How, if at all, does "alienation" differ from the "anger," "annoyance," "frustration," or "disappointment" that every person who finds himself in a political minority is likely to feel? "Alienation" might refer to nothing more than an awareness by an individual that she belongs to a religious minority, accompanied by the realization that on some issues she is unlikely to prevail in the political process. Cf. Tushnet, supra note 140, at 712 (" $[\mathrm{N}]$ onadherents who believe that they are excluded from the political community are merely expressing the disappointment felt by everyone who has lost a fair fight in the arena of politics."). 
fore, the recommendation that government follow the "least alienating alternative" is akin to prescriptions urging government to "promote the general welfare" or to do what is best for the most citizens. Such counsels may be sensible enough, but they cannot be usefully embodied in uniform rules to be expounded by courts and implemented in an across-the-board fashion. ${ }^{275}$ Thus, the nonalienation rationale, even if one accepts the value or good it invokes, does not persuasively support a viable constitutional doctrine of religious freedom.

\section{G. A Categorical Assessment}

The foregoing analysis indicates that the common nonreligious rationales for religious freedom are vulnerable to serious objections. Typically these rationales either fail to identify anything distinctive about religion that warrants special constitutional treatment, or else they resort to claims that are controversial and even implausible in attempting to find something distinctive about religion. In addition, these rationales, even if accepted as plausible, may still be non sequiturs in that they fail to explain why religion deserves constitutional freedom from governmental restrictions or regulations.

Upon reflection, the shortcomings of the nonreligious rationales are hardly surprising. As discussed above, special constitutional protection for religion rests on the assumption that religion is in some important sense different from the general run of human interests and activities. The fundamental problem is to vindicate that assumption: how is religion different? From a religious perspective, the question is not difficult to answer. Religion is distinctive in its concern for spiritual goods, such as salvation of the soul, and in its deference to the claims of divine or transcendent authority. ${ }^{276}$ Nonreligious activities, pursuits, or disciplines do not purport to embrace the same concerns or the same deference to transcendent authority. From this perspective religion is not

That awareness may be uncomfortable, but is it a phenomenon for which constitutional law can provide an efficacious remedy? Constitutional doctrine that stifles the message will not likely alter the reality or a minority's experience of that reality.

${ }^{275}$ Cf. George W. Dent, Jr., Religious Children, Secular Schools, 61 S. CAL. L. REV. 863, 921-22 (1988) (arguing that whether removal of religiously offensive material from school curricula will reduce strife presents a question "that courts are illequipped to handlen and that is better left to local school boards).

${ }^{276}$ See Ingber, supra note 5 , at $285-87$. 
merely different from other human interests and activities, but is wholly incommensurable with them.

If one is precluded from adopting a religious perspective, however, the question of religion's distinctiveness becomes much more difficult. The nonreligious rationales attempt to resolve the issue by employing a dual strategy. They first focus upon the "secular" or "temporal" dimensions of religion, thus placing religion on a common plane or scale with other human interests and concerns. Having made religion commensurable with nonreligion, the rationales then attempt to differentiate religion by arguing that it occupies a unique place on the common plane or has a different order of value on the common scale. For example, religious faith may be regarded as a set of beliefs or as a psychological condition, like other beliefs or psychological conditions, but distinguishable as a peculiarly fervent or unyielding set of beliefs or a uniquely intense psychological condition. This type of assumption underlies the notion that religion is a distinctively potent source of civil strife or a singularly essential element in personal identity. ${ }^{277}$

In attempting simultaneously to assimilate and to differentiate religion, this dual strategy creates an internal tension that works to nullify the force of the nonreligious rationales. The problem is not that it is inevitably wrong to look at religion's secular or temporal dimensions, or to put religion on a common plane with other human activities and interests. Religion has its temporal dimensions-that is why it is a proper subject of study for historians, psychologists, and sociologists. However, religion's truly distinctive qualities inhere, not surprisingly, in its religious or spiritual dimensions. If one looks only at religion's temporal or secular aspects, these distinctive qualities become blurred. And if one insists on making claims of distinctiveness for religion while considering only its temporal dimension, the claims are likely to be implausible;

\section{Daniel Conkle argues:}

[R]eligious beliefs are strong, but at the same time fragile. They are strong because they are deeply embedded in the person's self. They are fragile for essentially the same reason. Although a person can ignore-brush offcertain types of insults, he cannot easily ignore a challenge to his selfidentity. In most cases, challenges of this sort will not change a person's religious beliefs, given the strength and resilience of such beliefs. But the challenges are likely to cause harm; they may amount to an assault on the person's most fundamental sense of being, inflicting a type of psychological injury, a form of mental anguish.

Conkle, supra note 213 , at 1165 . 
moreover, they will probably implicitly misrepresent the nature of religious faith.

These difficulties are evident in the claims of nonreligious rationales that religion is a special source of personal identity, moral character, or civil strife. There is a sense in which these contentions are true, or at least ought to be true, but it is not a strictly empirical sense; and since the nonreligious rationales offer them as empirical contentions, those rationales will inevitably seem suspect. The problem can be illustrated by an examination of what may be called the centrality contention-the contention that religion is the most central element in personal identity. ${ }^{278}$ This contention is basic to the personal autonomy rationale, and it is implicit in other common rationales. Arguments that religious beliefs are a uniquely powerful contributor to civic virtue, civil strife, or citizen alienation, all appear to assume that persons regard their religious commitments as more central and vital than other kinds of beliefs or interests. But is the centrality contention true?

Prior discussion has already raised this question; further difficulties will now be noted. From a religious perspective, the centrality contention may be true-but in a complex, elusive sense. In the first place, the contention may state a theological truth. Although different religious traditions would describe the matter in different terms, one familiar position asserts that the most crucial issue for every person-and an issue that is in an important way defining or constitutive of who and what a person is-concerns the principal object of a person's love. For Augustine, humanity was divided between those who love God and those who love primarily themselves. The two great cities, the City of God and the City of Man, are constituted by these two different kinds of love. ${ }^{279}$ This position might be understood to mean that a person's orientation toward a fundamentally religious issue is central to or even constitutive of personal identity.

But the centrality contention is true, in this view, only if it is understood and accepted as a theological assertion rather than as a statement about empirical psychology. The "two cities" position

278 See supra note 213.

279 See, e.g., AuguSTINE, The CrTY of God 14.13 (Gerald G. Walsh et al. trans., 1958) ("The one City began with the love of God; the other had its beginnings in the love of self."); see also id. at 14.28 ("What we see, then, is that two societies have issued from two kinds of love. Worldly society has flowered from a selfish love which dared to despise even God, whereas the communion of saints is rooted in a love of God that is ready to trample on self."). 
does not generate a prediction that most human beings as a matter of conscious belief or behavior hold religious faith to be the most essential part of their personal identity. On the basis of her theology, the believer or theologian may see a lack of faith or an absence of the love of God as the central distinguishing feature of the citizens of the worldly city; but it does not follow, and indeed it is wholly unlikely, that these individuals would define themselves in this way. Moreover, the dominant characteristics of any actual temporal society will be those of the City of Man, not the City of God; Augustine had no illusions on this point. ${ }^{280}$ Hence, if the theological assertion about the centrality of religion is recast as an empirical psychological proposition, it is likely to prove false.

Even for self-conscious religious believers, moreover, the contention that religion is central to personal identity should be understood as an aspirational statement. Christians are in principle committed to the precept that they must love God with all of their heart, soul, mind, and strength. ${ }^{281}$ This precept might again suggest that a religious faith is at the core of the Christian's personal identity. But this proposition cannot be taken as a simple factual assertion. Virtually every Christian falls far short of actually realizing the kind of love his faith prescribes, as the most devout are the first to admit. ${ }^{282}$ This deficiency does not prove that Christians are insincere-although, of course, they may be-but rather that Christianity, like other religious faiths, entails an internal conflict or struggle, and that the Christian's professions of belief often express aspirations, not accomplished facts. ${ }^{283}$

Even this statement oversimplifies the matter, however, because even when taken in an aspirational sense, statements of religious faith may not express the objectives toward which believers, in an empirical sense, do aspire, but rather the objectives toward which they believe they should aspire. ${ }^{284}$ In this way, even aspirational

${ }^{280}$ See id. at 18.1 (" [A]s far as human history goes, the [City of God] lives like an alien inside the [City of Man]."); $i d$. at 18.51 ("So it falls out that in this world, in evil days like these, the Church walks onward like a wayfarer stricken by the world's hostility .... It was never any different .... So it shall be until this world is no more.").

281 See Mark 12:29-30.

282 See Thomas Á Kempis, The IMTTATION OF CHRIST 38-39, 87, 122-24, 176-78 (Aloysius Croft \& Harry F. Bolton trans., 1962).

${ }^{283}$ Cf. Greenawalt, supra note 137, at 1025 ("Not everyone who has religious beliefs accords them the paramountcy in their lives that the beliefs call for. ${ }^{n}$ ).

284 This complex mindset is expressed in Augustine's prayer, offered in the early stages of his conversion: "Grant me chastity and continency, but not yet." ST. 
statements have a theological content: the believer is struggling to make her actual aspirations consistent with her religious beliefs. ${ }^{285}$ But the matter is still more complex because the religious struggle occurs within the realm of belief itself. This internal conflict is expressed in the paradoxical plea: "Lord, I believe; help thou mine unbelief." ${ }^{286}$ Hence, even statements about what Christians believe are misleading, and very likely false, if they are understood in a merely factual or static sense.

In sum, the propositions upon which the nonreligious rationales rely-propositions about the special nature and consequences of religion-might be true if understood in a theological sense, or in an aspirational sense with a theological component. But the prohibitory interpretation excludes theological claims; it requires these propositions to be taken in an empirical sense. And when understood as simple empirical assertions their status is quite dubious. At some historical moments, in some societies, they may be roughly correct. ${ }^{287}$ At most times and in most places, however, they are probably false. Indeed, the recurring biblical depictions of history as God's struggle with his people-a struggle that in the short-term, empirical sense God most often loses ${ }^{288}$-suggest that these propositions, understood empirically, will usually be false. Human beings typically will not make faith in God the center of their lives.

Augustine, The Confessions of St. Augustine, Bishop of Hippo 135 (J. G. Pilkington trans., 1927).

${ }^{285}$ Harvey Cox observes that "ultimately the most enduring tension between the secular and the spiritual runs straight through the soul of the individual." Harvey Cox, Citizens and Believers: Always Strangers?, in TRANSFORMING FAITH, supra note 83, at 53-54.

286 Mark 9:24.

${ }^{287}$ Usually, however, the contention that at a particular period people cared so deeply about religion that they were willing to, for example, resort to civil war over it is, at best, a vast oversimplification. For instance, depictions of the English civil war as a religious controversy sparked by perceived Papist practices which set Puritans, like Milton and Cromwell, against the monarchy, as represented by the Archbishop Laud, fail to take into account the variety of political, social, and economic factors that also influenced the conflict. For an overview of the various historical interpretations of the English civil war, most of which have emphasized secular rather than religious explanations, see J.G.A. Pocock, Introduction, in THREE BRTISH REvOLUTIONS: 1641, 1688, 1776, at 3-12 (J.G.A. Pocock ed., 1980).

${ }^{288}$ This depiction is presented in the Old Testament in, for example, the books of Deuteronomy, Isaiah, and Jeremiah. A similar view is expressed in the New Testament in Jesus' lament: "O Jerusalem, Jerusalem, thou that killest the prophets, and stonest them which are sent unto thee, how often would I have gathered thy children together, even as a hen gathereth her chickens under her wings, and ye would not!" Matthew 23:37. 
The nonreligious rationales thus offer contentions about the special character of religion in the sense in which those contentions are most questionable. For that reason, these rationales provide an infirm foundation upon which to build an enduring constitutional commitment to religious freedom.

\section{H. Commitment Without Reasons?}

It would be too much to say that the nonreligious rationales have no persuasive force at all. Indeed, these rationales are regularly invoked to justify religious freedom. ${ }^{289}$ In view of their serious defects, however, one must wonder whether this is an instance in which the conclusion gives force to the arguments, rather than vice versa. We still have a textual and historical commitment to religious freedom, and it is natural to assume there must be some justification for that commitment. Even though the nonreligious rationales are frail, one might conclude that if they are the only ones available they will just have to do.

Rather than force a conclusion to justify implausible premises, however, it would seem more sensible to take the conclusion as a given and give up the effort to supply premises. This observation might suggest that our inability to articulate any powerful and admissible justification for constitutional religious freedom is merely an academic problem. Perhaps we do not need any currently plausible justification to support the commitment to religious liberty. The fact is that we have made that commitment; it is written for anyone to see in the First Amendment of the Constitution. Nor does there appear to be a movement to repeal the religion clauses. So why does it matter if we cannot articulate any compelling rationale to justify that commitment?

One response is that without a plausible rationale for the commitment to religious liberty we cannot understand what that commitment entails. It is commonplace that legal enactments should be interpreted to effectuate their purposes. But a law's "purpose" arises out of, and is a projection of, its justification. Therefore, if we cannot articulate a convincing justification for the commitment to religious freedom then we cannot know its purpose, and we are accordingly paralyzed in our efforts to interpret the commitment.

${ }^{289}$ For a general discussion of their use in Supreme Court opinions, see Smith, supra note 15 . 
In addition, it is unrealistic to expect a commitment to retain its vitality merely because it is written into the Constitution. In a certain society or legal culture-the kind in which the highest recommendation of a law is that it has existed "from time immemorial ${ }^{290}$-the fact that a commitment to religious liberty is expressed in the Constitution might be sufficient. But clearly we do not live in that kind of culture; the pragmatic concern for doing what makes sense now is too strong. ${ }^{291}$ This aspect of our culture is expressed in Holmes's oft-quoted pronouncement: "It is revolting to have no better reason for a rule of law than that so it was laid down in the time of Henry IV. It is still more revolting if the grounds upon which it was laid down have vanished long since, and the rule simply persists from blind imitation of the past." ${ }^{292}$ Perhaps the most determined current proponent in the legal academy of a Burkean respect for the past concedes that this attitude has been defunct for generations and that the position is not only unpopular but almost incomprehensible today. ${ }^{293}$

Our experience with other constitutional provisions supports this assessment. Constitutional history chronicles the rise and decline of various constitutional provisions as they came to be seen as having or lacking a significant, timely rationale. In 1927, speaking for the Supreme Court, Holmes expressed the marginal status of the Equal Protection Clause by describing it as the "last resort of constitutional arguments. ${ }^{294}$ Today, with the increased concern for equality which has been evident at least since Brown $v$. Board of Education, ${ }^{295}$ that clause has assumed central significance in constitutional adjudication. By contrast, the clause forbidding impairment of contracts, once a prominent feature in the constitutional landscape, has become virtually invisible. ${ }^{296}$ Its decline

290 This was, apparently, the mindset of the common law in its classical period. For a helpful discussion, see GERALD J. POSTEMA, BENTHAM AND THE COMMON LAW TRADITION 4-29 (1986).

291 For an indication of the pervasive appeal of legal pragmatism, see Symposium on the Renaissance of Pragmatism in American Legal Thought, 63 S. CAL. L. REV. 1569 (1990).

292 Oliver W. Holmes, The Path of the Law, 10 HaRv. L. REv. 457, 469 (1897).

293 See Anthony T. Kronman, Precedent and Tradition, 99 YALE L.J. 1029, 1043-47 (1990).

${ }^{294}$ Buck v. Bell, 274 U.S. 200, 208 (1927).

295347 U.S. 483 (1954).

${ }^{296}$ See JOHN E. NOWAK ET AL., CONSTITUTIONAL LAW 372 (3d ed. 1986) ("[U]ntil the late nineteenth century the contract clause was the principal provision the Court used to void legislation that infringed on private property rights. Within the last 100 years, however, the Court rarely has relied on the clause as a reason to invalidate state 
cannot be attributed to the absence of potential modern applications (in the way, for instance, that we might account for the dormant condition of the Third Amendment's prohibition on the quartering of soldiers). Rather, the assumptions on which the Contracts Clause appears to be based-assumptions grounded in notions of the minimalist state-are incompatible with the nature of modern government, ${ }^{297}$ and so the clause has been quietly retired from active duty. It is not fanciful to think that unless a powerful, timely rationale for affording special constitutional status to religion can be articulated, the religious freedom clauses might well follow a similar course.

\section{THE DETERIORATION OF CONSTITUTIONAL RELIGIOUS FREEDOM}

The constitutional commitment to religious freedom arose from, and can be adequately justified only by reference to, a religious rationale that is no longer admissible in legal and academic discourse. Proposed secular replacements for this justification are vulnerable. If the nonreligious rationales sometimes seem to carry the day, that may be because they lead to a conclusion that we instinctively support-likely a case of the conclusion earning favor for the arguments, not vice versa.

Such a situation is plainly unstable; it is a condition that invites the collapse of the commitment to religious freedom. And, indeed, signs of serious deterioration are apparent. These "signs of the times" will be discussed under two headings: incoherence in constitutional reasoning and withdrawal of constitutional protection for religious freedom.

\section{A. Incoherence: County of Allegheny}

If a legal culture is confronted with a constitutional commitment it instinctively respects but cannot adequately understand or justify, one would expect to find considerable confusion in the interpretation and application of that commitment. Unsurprisingly, therefore, judicial decisions expounding and enforcing the Constitution's

legislation which retroactively affected contractual rights ....").

297 See TRIBE, supra note 14, § 8-6, at 578-81 (describing changes in thinking about the role of government that undermined the idea of contractual liberty as a foundation for constitutional thought); see also BRUCE A. ACRERMAN, RECONSTRUCTING AMERICAN LAW 6-22 (1984) (describing how the rise of the "activist state" undermined the sanctity of older common law notions of contract and property). 
religion clauses are characterized by massive incoherence. The disarray is by now notorious. With respect to the Court's Establishment Clause decisions, Charles Taylor offers the restrained observation that "there does not seem to be any defensible intellectual principle underlying them. ${ }^{298}$ Philip Kurland puts the point more bluntly: the Supreme Court's establishment decisions seem "derived from Alice's Adventures in Wonderland."299 John Mansfield dismisses the Court's religion clause opinions as "the incantation of verbal formulae devoid of explanatory value." $\$$

The celebrated conflict that, at least until recently, often pitted the Establishment Clause against the Free Exercise Clause has often been cited as evidence of the unhappy condition of current religion clause jurisprudence. ${ }^{301}$ Another favorite method of demonstrating the prevailing confusion has been to recite a list of paired but apparently incompatible decisions purporting to interpret the religion clauses. ${ }^{302}$ As the incoherence of religion clause doctrine has matured, however, it is no longer necessary to compare different doctrines or different lines of cases; the confusion is manifest within single decisions.

In this respect, County of Allegheny v. $A C L U^{303}$ is exemplary. The case represents the culmination of modern Establishment Clause interpretation in two respects. First, although the Supreme Court had referred to the "no endorsement" test in earlier decisions, ${ }^{304}$ in County of Allegheny a majority of Justices unequivocally

298 Taylor, supra note 202, at 111.

299 Kurland, supra note 261 , at 10 . For similarly caustic criticisms, see LEONARD W. Levy, The ESTABlishment ClaAuse: RELigion AND THE FIRST AMENDMENT 128 (1986) ("[Establishment Clause decisions] make distinctions that would glaze the minds of medieval scholastics."); Gedicks \& Hendrix, supra note 86, at $1611 \mathrm{n.146}$ (noting the Court has displayed "spectacular incoherence in articulating the constitutional law of religion"); Rex E. Lee, The Religion Clauses: Problems and Prospects, 1986 B.Y.U. L. REV. 337, 338 (1986) ("A decent argument can be made that the net contribution of the Court's precedents toward a cohesive body of law . . . has been zero. Indeed, some would say that it has been less than zero . . . "); Mark V. Tushnet, Reflections on the Role of Purpose in the Jurisprudence of the Religion Clauses, 27 WM. \& MARY L. REV. 997, 997 (1986) (" [V]irtually everyone who has thought about the religion clauses, finds the Supreme Court's treatment of religion clause issues unsatisfactory.").

${ }^{300} \mathrm{John}$ H. Mansfield, The Religion Clauses of the First Amendment and the Philosophy of the Constitution, 72 CAL. L. REV. 847, 848 (1984).

${ }^{301}$ See, e.g., Choper, supra note 187, at $947-48$.

302 See LEVY, supra note 299, at 128-29, 162-63; Kurland, supra note 261, at 10-11;

Paulsen, supra note 245, at 316; Tushnet, supra note 140 , at 705.

303492 U.S. 573 (1989).

${ }^{304}$ See, e.g., Witters v. Washington Dep't of Servs. for the Blind, 474 U.S. 481, 488- 
embraced that doctrine ${ }^{305}$-a doctrine which, as I have argued in this Article, makes clear the implications of the prohibitory interpretation of religious freedom. Second, perhaps more than any other single decision, County of Allegheny reveals the multidimensional confusion inherent in the prevailing understanding of religious freedom. The case reflects confusion in the application of the doctrine to specific facts, in the connection (or lack of connection) between the doctrine and its ostensible rationale, and most fundamentally in the latent ambivalence of the prevailing position with respect to religious freedom itself.

In County of Allegheny the Court applied the "no endorsement" test to invalidate a municipal display of a Christmas creche while approving the display of a Jewish menorah. While conceding that the "no endorsement" test is "highly context specific" and requires "often difficult line drawing," Justice O'Connor insisted that the test is "capable of consistent application." ${ }^{306}$ But it is hard to imagine a more compelling refutation of that claim than the one provided in the case itself by the wildly divergent opinions of the Justices who accepted and attempted to apply the test.

A central question in the case was whether a public holiday season display featuring an eighteen foot menorah alongside a fortyfive foot Christmas tree sent a message endorsing religion. To Justice Blackmun, the Christmas tree itself was a purely secular symbol. Moreover, its greater size had the effect of neutralizing the potential religious message of the menorah. ${ }^{307}$ Taken as a whole, therefore, the display communicated "not a simultaneous endorsement of both the Christian and Jewish faiths, but instead, a secular celebration of Christmas coupled with an acknowledgment of Chanukah as a contemporaneous alternative tradition. ${ }^{\text {308 }}$

Justice O'Connor saw things differently. While accepting Justice Blackmun's characterization of the Christmas tree as a "secular" symbol, she disagreed with Blackmun's perception that the tree somehow neutralized the religious symbolism of the menorah. ${ }^{309}$ Nonetheless, she concluded that the display did not endorse Judaism, or religion generally, but rather sent a message celebrating

89 (1986); Wallace v. Jaffree, 472 U.S. $38,56 \&$ n.42 (1985).

${ }^{805}$ See County of Allegheny, 492 U.S. at 592.

${ }^{306} \mathrm{Id}$. at 631-32 (O'Connor, J., concurring).

807 See id. at 616-18.

${ }^{308}$ Id. at $617-18$.

${ }^{309}$ See id. at 632-34 (O'Connor, J., concurring). 
"pluralism and freedom of belief." was permissibly secular.

The display generated a different perception altogether for Justice Brennan. He insisted that Justices Blackmun and O'Connor went "badly astray" in regarding the Christmas tree as a secular symbol. ${ }^{311}$ Although Justice Brennan conceded that "the tree alone may be deemed predominantly secular," he declared that "it can hardly be so characterized when placed next to such a forthrightly religious symbol." ${ }^{\text {312 }}$ Moreover, Justice Blackmun had things exactly backwards in asserting that the Christmas tree's superior size neutralized the menorah's religious significance. The tree, Justice Brennan noted, was "rather conventionally sized." On the other hand, though much smaller than the tree in actual size, the menorah was large for a menorah, and thus was "far more eye catching." Furthermore, while the tree could be seen as conveying multiple messages, the menorah conveyed only a single, clearly religious message. As a result, the menorah transformed the tree into a religious symbol, not vice versa. ${ }^{313}$

Justice Brennan also rejected Justice O'Connor's view that the display was permissible because it celebrated "pluralism and freedom of belief." Even if the display in fact endorsed these values, he observed, it was religious pluralism and freedom of religious belief that were most obviously represented. ${ }^{814}$ Moreover, since not all religions believe in religious pluralism, a message endorsing such pluralism favors some religions over others, and thereby impermissibly offends religions that do not accept the value of pluralism. ${ }^{315}$ Justices Stevens and Marshall joined in Justice

${ }^{310} I d$. at 635 .

311 See id. at 641 (Brennan, J., concurring in part and dissenting in part).

312 Id.

313 See id. at 642.

${ }^{314}$ See id. at 640 ("[T] pluralism, and the "freedom of belief she emphasizes is freedom of religious belief."). Justice Brennan considered the possibility that Justice O'Connor might have perceived in the display a message of cultural pluralism, not of specifically religious pluralism. But if Justice O'Connor were approving the display based on this kind of perception, he argued, she ought equally to approve displays featuring "a menorah next to a giant firecracker" or "a Latin cross next to an Easter bunny." In each instance, Justice Brennan observed, "I do not sense that this display would pass muster under Justice O'Connor's view." Id. at 640 n.*. Since Justice O'Connor did not explicitly address Justice Brennan's hypotheticals, however, the constitutionality of menorah-firecracker and cross-bunny displays remains in doubt pending further illumination by the Court.

${ }^{815}$ See id. at 645 . 
Brennan's opinion, and Justice Stevens also wrote a separate opinion that largely agreed with Justice Brennan's analysis. ${ }^{316}$

This disarray plainly reveals the uncertainty and inconsistency that plague the application of current doctrine. ${ }^{317}$ The Justices were evidently able to perceive, or not to perceive, essentially any message they chose; and there is no rational method for determining whether what Justice Blackmun perceived was somehow more "correct" than what Justices O'Connor, Brennan, and Stevens sensed. ${ }^{318}$ But, the Court's confusion affected not only the application of doctrine to facts; it also infected the Court's attempt to relate the "no endorsement" doctrine to its stated rationale.

The ostensible purpose of the "no endorsement" test is to ensure that no citizens will be made to feel like "outsiders, or less than full members of the political community, " because of governmental endorsement or disapproval of religion. ${ }^{319}$ Yet it is virtually certain, as the differing perceptions of the Justices themselves suggest, that regardless of the outcome reached by the courts in this and similar controversies, some citizens will perceive the outcome as endorsing or disapproving of religion. ${ }^{320}$ Hence, as argued earlier, the "no endorsement" test is sure to aggravate alienation in some citizens. The Court attempted to deal with the problem by declaring the dispositive perception to be that of a "reasonable" observer. ${ }^{321}$ But that position does nothing to solve

${ }^{316}$ See id. at 646-55 (Stevens, J., concurring in part and dissenting in part).

${ }^{317}$ See Gey, supra note 140, at 119 (asserting that the endorsement test is "so malleable that it can mean anything"); of. Shahin Rezai, Note, County of Allegheny v. ACLU: Evolution of Chaos in Establishment Clause Analysis, 40 AM. U. L. REV. 503, 504 (1990) ("[T] he Supreme Court in County of Allegheny v. ACLU further confused the already chaotic jurisprudence relating to the state's involvement with religious symbols and practices.").

318 Consequently, even supporters of the "no endorsement" doctrine have criticized the decision for its lack of clarity. Neal Feigenson, an enthusiastic proponent of the Court's general approach, concedes that the "no endorsement" doctrine as applied by the Court has done nothing to enhance clarity or predictability in the law, see Feigenson, supra note 152, at 91-92, and he observes that County of Allegheny "did little to ameliorate the confusion in a concededly muddled area of constitutional law." Id. at 53.

${ }^{319}$ County of Allegheny, 492 U.S. at 627 (O'Connor, J., concurring); see also id. at 595.

${ }^{320}$ Cf. Mark V. Tushnet, Religion and Theories of Constitutional Interpretation, 33 LOY. L. REV. 221, 238 (1987) ("Lynch[, the 1984 nativity scene decision,] was like a slap in the face to many Jews, but surely a holding that a municipal creche was unconstitutional would have been just as much a slap in the face to a segment of the Christian community.").

${ }^{321}$ See County of Alllegheny, 492 U.S. at 630-31 (O'Connor, J., concurring). 
the problem. Instead, the Court's doctrine adds insult to injury by telling a losing party not only that she has lost, but that her perceptions of endorsement or disapproval have been disregarded because she is not a "reasonable" observer. ${ }^{322}$

Finally, and most fundamentally, County of Allegheny reflects the confusion that must inevitably arise when a constitutional commitment is interpreted in such a way that it negates its own reason for existence. The consequence of this difficulty is an unavoidable ambivalence toward religious liberty. Such ambivalence is discernible in Justice Brennan's remarkable suggestion that it was unconstitutional for Allegheny County, Pennsylvania, to send a message endorsing religious pluralism and freedom of religious belief. ${ }^{323}$ Upon first consideration, one may wonder whether Justice Brennan could have been serious about his suggestion. After all, by forbidding the establishment of any official religion, the Establishment Clause itself unequivocally favors religious pluralism. Carried to its logical conclusion, Justice Brennan's position would mean that the Establishment Clause itself is unconstitutional-on Establishment Clause grounds. Similarly, the Free Exercise Clause would seem to express concern for and approval of the freedom of religious belief. Is it therefore unconstitutional for government (or the Court) to invoke or express approval of the Free Exercise Clause?

As remarkable and apparently self-contradictory as it seems, however, Justice Brennan's position is in a different sense perfectly logical. Not all forms of freedom and pluralism are equally valued;

322 The conflict between the "no endorsement" doctrine and its own rationale is manifest in Justice Blackmun's treatment of the dissenting Justices. As noted, the controlling opinions by Justices Blackmun and O'Connor emphasized the need to avoid alienating any citizens or making them feel like outsiders because of their religious views. The opinions did not directly discuss how this policy should apply to the apparently substantial body of citizens who, on the basis of their own religious views, are offended and alienated by the systematic, judicially directed removal of traditional religious symbols from public life. However, a tame version of this view was suggested in Justice Kennedy's opinion, joined by Justices Scalia, White, and Rehnquist, which implied that the position taken by the majority might reflect a "latent hostility" or "callous indifference" toward religion. See id. at 657, 663-64 (Kennedy, J., concurring in part and dissenting in part). At least Blackmun interpreted the opinion as making such a charge, and he sharply rebuked Kennedy for expressing views "as offensive as they are absurd." Id. at 610. As noted, however, Kennedy's suggestions are no doubt representative, apart from their mildness, of the perceptions of large numbers of American citizens. And it is just possible that the best way to make these citizens feel like fully included members of the community is not to condemn their perceptions, which clearly reflect their own religious beliefs, as "offensive" and "absurd."

${ }^{323}$ See supra notes $314-15$ and accompanying text. 
hence, to celebrate religious pluralism and religious freedom does send a message suggesting a special concern for religion. And if religious freedom means that government must be neutral regarding religion, ${ }^{324}$ then the celebration of religious freedom (with the favorable message that such a celebration entails) is inconsistent with the meaning of religious freedom. Hence, Justice Brennan's position accurately reflects the logical course-and the self-canceling culmination-of the prevailing interpretation of religious freedom.

\section{B. Withdrawal of Protection: Employment Division, Department of Human Resources v. Smith}

A second consequence of the loss of a viable justification for the constitutional commitment to religious liberty is that courts may simply decide that the commitment has lost its vitality and should no longer be enforced. The incoherence accompanying judicial efforts to expound the meaning of that commitment might naturally reinforce this impulse: one obvious way to avoid the confusion surrounding religion clause jurisprudence is to retreat from the effort to construe or enforce the clauses at all. It is not surprising, therefore, that recent decisions reflect a tendency to reduce or withdraw protection for religious freedom.

This trend is discernible in a number of areas. The relaxation of protection against state intrusion into the affairs of religious institutions is one notable instance. ${ }^{325}$ Another is the minimalist interpretation the Court has given to Title VII's requirement that employers accommodate their employees' religious faiths. ${ }^{326}$ But perhaps the most dramatic example is the virtual abandonment of the Free Exercise Clause in the recent case of Employment Division, Department of Human Resources v. Smith. ${ }^{327}$ Just as County of

${ }^{324}$ See County of Allegheny, 492 U.S. at 644 (Brennan, J., concurring in part and dissenting in part) ("We have ... . interpreted [the Establishment] Clause to require neutrality, not just among religions, but between religion and nonreligion.").

325 For a valuable discussion which links the declining respect for church autonomy to the exclusion of religious concepts from constitutional discourse, see generally Gerard V. Bradley, Church Autonomy in the Constitutional Order: The End of Church and State?, 49 LA. L. REv. 1057 (1989). See also GovERNMENT INTERVENTION IN RELIGIOUS AFFAIRS, II (Dean M. Kelley ed., 1986); Smith, supra note 142, at 982-85.

${ }^{326}$ See Trans World Airlines, Inc. v. Hardison, 492 U.S. 63, 84 (1977) (ruling that employers are relieved from the statutory accommodation requirement on grounds of "undue hardship" if accommodation would entail "more than a de minimis cost"). For a critical discussion, see David E. Wheeler, Establishment Clause Neutrality and the Reasonable Accommodation Requirement, 4 HASTINGs CoNST. L.Q. 901 (1977).

327110 S. Ct. 1595 (1990). 
Allegheny represents a culmination of troubling developments in Establishment Glause jurisprudence, Smith reaches a low point in modern constitutional protection under the Free Exercise Clause.

The claimants in Smith were members of the Native American Church who were discharged from their jobs with a private drug rehabilitation organization because they used peyote for sacramental purposes. Oregon denied their applications for unemployment compensation, reasoning that because state law prohibits the use of peyote the claimants had been discharged for "misconduct," making them ineligible to receive unemployment benefits. ${ }^{328}$ The facts of the case were similar in significant respects to those of other cases in which the Court had upheld free exercise claims. In Sherbert $v$. Vermer, ${ }^{329}$ for example, the Court had ruled that South Carolina could not deny unemployment compensation to a SeventhDay Adventist who refused available employment because of her religious scruples against working on Saturday. And in Thomas v. Review Board, ${ }^{330}$ the Court had held that Indiana must provide unemployment compensation to a Jehovah's Witness who left his job after coming to believe that his work in a munitions plant was sinful. ${ }^{331}$ In reaching these results, the Court had indicated that if a state law burdens an individual's practice of her religion, the state should exempt that inclividual unless the state has an especially important interest in requiring compliance. ${ }^{332}$

Under this doctrine of free exercise exemptions, and on the strength of precedents such as Sherbert and Thomas, the Court could readily have ruled for the claimants in Smith. Conversely, if the Justices were disposed to deny relief, as they seem to have been, they might have ruled that Oregon's interest in controlling the use of drugs-an interest the state had embodied in a criminal statuteoverrode the claimants' free exercise rights, thus leaving free exercise doctrine undisturbed. ${ }^{333}$ The majority, however, chose

${ }^{328}$ See id. at 1597-98.

329374 U.S. 398 (1963).

330450 U.S. 707 (1981).

331 The Court reaffirmed this position in more recent unemployment compensation cases. See Frazee v. Illinois Dep't of Employment Sec., 489 U.S. 829 (1989); Hobbie v. Unemployment Appeals Comm'n, 480 U.S. 136 (1987).

392 For other recent cases asserting this balancing test, see Jimmy Swaggart Ministries v. Board of Equalization, 493 U.S. 378, $391-92$ (1990); Hernandez v. Commissioner, 490 U.S. 680, 699 (1989). For a useful overview and analysis of free exercise doctrine before Smith, see Ira C. Lupu, Where Rights Begin: The Problem of Burdens on the Free Exercise of Religion, 102 HARV. L. REV. 933, 933-66 (1989).

${ }^{833}$ Justice O'Connor took this position. See Smith, $110 \mathrm{~S}$. Ct. at 1606-15 
to adopt neither of these alternatives. Instead, it declared that so long as a law is general and neutral in its application, that law's interference with an individual's practice of his religion provides no constitutional ground for exempting that individual from compliance. ${ }^{334}$

Although abandoning the doctrine of free exercise exemptions, the Court indicated that a law which actually discriminates against religion, or which proscribes a practice because it is religious, would be unacceptable. ${ }^{335}$ However, laws that consciously discriminate against religion are uncommon, ${ }^{336}$ and in any event are probably invalid on other constitutional grounds. ${ }^{337}$ Consequently, Smith appears to leave the Free Exercise Clause without independent constitutional content and thus, for practical purposes, largely meaningless. ${ }^{338}$ Douglas Laycock comments caustically that " $[t]$ he free exercise of religion now means that churches cannot be taxed or regulated any more heavily than General Motors."

Critics have attacked the decision as a dramatic departure from modern doctrine, and on a verbal level they are right. The Court attempted to square its ruling with the pronouncements in earlier free exercise cases, but as commentators have convincingly shown,

(O'Connor, J., concurring).

${ }^{334}$ See $i d$. at 1600 .

395 See id. at 1599.

336 The Court's own examples suggest how far removed this non-discrimination constraint is from contemporary conflicts in this country. The Court suggested that it would be unconstitutional for a state to prohibit religious believers from "bowing down before a golden calf" or from making statues to be used for worship purposes. See id.

${ }^{337}$ Such discriminatory legislation would likely violate the Equal Protection Clause. See New Orleans v. Dukes, 427 U.S. 297, 303 (1976) (asserting that equal protection suspect classifications include "race, religion, and alienage"); $c f$. Larson v. Valente, 456 U.S. 228 (1982) (finding an equal protection component in the Establishment Clause). In addition, laws specifically discriminating against religion would often have a content-based impact upon expression, and thus might violate the Free Speech Clause. See Widmar v. Vincent, 454 U.S. 263 (1981) (invalidating on free speech grounds a university regulation preventing student religious groups from using university facilities for group meetings).

${ }^{338}$ Although it might be suggested that the Free Exercise Clause still protects religious beliefs, such freedom of belief is protected under the rubric of free speech in any case. See Abood v. Detroit Bd. of Educ., 431 U.S. 209, 234-35 (1977) (declaring that "at the heart of the First Amendment is the notion that the individual should be free to believe as he will").

${ }_{339}$ Douglas Laycock, Formal, Substantive, and Disaggregated Neutrality Toward Religion, 39 DEPAUL L. REv. 993, 1009 (1990); see also Milner S. Ball, The Unfree Exercise of Religion, 20 CAP. U. L. REV. 39, 49 (1991) (arguing that Smith is "desperately wrong and terribly damaging"). 
its arguments in this respect were patently untenable. ${ }^{340}$ As an exhibition of legal analysis, Justice Scalia's majority opinion in Smith is an intellectual disaster. Perhaps the most remarkable feature in a generally remarkable opinion is the majority's reliance on language from Minersville School District $v$. Gobitis ${ }^{341}$ to prove that religious objectors have never been excused from compliance with generally applicable laws because of their religious scruples. ${ }^{342}$ The majority seemed not to notice that Gobitis was overruled just three years later in the well-known case of West Virginia State Board of Education v. Barnette, ${ }^{343}$ and that in any event Gobitis was decided well before the elaboration of the doctrine of free exercise exemptions in cases such as Sherbert and Wisconsin v. Yoder. ${ }^{344}$ Michael McConnell notes that "[r]elying on Gobitis without mentioning Barnette is like relying on Plessy v. Ferguson without mentioning Brown v. Board of Education. ${ }^{\text {345 }}$

At a deeper level, however, Smith represents not a departure from, but rather the culmination of modern free exercise jurisprudence. Smith disavowed (without admitting it) much of what the recent decisions said, but it respected and followed what those decisions did. Since the 1972 decision in Yoder, when the Court ruled that Wisconsin could not compel Amish children to attend a formal school after the age of fourteen, the Court had consistently rejected virtually every claim for a free exercise exemption that it confronted. The only exception concerned unemployment compensation cases similar on their facts to Sherbert, which the Court decided (and may continue to decide where no criminal law is at issue) simply on the strength of that precedent. ${ }^{346}$ In other cases, the Court either rejected the religious claims with little

${ }^{340}$ See, e.g., James D. Gordon, III, Free Exercise on the Mountaintop, 79 CAL. L. REV. 91 (1991) (concluding that the Court in Smith "mistreated precedent [and] used shoddy reasoning"); Michael W. McConnell, Free Exercise Revisionism and the Smith Decision, 57 U. CHI. L. REV. 1109, 1114-27 (1990) (criticizing the Court for misreading the Free Exercise Clause, ignoring its historical context, and using precedent in a "troubling" fashion). Although defending the doctrinal revisionism of Smith, William Marshall concedes that "[ $t]$ he decision, as written, is neither persuasive nor wellcrafted. It exhibits only a shallow understanding of free exercise jurisprudence and its use of precedent borders on fiction." Marshall, supra note 215, at 308-09.

341310 U.S. 586 (1940).

${ }^{342}$ See Smith, 110 S. Ct. at 1600.

343319 U.S. 624 (1943).

344406 U.S. 205 (1972).

345 McConnell, supra note 340, at 1124 (citation omitted).

${ }^{346}$ See supra note 331. 
attempt to duplicate the careful balancing apparent in Yoder, ${ }^{347}$ or it declared balancing unnecessary for cases involving the military, ${ }^{348}$ prisons, ${ }^{349}$ or the management of federal property. ${ }^{350}$ Thus, any active judicial commitment on the part of the Court to protect the free exercise of religion was virtually defunct even before Smith officially announced the demise of the free exercise exemption doctrine. In this sense, Smith merely made explicit what was implicit in earlier rulings. ${ }^{351}$

Smith also made explicit what other recent cases only assumed by confronting and rejecting the religious justification for religious freedom. Cases claiming a religious exemption from general laws present the religious justification in perhaps its purest form. The believer asserts, in essence, that she should be excused from compliance with a particular law because of her prior or superior obligation to a higher authority. This assertion is virtually a paraphrase of the primary argument advanced in Madison's Memorial and Remonstrance. ${ }^{352}$ The claim to a religious exemption, in short, is in itself tantamount to an assertion of the religious justification. In Smith the Court considered and rejected that justificatory claim.

The majority's reason for rejecting the religious justification deserves attention. The opinion offered a prudential rationale: the recognition of free exercise exemptions would be "courting anarchy" by making every person's conscience a "law unto itself." B53 But this prudential argument cannot adequately explain the Court's position. In the first place, so long as free exercise

${ }^{347}$ See, e.g., Tony \& Susan Alamo Found. v. Secretary of Labor, 471 U.S. 290 (1985) (declining to recognize free exercise exemption to the Fair Labor Standards Act); United States v. Lee, 455 U.S. 252 (1982) (holding that conflict between religious belief and obligation to pay taxes affords no basis for resisting such taxes).

${ }^{348}$ See Goldman v. Weinberger, 475 U.S. 503 (1986).

${ }^{349}$ See O'Lone v. Estate of Shabbaz, 482 U.S. 342 (1987).

${ }^{350}$ See Lyng v. Northwest Indian Cemetery Protective Ass'n, 485 U.S. 439 (1988).

351 Writing shortly before the Smith decision, Mark Tushnet observed that "people are led to believe that there is a general doctrine of mandatory accommodation, a belief that the Court's decisions basically belie." Mark V. Tushnet, "Of Church and State and the Supreme Court": Kurland Revisited, 1989 SUP. CT. REV. 373, 379. Although criticizing Smith for abandoning the doctrine of free exercise exemptions, Michael McConnell acknowledges that even before Smith "the free exercise doctrine was more talk than substance." McConnell, supra note 340, at 1109 . He points out, however, that the doctrine was sometimes taken more seriously by state and lower federal courts. See id. at 1110.

${ }^{352}$ See supra notes $46-47$ and accompanying text.

${ }^{353}$ Smith, 110 S. Ct. at 1605, 1606. 
doctrine is subject to a balancing test-and everyone involved in the case assumed that it would be-the Court could adjust the balance to prevent religious claims from undermining the social order. Decades of experience with free exercise doctrine suggest that courts are more likely to err on the side of order than of anarchy.

Moreover, in an important sense the Court's prudential argument assumes the point at issue. If the religious justification is valid, if compelling the religious believer to comply with a general law really would offend a higher power, then the Court would be illadvised to reject the claim on the basis of purely prudential concerns. The prudential argument is the kind of rationale a court is likely to offer after it has already decided that the religious justification is unacceptable.

If the prudential argument does not adequately account for the Court's rejection of the claimants' religious rationale, then how should the Court's position be explained? One possibility is that the Justices who composed the majority considered the religious rationale and rejected it on its merits because they do not believe that any higher authority or higher law exists. This explanation seems implausible, however, particularly in the case of Justice Scalia, who authored the majority opinion. ${ }^{354}$ It is more likely that the Justices did not reject the religious justification because of any intrinsic substantive implausibility, but rather that they believed religious claims to be excluded from official consideration by the logic of the secular state, as expressed in the prohibitory interpretation of religious freedom.

Read closely, the language of the majority opinion provides at least tacit support for this explanation. As noted, the Court asserted that a doctrine of free exercise exemptions would make every believer's conscience "a law unto itself." 355 Initially, this assertion appears to be a willful mischaracterization of the believer's claim. In asking for a free exercise exemption the believer emphatically does not claim to be the source of law for himself; the whole point of the claim is that the believer is bound by a heteronomous obligation imposed by a higher authority. The "law unto itself" characterization, however, may be understood as the translation of this religious claim into a language in which no higher

354 See Barbara A. Perry, The Life and Death of the "Catholic Seat" on the United States Supreme Court, 6 J.L. \& POL. 55, 86 (1989) (suggesting that Scalia is heavily influenced by his Roman Catholic education).

355 Smith, 110 S. Ct. at 1606. 
authority can be acknowledged. If there is no higher authority-or at least none that the state is permitted to recognize-then regardless of how the claimant characterizes his belief, the source of the obligation invoked by the believer can only be the individual himself. Hence, the Court's very characterization of the free exercise claim reflects its assumption of a prohibitory interpretation that precludes recognition of religious beliefs as a ground for governmental or judicial decisions.

In sum, although earlier decisions tacitly dismissed the religious justification for religious freedom by not invoking it or by ruling against claims for free exercise exemptions, the dismissal became explicit in Smith. Smith also exhibits the consequences of that dismissal-the withdrawal of constitutional protection for the free exercise of religion.

\section{CONCLUSION}

This Article paints a bleak picture of current constitutional discourse in the area of religious freedom. In the tradition of happy endings, it ought now to explain the solution to these difficulties, or at least to suggest that the situation is not as dismal as it may seem. In that spirit, I will conclude with two more optimistic observations. A forewarning is in order: these observations give no cause or excuse for rejoicing; they seek only to elevate the tone of the Article from unmitigated to mitigated pessimism.

The first optimistic observation is that history may not be deterministic. Arnold Toynbee, chronicling what he often seemed to regard as the fatalistic flow of history through a series of regular, repetitive cycles, nonetheless insisted on the possibility of human freedom, and thus of escape from the usual cyclical pattern. ${ }^{356}$ In this Article I have argued that the deterioration of our constitutional commitment to religious freedom is the natural consequence of a fatal flaw-a paradoxical, self-canceling quality-within the prevailing modern understanding of what religious freedom means. But there is nothing necessary or logically inexorable about our modern understanding of religious freedom; coherent and defensible alternatives are available that do not produce the debilitating

956 See 9 ARNOLD J. TOYNBEE, A STUDY OF HistoRY 167-405 (1954). Toynbee ultimately offered a religious explanation for human freedom: humans can escape the deterministic Law of Nature by accepting the Law of Love, which is God's "perfect law of liberty." Id. at 395. 
consequences evident in constitutional discourse today. ${ }^{357}$ It is always possible that the Supreme Court and the constitutional community may abandon the prohibitory interpretation of religious freedom and place our constitutional commitment on firmer footing.

It is hard to be sanguine, however, about that prospect. Although freedom to alter the apparent course of history is a theoretical possibility, dominant ideas seem to gain a momentum that resists conscious changes of direction. Moreover, legal ideas become embedded in the broader workings of politics and culture, acquiring an additional mass that increases their inertia.

This inertia is observable in the law of religious freedom. At this juncture, one can plausibly view the modern jurisprudence of the religion clauses as a gradual unfolding of a few core ideas-the "wall" of separation, governmental neutrality, the secular stateexpressed in the first modern establishment case, Everson v. Board of Education. ${ }^{358}$ Everson purported to draw those ideas from history, but at least as early as 1965 it was clear that Everson was bad history, for which a thoughtful Harvard law professor convincingly and sharply rebuked the Court. ${ }^{359}$ "By superficial and purposive interpretations of the past," Professor Howe charged, "the Court has dishonored the arts of the historian and degraded the talents of the lawyer. "\$60 Howe's rebuke, it appears, had no effect whatsoever. The Court went on as before. If it did not actually continue to recite the same bad history, then it cited earlier cases that themselves recited that history. ${ }^{361}$ Some, perhaps most, of the justices

${ }^{357}$ I have in an earlier article advocated an "institutional separation" construction of the Establishment Clause. See Smith, supra note 142. Although the article's interpretation of the "original understanding" has been criticized, see Douglas Laycock, Original Intent and the Constitution Today, in THE FIRST FREEDOM: RELIGION AND THE BILL OF RIGHTS 87-112 (James E. Wood, Jr. ed., 1990), I continue to believe that the "institutional separation" construction is more attractive, on both "originalist" and "nonoriginalist" grounds, than either the prevailing doctrine or its leading competitors, including the "no preference," "no endorsement," and "coercion" tests. However, given the already considerable length of this Article, and under the temporary influence of my colleague Pierre Schlag's arguments regarding the futility of normative legal scholarship, see Pierre Schlag, Normativity and the Politics of Form, 39 U. PA. L. REV. 801 (1991); Pierre Schlag, Normative and Nowhere to Go, 43 STAN. L. REV. 167 (1990), I refrain from developing any specific prescription here.

${ }^{358} 330$ U.S. 1 (1947).

${ }^{359}$ See supra notes $34-38$ and accompanying text.

360 Howe, supra note 34 , at 4 .

361 A recent study offers an assessment of the Court's use of history that is almost identical to the one Howe gave a quarter century earlier: "The Court's habit of 
have expressed doubts about the Court's interpretation of religious freedom. ${ }^{362}$ But the Court seems powerless to change its course.

Although a reorientation of constitutional discourse remains possible, therefore, one can hardly feel very hopeful about the prospect. Even so, there is another optimistic observation-one implicit in the last three words of the title of this Article. Our current constitutional discourse cannot adequately justify religious freedom, perhaps, and the constitutional protection of religious freedom is accordingly in a process of deterioration. It does not follow, however, that religious freedom itself is doomed. Religious freedom may still receive indirect constitutional protection under other headings, such as speech, association, and equality. ${ }^{363}$ In addition, despite the deterioration of the constitutional commitment to religious freedom, religion remains eligible for protection by

selectively and sporadically invoking historical arguments to bolster its interpretation of the religion clauses has distorted the historical data and diluted the Court's arguments." Witte, supra note 33, at 506.

${ }^{362}$ See, e.g., County of Allegheny v. ACLU, 492 U.S. 573, 655 (1989) (Kennedy, J., concurring in part and dissenting in part); Edwards v. Aguillard, 482 U.S. 578, 636-40 (1987) (Scalia, J., dissenting); Wallace v. Jaffree, 472 U.S. 38, 108-13 (1985) (Rehnquist, J., dissenting); Lynch v. Donnelly, 465 U.S. 668, 687-94 (1984) (O'Connor, J., concurring) (proposing "no endorsement" test as a "clarification" of existing doctrine); Roemer v. Board of Pub. Works, 426 U.S. 736, 767-69 (1976) (White, J., concurring). Even Justice Brennan, in recent years perhaps the strongest defender and most aggressive enforcer of the prevailing standard (as set forth in Lemon v. Kurtzman, 403 U.S. 602, 612-13 (1971)), hinted that this test did not represent his doctrinal preference. In Lynch v. Donnelly, 465 U.S. 668 (1984), while employing the Lemon test, Justice Brennan suggested in a footnote that he was still attracted to a different test that he had proposed two decades earlier. See id. at $704 \mathrm{n} .9$ (Brennan, J., dissenting). Justices Marshall, Blackmun, and Stevens joined in Justice Brennan's Lynch opinion.

${ }^{363}$ Proposals to collapse the commitment to religious freedom into other values such as freedom of speech, freedom of association, and equal protection have proliferated. See, e.g., David K. DeWolf, State Action Under the Religion Clauses: Neutral in Result or Neutral in Treatment?, 24 U. RrCH. L. REv. 253 (1990) (advocating Philip Kurland's version of neutrality, which understands the religion clauses to be a kind of equal protection provision); Lupu, supra note 211 (arguing that institutional free exercise rights should be viewed as merely an application of freedom of association); Lupu, supra note 140 (proposing that religious freedom be understood in terms of equal protection); Marshall, supra note 10 (advocating that free exercise law be collapsed into free speech doctrine); Paulsen, supra note 245 (similar proposal); Tushnet, supra note 351 (advocating Philip Kurland's version of neutrality); Paul J. Weber, Neutrality and the First Amendment, in EQUAL SEPARATION, supra note 14, at 113 (similar proposal). This development supports the general argument of this Article: as the commitment to religious liberty becomes increasingly difficult to justify in contemporary discourse, scholars naturally seek to defend the commitment on the basis of what they regard as more comprehensible constitutional values. 
other institutions-in particular, by the institutions of democratic politics. The Court said as much in Smith. ${ }^{364}$

This situation need not evoke despair. There is a long-standing tradition, The Federalist No. 10 being the authoritative expression, of locating the principal barrier against overreaching government in the dynamic, conflictual course of pluralist politics. This analysis can readily be applied, and has been applied, to the issue of religious freedom: the diversity of religious faiths makes it unlikely that political institutions will attempt a wholesale restriction of religious freedom, even if the restraints imposed by courts are removed. ${ }^{365}$ Indeed, in view of the clumsiness of the courts' efforts in this area, a judicial withdrawal from the field conceivably might leave religious freedom in healthier condition.

Nonetheless, the decline in the constitutional commitment to religious freedom will have consequences, both practical and symbolic, which those who regard religious freedom as a fundamental value must regard as unfortunate. The constitutional protection of speech, association, and equality does not extend to embrace all that is afforded by rights to religious freedom. And even if pluralist politics provides adequate protection for most faiths, peripheral or unpopular religious groups are unlikely to find much help, ${ }^{366}$ as our history in this regard amply demonstrates. ${ }^{367}$

The symbolic consequence will be the loss of our historic commitment to religious freedom as a centerpiece of our constitutional order. The subordination of that commitment to other principles such as freedom of speech or equal protection and, more generally, to majoritarian politics, represents a kind of constitutional transvaluation of values. To those who accept Jefferson's statement that "the constitutional freedom of religion" is the "most inalienable and sacred of all human rights," 368 the reordering of our constitutional discourse is a troubling transformation.

${ }^{364}$ See Smith, 110 S. Ct. at 1606.

365 For a forceful argument that religious liberty has always depended primarily on politics and religious pluralism, not on any constitutional philosophy of religious freedom, see generally Bradley, supra note 55.

${ }^{366}$ See Laycock, supra note 339 , at 1014-16.

367 See supra note 241.

${ }^{368}$ See Jefferson, supra note 11 , at 958 . 